\begin{abstract}
UNIVERSIDADE DE SÃO PAULO
INSTITUTO DE RELAÇÕES INTERNACIONAIS

PROGRAMA DE PÓS-GRADUAÇÃO EM RELAÇÕES INTERNACIONAIS
\end{abstract}

Rafael Lopez Andreotti

EFEITOS DA REGULAÇÃO SOBRE O SETOR DE MICROFINANÇAS: APONTAMENTOS SOBRE OS CASOS DE BRASIL E MÉXICO

São Paulo 2018 


\title{
EFEITOS DA REGULAÇÃO SOBRE O SETOR DE MICROFINANÇAS: APONTAMENTOS SOBRE OS CASOS DE BRASIL E MÉXICO
}

\author{
Dissertação apresentada ao Programa \\ de Pós-Graduação em Relações \\ Internacionais do Instituto de Relações \\ Internacionais da Universidade de São \\ Paulo, para a obtenção do título de \\ Mestre em Ciências.
}

Orientadora: Prof $^{a}$. Dr ${ }^{\mathrm{a}}$. Adriana Schor

Versão corrigida

A versão original se encontra disponível na Biblioteca do Instituto de Relações Internacionais

São Paulo

2018 
Autorizo a reprodução e divulgação total ou parcial deste trabalho, por qualquer meio convencional ou eletrônico, para fins de estudo e pesquisa, desde que citada a fonte.

\section{FICHA CATALOGRÁFICA}

Andreotti, Rafael Lopez

Efeitos da regulação sobre o setor de microfinanças: apontamentos sobre os casos de Brasil e México / Rafael Lopez Andreotti ; orientadora: Adriana Schor. -- São Paulo, 2018.

$124 \mathrm{p}$.

Dissertação (Mestrado) - Instituto de Relações Internacionais. Universidade de São Paulo, São Paulo, 2018.

1. Microfinanças 2. Microcrédito 3. Regulação financeira I. Schor, Adriana, orient. II. Título.

$$
\mathrm{CDD}-332.742
$$




\title{
RESUMO
}

A presente pesquisa busca analisar os efeitos da regulação financeira sobre diferentes aspectos do setor de microfinanças. Para tanto identifica, a partir da literatura especializada, hipóteses que apontam para quatro variáveis como as mais sensíveis aos efeitos da regulação e supervisão. São elas a sustentabilidade financeira das instituições, seu alcance em relação ao número de clientes e do nível de renda deste, a adimplência observada em seus portfólios e a estrutura do setor de microfinanças em termos da quantidade e dos tipos de instituições existentes. Argumenta-se que cada elemento da regulação possui um efeito distinto sobre um ou mais desses aspectos, que são colocados à prova em dois estudos de caso. O primeiro é o caso brasileiro, no qual a evolução da regulamentação parece ter favorecido, até certo ponto, o predomínio de instituições públicas e no setor de microcrédito. Por sua vez, a regulamentação mexicana teria atuado no sentido oposto, favorecendo a formação de um grande número de instituições privadas, muitas das quais de pequeno porte.

Palavras-Chave: Microfinanças, Microcrédito, Regulação Financeira.

\begin{abstract}
This research aims at analyzing the effects of financial regulation over different aspects of the microfinance sector. Therefore, at first it identifies on the specialized literature hypothesis that point to four variables considered more sensible to the effects of financial regulation and supervision. Those are the financial sustainability of institutions, their outreach in terms of breadth as well as depth, the levels of loan losses in their portfolios and the very own structure of the microfinance sector regarding the quantity and the types of existing institutions. We argue that each aspect of financial regulation presents distinct effects over the variables above, and we put them to test by employing two case studies. The first focuses on Brazil, where the regulatory evolution appears to have benefited, up to a certain point, the dominance of public institutions on the microfinance sector. On the other hand, we look at the Mexican case, where we can find a great number of small sized private institutions. Therefore, financial regulation seems to have had so far the opposite effect it had in Brazil.
\end{abstract}

Keywords: Microfinance, Microcredit, Financial Regulation 


\section{Sumário}

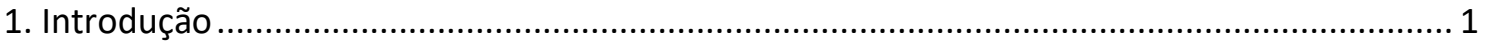

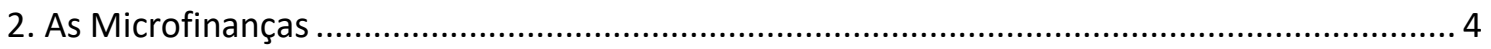

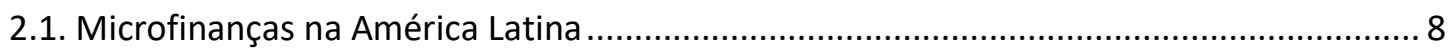

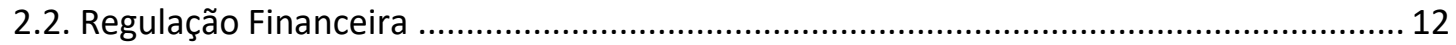

2.3. Microfinanças - As Razões para a Regulação ............................................................ 14

2.4. Regulação e Supervisão Financeira - Efeitos sobre as Microfinanças ............................... 19

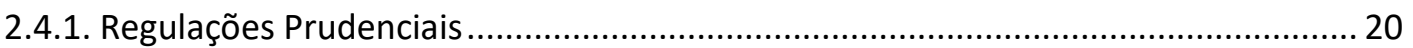

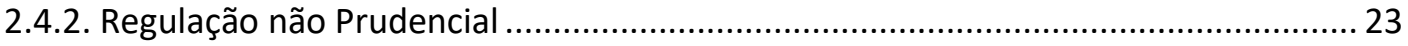

2.4.3. Upgrading, Downscaling e Competição …………………………………............. 27

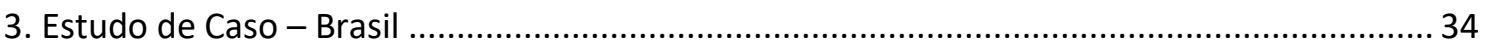

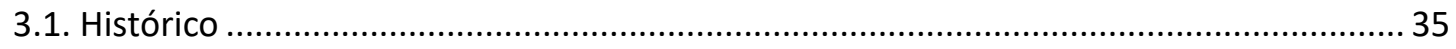

3.2. Regulamentação das Microfinanças no Brasil ............................................................. 41

3.2.1. ONGs e Organizações da Sociedade Civil de Interesse Público................................... 41

3.2.2. Sociedades de Crédito ao Microempreendedor e à Empresa de Pequeno Porte

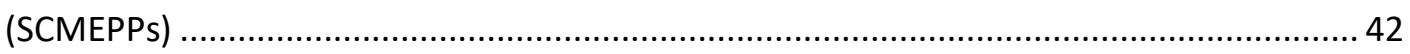

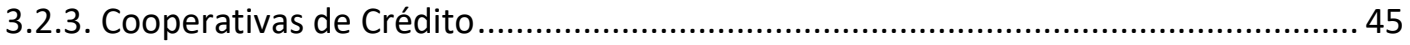

3.2.4 Direcionamento de Recursos às Microfinanças ......................................................... 52

3.2.5. Programa Nacional de Microcrédito Produtivo Orientado ........................................ 55

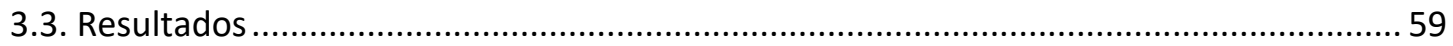

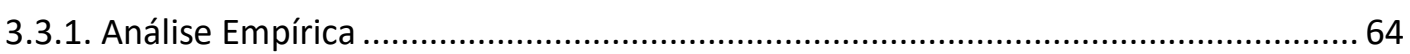

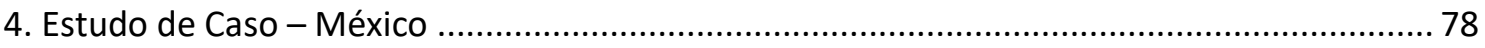

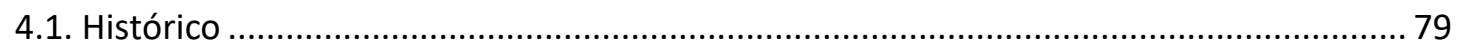

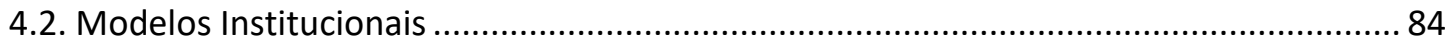

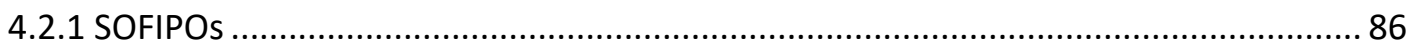

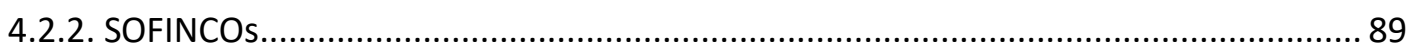

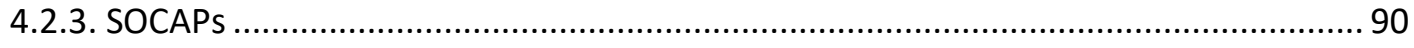

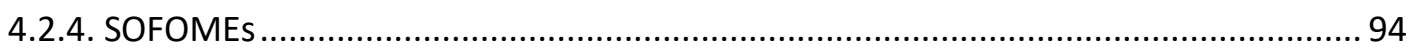

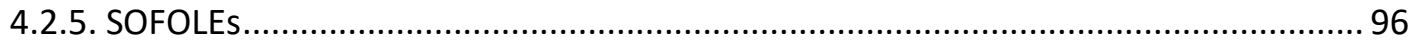

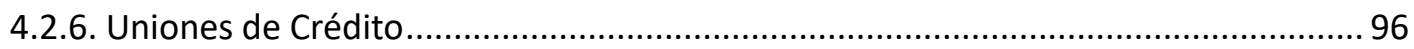


5. Considerações Finais 110

6. Referências. 


\section{Introdução}

$\mathrm{O}$ atual movimento de microfinanças teve seu início a partir das iniciativas pioneiras conduzidas ainda na década de 1970 em países como Brasil e, em especial, Bangladesh, com o caso bastante conhecido do Grameen Bank e de seu fundador Muhammad Yunus, vencedores do Prêmio Nobel da Paz no ano de 2006. Na década de 1980, as microfinanças foram marcadas por experiências como a do Banco Rakyat Indonésia, que demonstraram o potencial existente para que instituições atuantes no setor atingissem simultaneamente objetivos de ganhos de escala em termos de clientela atendida e de manutenção da sustentabilidade financeira. Nos anos 1990, o setor passou por uma transformação significativa, com a redução da dependência de doações e a adoção de uma visão mais comercial, inclusive com a participação de atores como bancos comerciais. Em paralelo ao envolvimento de instituições de mercado no setor, muitas autoridades governamentais passaram a encarar as microfinanças como ferramentas de desenvolvimento, capazes de ampliar o acesso a serviços financeiros aos indivíduos deles excluídos.

Nesse contexto, a melhor compreensão da regulamentação das microfinanças ganha especial importância, dadas as possibilidades de sua inserção como parte de estratégias cujo objetivo é a promoção da inclusão financeira, do desenvolvimento econômico e social e mesmo da redução da pobreza. Um indício da importância assumida pela regulamentação é o fato de diversas instituições internacionais estarem se dedicando à definição de princípios e padrões relativos a regulação e supervisão financeiras, muitas vezes ligadas às microfinanças. É o caso do Consultative Group to Assist the Poor (CGAP), tanto no âmbito de sua atuação junto ao G-20 Global Partnership for Financial Inclusion (GPFI), quanto na publicação de seu Guia para Regulação e Supervisão das Microfinanças, lançado no ano de 2012.

O foco do presente trabalho recai justamente sobre a forma como a regulamentação financeira afeta os diferentes aspectos do setor de microfinanças, buscando responder as seguintes perguntas de pesquisa: i) a regulação e a supervisão financeira realmente possuem efeitos sobre o setor de microfinanças? ii) quais são esses efeitos? iii) quais os mecanismos pelos quais a regulação e a supervisão produzem tais efeitos?

Partindo da hipótese de que a regulação e a supervisão de fato afetam aspectos distintos do setor de microfinanças, sendo, portanto, mecanismos relevantes para o 
planejamento e condução de políticas públicas, foi conduzido inicialmente um estudo exploratório, de modo a identificar variáveis e mecanismos que serviriam de enfoque para a análise. A literatura aponta para quatro elementos-chave como variáveis dependentes, sendo eles: o alcance a clientes em suas dimensões de quantidade (amplitude) e de acesso a clientela mais vulnerável (profundidade); a sustentabilidade financeira das instituições, ou seja, sua capacidade de financiar suas operações e promover seu desenvolvimento com os recursos disponíveis; adimplência de portfólios de microcrédito; e estrutura do setor em termos de tipos e quantidade de instituições atuantes.

Quantos aos tipos de regulação e de supervisão que podem ser considerados variáveis independentes, é possível fazer a distinção entre os prudenciais, cujos objetivos principais são a garantia da solidez do sistema financeiro e a proteção dos recursos de seus clientes, e os não prudenciais, cujo foco é a garantia da eficiência, bom funcionamento e qualidade dos serviços oferecidos no mercado (ROSENGARD, 2011: pp.161-162). Dentre os elementos destacados como possuindo efeitos sobre o setor de microfinanças encontram-se disposições de adequação de capital e de taxas de provisão contra inadimplência, limites de juros, exigências de capital de entrada, entre outros. A existência de estruturas escalonadas de regulação e os processos de transformação e de downscaling realizados por muitas instituições são outros elementos discutidos abaixo.

Outrossim, os mecanismos pelos quais esses tipos de regulação afetariam as microfinanças são diversos e discutidos em profundidade abaixo. Para colocá-los à prova, optou-se pela realização de dois estudos de caso, tendo sido selecionados os casos de Brasil e México. A escolha tomou como base o fato de se tratarem de duas das maiores economias da América Latina, com setores de microfinanças relativamente novos e que têm empregado nos últimos anos esforços no sentido sua regulamentação e promoção, embora com enfoques diferentes. Enquanto no caso brasileiro destaca-se atuação do Programa Crediamigo do Banco do Nordeste, instituição pública, a instituição com maior peso no caso mexicano é o Banco Compartamos, instituição que passou de uma organização sem fins lucrativos, para um banco múltiplo nos últimos anos. Esses dois bancos, duas das maiores instituições envolvidas com microfinanças na América Latina, são até certo ponto representativos do maior ou menor peso dos setores público e privado no setor de microfinanças de ambos os países. 
À luz das hipóteses e variáveis identificadas na literatura, buscou-se colher e analisar os principais dispositivos regulamentares em vigor, resultando nos efeitos esperados da regulação em cada país. Por fim, partiu-se para o estudo dos dados empíricos de cada caso, sendo possível assim ponderar a respeito da validade das hipóteses previamente levantadas.

A despeito da existência de bancos de dados internacionais referentes às microfinanças, optou-se pelo emprego de dados de fontes oficiais internas de cada país, em tese mais abrangentes em termos de instituições abarcadas, embora não despidas de problemas. Para o caso brasileiro, foram utilizados dados do Banco Central do Brasil sobre a Evolução do Sistema Financeiro e relatórios do Programa Nacional de Microcrédito Produtivo e Orientado, produzidos pelo Ministério do Trabalho e do Emprego, neste caso com algumas inconsistências devido, principalmente, à mudança de seu formato e das informações por eles apresentadas ao longo dos anos. Enquanto a análise da legislação possibilita identificar certo tipo de evolução temporal para a realização de uma análise mais robusta, os dados empíricos sobre microfinanças no Brasil ainda são limitados e de difícil acesso, fornecendo poucas informações a respeito de variáveis como autossustentabilidade financeira e profundidade do alcance.

Por sua vez, o caso mexicano apresenta maiores dificuldades em relação ao levantamento de legislação específica versando sobre microfinanças, sendo a análise baseada nos compilados oficiais denominados Disposiciones de Carácter General. Para tanto, optou-se pelo enfoque nos principais modelos institucionais atuantes no setor, ainda que em alguns casos não trabalhem exclusivamente com microfinanças, e tal separação nem sempre exista nos dados empíricos empregados. Estes, por sua vez, foram colhidos a partir dos Boletins de Estatísticos divulgados pela Comisión Nacional Bancaria y de Valores (CNBV), que possibilitam uma análise da evolução de cada modelo ao longo do tempo em relação às variáveis elencadas. No entanto, são dados autorreportados. Apesar de contarem com a avaliação e parametrização da Comisión, apresentam certas inconsistências relativas a instituições que deixam de reportar com a periodicidade exigida, por exemplo.

A despeito do uso do termo microfinanças até o presente momento, o enfoque do presente trabalho recai principalmente sobre o microcrédito, por necessidade de recorte de enfoque e de limitações dos dados empíricos disponíveis para os casos analisados. Ambos os termos são definidos no início do próximo capítulo, embora seja seguido o 
exemplo da literatura discutida e mantido o uso, em muitos momentos, do termo microfinanças para tratar dos potenciais efeitos da regulação e supervisão. Da mesma forma, muitas das variáveis independentes discutidas no capítulo teórico são mecanismos de regulação existentes para o sistema financeiro como um todo. Nesses casos, o foco da discussão é sobre seus efeitos sobre o objeto aqui discutido.

Enfim, é importante ressaltar que o enfoque do presente trabalho recai no debate acerca dos efeitos da regulação e da supervisão sobre as microfinanças e, mais especificamente, sobre o microcrédito. Obviamente, tais elementos não existem no "vácuo", e são afetados por desenvolvimentos políticos, econômicos e sociais. Entretanto, buscou-se ao máximo isolar tais variáveis de forma a melhor compreender seus efeitos, ainda que se trate de uma tarefa ingrata e nem sempre possível.

Após esta breve introdução, o primeiro capítulo aborda o referencial teórico relativo aos efeitos da regulação e da supervisão financeira sobre o setor de microfinanças. O segundo capítulo consiste no estudo do caso brasileiro, enquanto o terceiro discute o caso mexicano. A última seção é destinada às considerações finais.

\section{As Microfinanças}

Microfinanças podem ser consideradas serviços financeiros voltados para a população de baixa renda, geralmente excluída do sistema financeiro tradicional, que apresentam produtos, gestão e processos diferenciados (ALVES e SOARES, 2006: p.28). Elas envolvem atividades como micropoupanças, microsseguros e microcrédito, modalidade mais reconhecida e disseminada e que pode ser definida de modo mais abrangente como "empréstimo de baixo valor concedido a pessoas de baixa renda" (NERI, 2008: p.29). Porém, cabe ressaltar que muitos países apresentam definições legais específicas, adequadas a seu contexto doméstico.

O setor de microfinanças é formado por tipos institucionais diversos, com diferentes configurações jurídicas. Tchakoute-Tchuigoua (2010, p.437) identifica quatro tipos de instituições de microfinanças (IMFs), diferenciando-as com base em seu status legal (Figura 1). O primeiro é composto por bancos comerciais e instituições financeiras do setor bancário tradicional que optam por adentrar no setor de microfinanças, estratégia denominada downscaling e abordada abaixo. $\mathrm{O}$ segundo tipo institucional apresentado pelo autor é o de bancos comerciais e instituições financeiras especializadas exclusivamente em microfinanças. Apesar da distinção, instituições pertencentes a esses 
dois grupos são legalmente estruturadas como companhias privadas ou companhias de capital aberto (shareholders firms -SHF). O autor identifica ainda outras duas categorias, cada uma correspondente a um status legal particular. A primeira é composta por cooperativas de crédito, e classificada como cooperativas de crédito e organizações mutuais. A outra diz respeito a organizações não governamentais (ONGs), configuradas juridicamente como organizações sem fins lucrativos.

\begin{tabular}{|c|c|}
\hline Tipo Institucional & Configuração Jurídica \\
\hline $\begin{array}{c}\text { Bancos Comerciais e Instituições Financeiras } \\
\text { engajados em estratégias de downscaling }\end{array}$ & Companhias Privadas ou Companhias de Capital \\
\cline { 1 - 1 } $\begin{array}{c}\text { Bancos Comerciais e Instituições Financeiras } \\
\text { especializadas em microfinanças }\end{array}$ & Aberto (SHF) \\
\hline Cooperativas de Crédito & Cooperativas de Crédito e Organizações Mutuais \\
\hline Organizações Não Governamentais (ONGs) & Organizações sem Fins Lucrativos \\
\hline
\end{tabular}

Figura 1. Tipos Institucionais e suas Configurações Jurídicas - Setor de Microfinanças

Fonte: TCHAKOUTE-TCHUIGOUA, H. Is There a Difference in Performance by the Legal Status of Microfinance Institutions? The Quarterly Review of Economics and Finance 50, 2010. p. 437.

Os status jurídicos correspondentes aos tipos institucionais atuantes no setor implicam em estruturas de governança e de propriedade específicas, que dão origem a problemas de agência e regulação próprios. Entretanto, a atuação dessas diferentes instituições no mercado de microfinanças também apresenta desafios comuns, diretamente relacionados às características dos clientes e das operações financeiras a eles adaptadas. Nesse sentido, restrições de acesso a serviços financeiros em geral, e ao crédito em particular, por indivíduos de baixa renda têm suas origens nos altos custos unitários de operações de pequenos valores quando comparadas àquelas de montantes mais elevados. Outros fatores que influem nesse acesso limitado a operações tradicionais de crédito são os riscos associados à falta de colateral formal, à assimetria de informações entre instituição e cliente e às dificuldades de monitoramento dos recursos cedidos (NERI, 2008: p.35).

$\mathrm{O}$ atual movimento de microfinanças tem suas origens na vertente moderna de microcrédito (GUINNANE, 2011), desenvolvida a partir da década de 1970 por iniciativas pioneiras como o futuro Grameen Bank, em Bangladesh, e o Projeto UNO (União Nordestina de Assistência a Pequenas Organizações), no Brasil. O contexto era 
de fortalecimento do pensamento neoliberal em países como Estados Unidos e Reino Unido e nas instituições de Bretton Woods (CHOWDHURY, 2009: p.7). A visão do microcrédito como promotor de pequenos empreendimentos formais e informais e do autoemprego $^{1}$, em especial para indivíduos menos qualificados, constituindo uma alternativa ao papel preponderante do Estado no processo de desenvolvimento econômico (CACCIAMALI et al, 2008: p.151), teria apresentado apelo particular nesses países e instituições. Receosos acerca de programas estatais de crédito subsidiado, eles teriam se engajado na promoção de instituições (privadas) de microfinanças em países em desenvolvimento, tendo como objetivo a consolidação da economia de mercado e a redução do papel governamental no processo de desenvolvimento econômico.

Em parte devido ao fomento de agências governamentais e ONGs de países desenvolvidos, além de instituições internacionais, o movimento de microfinanças apresentou grande expansão ao redor do mundo. A partir da década de 1980, experiências como as do Banco Rakyat Indonésia (BRI) e da Associación para el Desarrollo de la Microempresa (Ademi), na República Dominicana, comprovaram o potencial de IMFs atingirem escala e sustentabilidade financeira. Desenvolveu-se uma nova perspectiva das microfinanças, mais ligada a objetivos financeiros, segundo a qual a dependência de subsídios restringia o escopo e potencial de crescimento do setor aos recursos disponibilizados por doadores, muitas vezes limitados. Embora doadores internacionais tenham se mantido envolvidos no setor de forma significativa, muitas instituições passaram a buscar novas fontes de funding, como empréstimos comerciais e captação de depósitos do público (ASSUMPÇÃO et al, 2004: p.94).

A partir da década de 1990, essa perspectiva de redução da dependência de doadores desembocou em dois processos distintos, porém relacionados, que influenciaram de modo significativo o setor desde então (VANROOSE e D’ESPALLIER, 2009: p.5). O primeiro desses processos é a comercialização das microfinanças, que consiste na visão da atividade de venda de serviços financeiros a indivíduos de baixa renda como uma estratégia de mercado (ASSUMPÇÃO et al, 2004: p.101) e tem como um de seus principais aspectos a busca pela obtenção de lucros.

\footnotetext{
${ }^{1}$ Entretanto, muitos estudos apresentam poucas evidências acerca desse efeito positivo das microfinanças sobre a criação de emprego, embora outras correlações desejadas como redução do subemprego e manutenção de postos de trabalho tenham sido encontradas (CACCIAMALI et al, 2008: p.157-158).
} 
Nesse sentido, casos de instituições que conseguiram se tornar rentáveis atraíram novas instituições e atores para o setor, resultando em uma maior competição por clientes. Finalmente, a comercialização das microfinanças resultou também em maior regulação, seja por iniciativa de autoridades governamentais ou por pressões de atores envolvidos no setor (CHRISTEN, 2001: p.2).

Por sua vez, o processo de transformação está ligado a essa tendência crescente de regulação do setor. Também conhecido como upgrading, envolve a formação de uma instituição regulada a partir de uma ou mais organizações sem fins lucrativos, com transferência completa ou parcial de seus portfólios de empréstimo (FERNANDO, 2004: p.2). Muitas ONGs fizeram a opção pela transformação devido a regulação ser, em diversos países, um requisito prévio à obtenção de acesso a mercados financeiros e outras formas de financiamento, bem como ao oferecimento de novos tipos de serviços (GALLARDO, 2001: p.4). Nesse sentido, destaca-se a aceitação e intermediação de depósitos, atendendo tanto à necessidade de IMFs por recursos quanto à demanda de clientes por esse serviço (FERNANDO, 2004: pp.4-5). Para além, regulação pode trazer maior legitimidade para as operações de IMFs (MENDOZA e VICK, 2010: pp. 564$565)$.

Oposto ao upgrading está o processo de downscaling, envolvendo bancos e outras instituições financeiras previamente reguladas que fazem a opção por atuar no mercado de microfinanças. Destarte, aproveitam seu maior acesso a financiamento comercial e fazem uso da infraestrutura de agências de atendimento muitas vezes disponível para ampliar o alcance dos serviços oferecidos a clientes de menor renda e microempresas. Abordagens comuns por parte de bancos são o desenvolvimento de parcerias com organizações sem fins lucrativos ou a criação de novas subsidiárias para operarem seus programas de microfinanças (ROSALES, 2006: p.119).

Enquanto muitos bancos comerciais foram atraídos para o setor a partir dos processos de mudança iniciados na década de 1990, governos passaram a incentivar as microfinanças a partir de sua interpretação como política pública com potencial para impactar o nível de vida material de indivíduos de menor renda (CACCIAMALI et al, 2008: p.150). Em muitos países, bancos públicos obtiveram sucesso na construção de amplas bases de clientes, demonstrando que o processo de comercialização não se restringia unicamente à atuação de agentes privados voltados para fins unicamente lucrativos (ASSUMPÇÃO et al, 2004: p.119). Atualmente, as microfinanças são 
encaradas como uma ferramenta mais abrangente de desenvolvimento, voltada para expandir o acesso a serviços financeiros aos excluídos de países emergentes e mercados em desenvolvimento (LUTZENKIRCHEN et al, 2012: p.3).

\subsection{Microfinanças na América Latina}

Embora seja possível traçar o histórico das microfinanças em termos gerais, seu desenvolvimento se deu de forma desigual entre diferentes regiões e países, resultando em trajetórias e modelos distintos. A despeito de variações inclusive no interior de países, Berger (2006, p.4) aponta para o que pode ser considerado um modelo latinoamericano de microfinanças, com padrões e tendências gerais na indústria da região.

Reformas do setor financeiro nas décadas de 1980 e 1990 na América Latina, incluindo a adoção de novas leis bancárias e de mercados de capitais (JANSSON e WENNER, 1998: p.8), contribuíram para a entrada de novos atores e para a ampliação do escopo de clientes do sistema financeiro como um todo. As medidas resultantes reduziram sensivelmente a repressão financeira vigente sob a forma de políticas de alocação de crédito, tetos de juros e barreiras de entrada a novas instituições, entre outras (CUEVAS, 1996: pp. 197-198). Embora não tenham sido direcionadas especificamente ao segmento de microfinanças, contribuíram de modo significativo para a manutenção do modelo de negócios e expansão do setor (ROSALES, 2006: p. 117).

O movimento de microfinanças na América Latina concentrou-se, em um primeiro momento, em organizações sem fins lucrativos, partindo de fundos limitados para cobrir despesas operacionais e estabelecer carteiras de crédito (CHRISTEN, 2012: p.8). Essas IMFs eram voltadas majoritariamente para mercados urbanos e focadas no fornecimento de microcrédito a empresas de pequeno porte e a indivíduos com acesso restrito a serviços financeiros. Diferentes metodologias de crédito foram empregadas nos portfólios de microcrédito da região, como grupos de solidariedade, banca comunal, empréstimos individuais ou técnicas mistas (CHRISTEN, 2012: p.10). Por sua vez, a ampliação dos produtos financeiros oferecidos, em parte como consequência da maior competição (MENDOZA e VICK, 2010: pp. 558-559), ocorreu paulatinamente, englobando diferentes modalidades de crédito, contas de depósitos e poupança e microsseguros. Contudo, microcrédito ainda constitui a maior proporção dos produtos de microfinanças, em alguns países devido a restrições legais quanto a aceitação de depósitos por instituições não reguladas. 
A expansão dos produtos oferecidos e da carteira de clientes foram dois fatores que culminaram na atração de recursos privados para o setor, envolvendo investidores como fundos de pensão, bancos de investimento e fundos internacionais de capital para o desenvolvimento (BERGER, 2006: p.7). Assim, em termos gerais, IMFs latinoamericanas apresentam uma tendência a financiar suas atividades e sua expansão a partir de empréstimos provenientes de fontes comerciais e de equity. Como resultado, a dependência de doadores tem diminuído.

$\mathrm{O}$ setor de microfinanças na América Latina, dominado quase que exclusivamente por ONGs e sociedades cooperativas no início da década de 1990, teve seu ambiente institucional alterado significativamente ao longo dos anos seguintes (CHRISTEN, 2001: p.1). Diversas instituições sem fins lucrativos optaram pelo processo de upgrading, com algumas delas se transformando nas instituições bancárias de grande porte atuantes no segmento de microfinanças latino-americano atualmente. Em diferentes países, o sucesso dessas instituições atraiu novos atores para a indústria, como cooperativas de crédito, companhias financeiras de propósito especial, bancos múltiplos, bancos comerciais especializados e bancos comerciais públicos (BERGER, 2006: p.13).

Embora a América Latina seja considerada a região em que IMFs mais aderiram aos processos de comercialização e de transformação (ASSUMPÇÃO et al, 2004: p.112), dados compilados por Trujillo $(2013$, p.8) apontam para um relativo predomínio de bancos e outras instituições financeiras entre as entidades reguladas que operam microfinanças na região e no Caribe, evidenciando a força adquirida pela estratégia de downscaling. Conforme observado na Tabela 1, em 2012, as instituições batizadas pelo autor como downscales correspondiam a 211 de um total de 449 entidades reguladas atuantes no segmento, enquanto as instituições que haviam passado pelo processo de upgrading somavam 61.

De uma carteira total de US\$ 33.727.465.695,00 das instituições reguladas da região, as downscales eram responsáveis por US\$25.236.198.792,00, aproximadamente dois terços. Em contrapartida, eram responsáveis por pouco menos da metade dos clientes, com 6.986.766 de um total de 13.262.865. Em comparação, instituições transformadas apresentavam 5.981.178 clientes, uma diferença de pouco menos de 1 milhão, embora seu portfólio de crédito totalizasse US\$7.285.074.804,00. Essa diferença de carteira total, desproporcional quando comparada à diferença de clientes, 
pode ser explicada pelos valores médios de microcrédito concedidos por cada grupo: US\$3.612,00 no caso das downscales, frente a US\$1.218,00 das instituições transformadas. Cooperativas de crédito correspondiam a 177 instituições reguladas, com carteira de crédito total de US\$1.209.765.942,00, 294.921 clientes e valor médio de crédito equivalente a US\$4.102,00.

\begin{tabular}{|c|c|c|c|c|}
\hline Categorias & $\begin{array}{c}\text { Carteira de } \\
\text { Crédito (US\$) }\end{array}$ & $\begin{array}{c}\text { Clientes de } \\
\text { Microcrédito }\end{array}$ & $\begin{array}{c}\text { Valor Médio de } \\
\text { Crédito (US\$) }\end{array}$ & $\begin{array}{c}\text { Número de } \\
\text { Instituições }\end{array}$ \\
\hline $\begin{array}{c}\text { Bancos } \\
\text { (Downscaling) }\end{array}$ & 25.236 .198 .792 & 6.986 .766 & 3.612 & 211 \\
\hline $\begin{array}{c}\text { Instituições } \\
\text { Transformadas } \\
\text { (Upgrading) }\end{array}$ & 7.285 .074 .804 & 5.981 .178 & 1.218 & 61 \\
\hline $\begin{array}{c}\text { Cooperativas de } \\
\text { Crédito }\end{array}$ & 1.209 .765 .942 & 294.921 & 4.102 & 477 \\
\hline Total & 33.727 .465 .695 & 13.262 .865 & 2543 & \\
\hline
\end{tabular}

Tabela 1. Carteira Total e Número de Clientes de Microcrédito de Instituições Reguladas na América Latina - 2012

Fonte: TRUJILLO, V. Microfinanzas en América Latina y el Caribe: el sector en cifras 2013. Washington, DC: Fondo Multilateral de Inversiones, 2013. p.8.

É possível observar na Tabela 2 que, no mesmo ano, haviam 645 instituições não reguladas atuando com microfinanças na América Latina e Caribe, distribuídas em 401 ONGs e 244 cooperativas de crédito. ONGs apresentavam carteira total de US\$4.373.529.237,00, atendendo 6.311 .009 clientes com um valor médio de empréstimo de US\$693,00. Cooperativas não reguladas, por sua vez, possuíam carteira de US\$1.248.752.718,00, com 516.654 clientes e empréstimo médio de US\$2.417,00.

\begin{tabular}{|c|c|c|c|c|}
\hline Categorias & $\begin{array}{c}\text { Carteira de } \\
\text { Crédito (US\$) }\end{array}$ & $\begin{array}{c}\text { Clientes de } \\
\text { Microcrédito }\end{array}$ & $\begin{array}{c}\text { Valor Médio de } \\
\text { Crédito (US\$) }\end{array}$ & $\begin{array}{c}\text { Número de } \\
\text { Instituições }\end{array}$ \\
\hline ONGs & 4.373 .529 .237 & 6.311 .009 & 693 & 401 \\
\hline $\begin{array}{c}\text { Cooperativas de } \\
\text { Crédito }\end{array}$ & 1.248 .752 .718 & 516.654 & 2.417 & 244 \\
\hline Total & 5.622 .281 .955 & 6.827 .663 & 823 & 645 \\
\hline
\end{tabular}

Tabela 2. Carteira Total e Número de Clientes de Microcrédito de Instituições Não Reguladas na América Latina - 2012 
Fonte: TRUJILlo, V. Microfinanzas en América Latina y el Caribe: el sector en cifras 2013. Washington, DC: Fondo Multilateral de Inversiones, 2013. p.8.

A comparação entre os dois status regulatórios apresenta alguns elementos de interesse. Enquanto o valor médio de crédito das instituições transformadas era praticamente o dobro daquele apresentado pelas ONGs, ele era o mais baixo entre as demais categorias. Trata-se de um possível indício da origem sem fins lucrativos dessas instituições. Por sua vez, ONGs e downscales atendiam um número bastante próximo e elevado de clientes, acima de 6 milhões cada, constituindo as principais categorias institucionais em termos de alcance a clientes. No entanto, a grande disparidade em seus valores médios de crédito aponta para o fornecimento de microcrédito a grupos distintos de indivíduos, com ONGs priorizando clientes mais vulneráveis e as downscale aqueles de maior renda. ONGs necessitam de quase o dobro de instituições para se aproximar do número de clientes atendidos pelas downscale, evidenciando sua tendência a serem instituições menores, com um número não tão alto de indivíduos atendidos (LUTZENKIRCHEN et al, 2012: p.4).

Além disso, o valor médio dos empréstimos concedidos por cooperativas reguladas era muito superior àquele de cooperativas não reguladas, talvez em decorrência dos próprios custos impostos pela regulação exigirem a concessão de crédito de maior valor e menores custos unitários. Em geral, cooperativas de crédito são instituições que fornecem serviços financeiros apenas a seus próprios associados, e muitas vezes são submetidas pelas autoridades nacionais somente a leis que regem o funcionamento geral de todos os tipos de cooperativas, não tendo suas atividades financeiras reguladas. Entretanto, conforme elas crescem, os laços que deveriam unir seus cooperados podem se enfraquecer, o que as tornaria instituições financeiras como quaisquer outras. Assim, na última década, esforços têm sido realizados por toda a região para acabar com esse vácuo regulatório existente para as cooperativas de crédito em muitos países (ROSALES, 2006: pp.133-134).

Trujillo (2013, p.8) também apresenta dados acerca da evolução do total de instituições de microcrédito na América Latina ao longo do tempo (Figura 2). Em 2001 existiam 184 instituições, número que passou para 336 em 2005, 565 em 2007 e se manteve entre 605 e 675 de 2008 a 2011. Em 2012 foram computadas 1094 instituições, sendo a ampliação de dados disponíveis sobre microcrédito certamente um fator nessa ampliação tão elevada. A despeito das limitações dos dados compilados e das 
disparidades do número de países incluídos na análise a cada ano, é possível afirmar que o setor de microfinanças na América Latina apresentou uma expansão significativa ao longo da década.

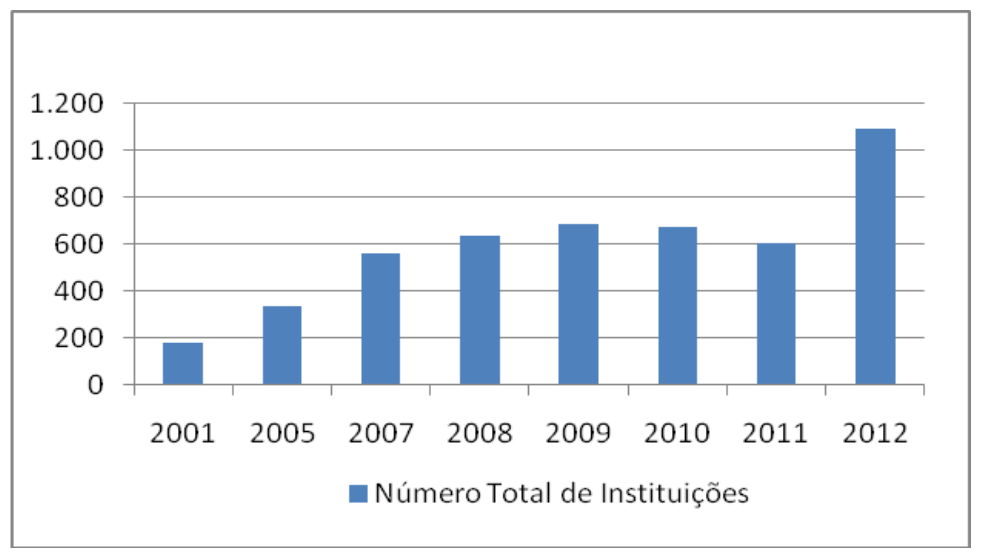

Figura 2. Evolução Temporal do Número de Instituições que Operam Microcrédito na América Latina - 2001/2012

Fonte: TRUJILlO, V. Microfinanzas en América Latina y el Caribe: el sector en cifras 2013. Washington, DC: Fondo Multilateral de Inversiones, 2013. p.8.

Em meio a gama institucional envolvida no setor, e apesar dos distintos ritmos de regulação financeira observados em cada país latino-americano (CUASQUER e MALDONADO, 2011: p.12), pressões para a inclusão das microfinanças no quadro regulatório financeiro mais amplo existem tanto com o intuito de proteger os clientes de microfinanças quanto garantir melhores condições em termos de financiamento, serviços e estrutura do setor como um todo.

\subsection{Regulação Financeira}

Segundo Rosengard (2011, p.161), regulação financeira consiste na definição dos padrões e na determinação das "regras do jogo" no setor. Supervisão, por outro lado, diz respeito ao monitoramento e enforcement da adequação de instituições a essas regras. Embora distintos, não podem ser dissociados.

Regulação financeira pode ser classificada de modo mais geral em prudencial e não prudencial, cada uma englobando elementos distintos, porém complementares. A regulação prudencial consiste em normas e regras cujos objetivos principais são a proteção da solidez do sistema financeiro como um todo, evitando que problemas em uma instituição se tornem sistêmicos, e a garantia de segurança dos recursos de pequenos depositantes em instituições individuais (CHRISTEN et al, 2003: p.3). Nesse 
sentido, abarca questões como adequação de capital, qualidade de ativos, provisões de liquidez e limites de concentração de riscos.

Por sua vez, a regulação não prudencial tem como foco assegurar a eficiência de mercado, tendo em vista garantir seu bom funcionamento e a qualidade dos serviços oferecidos (ROSENGARD, 2011: pp.161-162). Jansson e Werner apontam para a existência de cinco categorias não prudenciais de regulação. Controles macroeconômicos envolvem medidas capazes de alterar a atividade econômica em termos gerais, como exigências de reserva, controles de taxas de juros e restrições a investimentos externos. Controles alocativos visam influenciar a distribuição de recursos na economia através de programas seletivos de crédito, exigências compulsórias de investimentos e taxas preferenciais de juros. Controles estruturais incluem exigências de capital de entrada, diretrizes a respeito de fusões, restrições de atuação geográfica e limites a atividades de instituições financeiras, tendo em vista reger sobre a estrutura do sistema financeiro. Controles organizacionais envolvem regras de criação e de participação em mercados, divulgação de informações de mercado e padrões técnicos mínimos. Finalmente, controles de proteção incluem medidas como limites de juros, fundos de compensação e transparência dos serviços oferecidos, buscando proteger os clientes do sistema financeiro (JANSSON e WERNER, 1998: pp.11-12).

Assim, regulação não prudencial engloba elementos como proteção de consumidores, segurança de transações, prevenção de fraudes financeiras, criação de serviços de informação de crédito, limites de propriedade estrangeira, provisões para o desempenho de atividade financeira e limites de juros, entre outros. Na maioria dos países, disposições não prudenciais são aplicadas a instituições com e sem fins lucrativos atuantes no setor financeiro (ARMENDARIZ e MORDUCH, 2010: pp.258261).

A supervisão financeira também pode ser dividida em duas categorias complementares. A primeira delas envolve atividades de supervisão realizadas em visitas de campo à instituição financeira, cujos objetivos consistem na verificação interna de dados e na validação externa em termos de informações qualitativas sobre gerenciamento, clientes e condições de mercado. O segundo caso envolve as atividades realizadas fora das instituições financeiras supervisionadas, sobretudo a análise de relatórios por elas produzidos, com o intuito de avaliar sua saúde financeira e facilitar a 
identificação de potenciais problemas. Sua realização é mais frequente e contribui para a definição dos elementos que devem ser verificados em inspeções de campo (ROSENGARD, 2011: pp. 161-162).

\subsection{Microfinanças - As Razões para a Regulação}

Entre os desafios impostos pela atividade de intermediação financeira estão problemas de assimetria de informação, que ocorrem quando a instituição apresenta conhecimento limitado sobre seus clientes tanto antes quanto depois da concessão de crédito (GREMAUD e TONETO JR., 2002: p.89). Sua primeira manifestação se dá na avaliação da viabilidade econômica e dos riscos de um pedido de empréstimo feito por um cliente. As dificuldades de mensuração pelo banco dos reais riscos de cada proposta resultam em problemas de seleção adversa, em que os custos de transação são elevados pela necessidade de emprego de sistemas informacionais que visam a seleção de clientes com menores probabilidades de inadimplência. No mesmo sentido, configura-se um contexto de racionamento de crédito, com as propostas de maior potencial econômico nem sempre recebendo os empréstimos solicitados (CACCIAMALI et al, 2008: p.152).

Após a concessão de crédito, a existência de assimetria de informações gera ao banco problemas de risco moral (moral hazard) devido a incertezas quanto a capacidade do tomador honrar o crédito contraído e capacidade reduzida no monitoramento dos empréstimos concedidos. Desta forma, a instituição fica exposta ao comportamento oportunista de seus clientes ${ }^{2}$, cuja probabilidade de ocorrer aumenta quanto menores os custos (não somente econômicos) da inadimplência para os tomadores. Como forma de proteção, bancos tendem a empregar os sistemas de avaliação de risco tanto na seleção de seus clientes quanto no monitoramento dos empréstimos concedidos. Da mesma maneira, também exigem garantias de pagamento sob a forma de bens do tomador, o chamado colateral (CACCIAMALI et al, 2008: p.153).

Muitos indivíduos e microempresas acabam excluídos dos mercados tradicionais de crédito pela impossibilidade de atender aos requisitos impostos pelos bancos.

\footnotetext{
${ }^{2} \mathrm{O}$ oposto também é válido. Depositantes muitas vezes não se encontram em posição de monitorar ou influenciar a solidez financeira da instituição, podendo ter seus recursos colocados em risco (GALLARDO, 2001: p.5). Em contrapartida, acionistas possuem maior capacidade de influenciar o comportamento da instituição, o que pode resultar em maiores incentivos para a busca pela maximização dos lucros a partir de comportamentos de maior risco. Regulação e supervisão financeiras são importantes para proteger também os depositantes de problemas dessa natureza (JANSSON e WENNER, 1998: p.5).
} 
Conforme mencionado anteriormente, as microfinanças visam atender justamente essa parte da população, em geral de baixa renda e atuante no setor informal da economia. A concessão de crédito nessas condições muitas vezes exige adaptações que resultam em desafios específicos impostos pelas microfinanças à regulação e supervisão realizadas por autoridades nacionais. Desse modo, cada país tende a adotar um modelo regulatório próprio, mais bem adaptado à realidade doméstica do setor e do sistema financeiro como um todo.

Nesse sentido, instituições operadoras de microcrédito tendem a substituir metodologias tradicionais de concessão de crédito por alternativas intensivas em trabalho e em informação, baseadas em avaliação de caráter, contratos de responsabilidade conjunta (aval social, banca comunitária ${ }^{3}$ ) e em estimativas de fluxos de caixa dos clientes (JANSSON e WENNER, 1998: p.9). Por sua vez, os portfólios de microcrédito tendem a apresentar grandes volumes de transações de curto prazo e com valores reduzidos, renovadas múltiplas vezes ao ano de modo condicional ao pagamento do empréstimo anterior e com valores crescentes, mecanismo denominado loan ladder (GREMAUD e TONETO JR., 2002: pp.99-100). Esses incentivos dinâmicos tendem a ser empregados por instituições que adotam metodologias de concessão individual de microcrédito, sendo cruciais para garantir baixas taxas de inadimplência (MENDOZA e VICK, 2010: pp. 548-549). As metodologias de crédito e o grande volume de transações de pequeno montante tornam os custos unitários operacionais de microcrédito significativamente mais elevados do que em operações de crédito tradicionais, com a necessidade de maiores taxas de juros para garantir a viabilidade dos negócios e da própria instituição de microfinanças (ROSENGARD, 2011: pp.163-165).

\footnotetext{
${ }^{3}$ A metodologia de aval social (ou grupo solidário) envolve a concessão de empréstimo para um grupo de três a sete indivíduos (GÓIS e SILVA, 2007: p.21) que dividem os recursos e a responsabilidade de pagamento. Seu intuito é dispensar a necessidade de colateral formal, minimizando riscos de seleção adversa e reduzindo custos de transação e de monitoramento. Baseia-se no conhecimento local dos indivíduos, que formam o grupo por conta própria (autosseleção) e tendem a não aceitar a participação de pessoas com risco de inadimplência, bem como em mecanismos de pressão social para garantir a adimplência (GREMAUD e TONETO JR., 2002: p.98). A metodologia de banca comunitária adota estruturas de incentivos semelhantes. Contudo, os grupos formados envolvem de dez a cinquenta pessoas, que decidem o valor que será repassado para cada membro e passam a poupar parte do recurso em uma conta interna. autoadministrada (GÓIS e SILVA, 2007: p.23). Em ambos os modelos, o papel de intermediação entre o grupo e a instituição é realizado pela figura do agente de crédito.
} 
Para além, problemas de governança podem surgir em decorrência das estruturas jurídicas e institucionais adotadas pelas instituições atuantes no setor. A estrutura de propriedade (conselho administrativo) de uma instituição de microfinanças pode ser composta por doadores, investidores privados, agências internacionais de desenvolvimento, representantes de funcionários e de clientes e ONGs que se mantém envolvidas na administração de instituições criadas a partir de processos de upgrading (BERENBACH e CHURCHILL, 1997: p.20).

Um desafio inicial se dá pelo fato de, em especial no caso de ONGs, os recursos direcionados para portfólios de microfinanças não serem investidos diretamente por seus administradores (Tchakoute-Tchuigoua, 2010: p.437). Desse modo, ao contrário do que ocorre com bancos comerciais, os incentivos poderiam não ser suficientemente fortes para que esses administradores buscassem garantir uma performance financeira responsável, dado que o desempenho da instituição não possui influência direta sobre seus investimentos pessoais (CHRISTEN e ROSENBERG, 2000: p.3) ${ }^{5}$. Relacionada a esse ponto está a questão de alguns administradores privilegiarem objetivos socais em detrimento da sustentabilidade financeira, podendo arriscar a própria sobrevivência da instituição e afetar negativamente seus clientes. Um terceiro fator de risco diz respeito a sistemas internos de supervisão e de prestação de contas falhos de muitas instituições de microfinanças, associados à possível falta de expertise necessária por parte de alguns dos atores envolvidos na supervisão interna da gerência da IMF (FERNANDO, 2004: p.13).

\footnotetext{
${ }^{4}$ Nesse ponto, é interessante observar a distinção feita por Tchakoute-Tchuigoua (2010) acerca dos conceitos de ownership e controle. É relevante a diferenciação entre o agente (gerente da instituição) e o principal (aquele cujos recursos são investidos na instituição, arcando com os riscos residuais e tendo direito a ganhos residuais). Potenciais diferenças de objetivos entre esses dois atores dão origem aos chamados problemas de agência (HARTARSKA, 2004: p.1628).

${ }^{5}$ Armendariz e Morduch apontam para o fato de, ao contrário de outros modelos jurídicos, organizações sem fins lucrativos não poderem distribuir lucros a acionistas, um fator que possivelmente afasta investidores sem objetivos sociais (ARMENDÁRIZ e MORDUCH, 2010: p.242) e que pode dificultar a sustentabilidade financeira dessas instituições. Entretanto, Mersland e Strom (2008, pp.608-610) não encontram diferenças significativas em termos de sustentabilidade financeira entre ONGs e companhias de capital aberto (SHF). Os autores concluem que ambos os formatos jurídicos encontraram modelos de negócios sustentáveis para operar em mercados de microfinanças. Desse modo, ONGs não seriam necessariamente mais orientadas para aspectos sociais do que SHF, nem estas seriam mais comercialmente orientadas do que as primeiras.
} 
Problemas de governança podem se desenvolver também a partir de processos de upgrading. Na ausência de uma separação adequada entre as administrações da ONG original e da nova instituição regulada, aumenta a possibilidade de ocorrerem problemas como falta de transparência, insider dealing e arbitragem regulatória. Nesses casos, usase a instituição regulada para adquirir financiamentos mais facilmente, enquanto a ONG original emprega esses recursos para a concessão de microcrédito de forma não regulada, evitando restrições como limites de juros, por exemplo. Trata-se, portanto, de um mecanismo para usufruir dos benefícios oferecidos por cada modelo (GALLARDO, 2001: p. 23). Um exemplo frequentemente citado na literatura é o da ONG colombiana Corposol que, na década de 1990, fundou a instituição regulada Finansol. A manutenção do controle administrativo efetivo da primeira sobre a segunda resultou em práticas direcionadas para evitar regulações e, desse modo, pouca transparência frente a seus clientes e às autoridades. Somadas a métodos gerenciais pouco recomendáveis, o resultado foi uma das maiores crises enfrentadas por uma instituição de microfinanças (CHRISTEN e ROSENBERG, 2000: p.4).

Instituições de microfinanças de maior porte tendem a apresentar um grande número de filiais, enquanto suas metodologias de concessão de crédito dependentes de laços comunitários, avaliações de caráter e estimativas de fluxo de caixa demandam a atuação de agentes de microcrédito nos locais de trabalho dos tomadores de empréstimos. Além de tudo, a dependência de um amplo volume de empréstimos de pequenos valores, com retornos reduzidos por operações, faz com que lucros possam se transformar rapidamente em prejuízos devido a aumentos da inadimplência. Embora resulte de adaptações necessárias a características de seus clientes, como ausência de colateral formal, moradia em localidades de acesso mais difícil e demanda por pequenos montantes de crédito, esse modelo descentralizado de operações dificulta ainda mais a tarefa de supervisão interna, que demanda assim informações precisas sobre o estado do portfólio de microcrédito da instituição e a atuação de agentes de crédito e filiais para o gerenciamento efetivo e para a rápida identificação de problemas mais graves (BERENBACH e CHURCHILL, 1997: pp. 21-22).

Para IMFs que oferecem serviços de depósitos e poupança, esses riscos são amplificados em decorrência do envolvimento de recursos do público mais amplo, muitas vezes indivíduos de baixa renda que podem perder a maior parte de suas economias em caso de falência da instituição. Em vista disso, parece haver um relativo 
consenso na literatura acerca da necessidade de regulação prudencial e de supervisão por parte de autoridades governamentais em situações em que depósitos do público são intermediados em novos empréstimos (GALLARDO, 2001: p.7). Em contrapartida, muitos autores entendem que as demais IMFs não devem ser sujeitas à supervisão direta devido ao grande número de instituições pequenas e informais atuantes no setor (BERENBACH e CHURCHILL, 1997: p.27), que associadas aos recursos limitados disponíveis resultariam em demandas irreais impostas às autoridades de supervisão (CULL et al, 2009: p.2).

Ademais, a literatura também apresenta argumentos contrários à regulação, como a possibilidade de captura regulatória por instituições já estabelecidas no setor com o intuito de evitar a entrada de novos competidores (STIGLER, 1971 apud HARTARSKA e NADOLNYAK, 2007: p.1210). Outros pontos levantados são a possibilidade de regulação excessiva, com restrições desnecessárias em termos de serviços oferecidos, número de filiais, região de atuação, entre outras, e a adoção de medidas desenvolvidas para um tipo específico de metodologia de crédito e aplicadas universalmente (CHRISTEN e ROSENBERG, 2000: p. 15).

Considerando essas particularidades, a regulação e a supervisão do setor de microfinanças assumem formas distintas, dependendo das opções de cada país quanto a sua operacionalização. Em termos de supervisão, autoridades nacionais como o Banco Central ou superintendência bancária podem atuar diretamente, como ocorre no setor financeiro tradicional. Pode ser adotada uma abordagem híbrida, com a delegação a terceiros, como auditorias ou, em alguns casos, bancos estatais consolidados no setor. Supervisão por outra agência governamental também é uma alternativa (ROSENGARD, 2011: pp.166-168). Quanto à regulação de IMFs, ela pode ser enquadrada no marco legal existente para instituições financeiras tradicionais, com algumas adequações. Por outro lado, é possível que ocorra a criação de um marco legal especial para o segmento de IMF e adaptado para as especificidades de portfólios de microcrédito (BERENBACH e CHURCHILL, 1997: pp. 24-25). Uma abordagem regulatória escalonada (tiered regulation), com limites entre as categorias em termos de fontes de funding, serviços oferecidos e grupo de clientes atendidos, entre outros critérios, é outra possibilidade (HARTARSKA e NADOLNYAK, 2007: pp.1209-1211). Finalmente, a autossupervisão e autorregulação através de associações de IMFs, a despeito de 
problemas de conflito de interesses (GALLARDO, 2001: p.30), e a ausência de qualquer tipo de regulação e supervisão são alternativas.

O desenvolvimento e atuação do setor de microfinanças são afetados de diferentes formas de acordo com o modelo e as medidas regulatórias e de supervisão vigentes. Políticas inadequadas podem apresentar efeitos negativos, elevando custos sem uma redução compatível de riscos enfrentados (JANSSON e WENNER, 1998: p. 5). Nesse sentido, a literatura apresenta uma série de tradeoffs entre regulação e supervisão e a organização e o desempenho do segmento de microfinanças.

\subsection{Regulação e Supervisão Financeira - Efeitos sobre as Microfinanças}

É possível identificar a existência de um padrão na literatura acerca dos efeitos da regulação e supervisão sobre as microfinanças. Em geral, além da estrutura do setor (número e tipo de instituições) existem três elementos das operações do segmento que tendem a ser afetados por medidas regulatórias. O primeiro deles, alcance, envolve a capacidade de uma IMF atrair clientes, e apresenta dois aspectos distintos. Sua profundidade (depth) visa o nível de vulnerabilidade dos clientes atendidos, geralmente em termos de renda e de gênero. Quanto mais clientes de renda reduzida e do sexo feminino atendidos, maior a profundidade do alcance de uma $\mathrm{IMF}^{6}$. Por sua vez, a amplitude (breadth) de uma instituição de microfinanças abrange o total de indivíduos e microempresas atendidos (OLIVARES-POLANCO, 2005: p.50).

O segundo elemento apontado pela literatura é a sustentabilidade financeira, ou a capacidade de IMFs manterem suas operações e promoverem crescimento institucional com os recursos à sua disposição. Diferentes autores empregam variáveis distintas em sua medição. Autossustentabilidade Operacional (OSS) inclui em seu cálculo as despesas financeiras (funding), provisões contra inadimplência e despesas operacionais, não levando em consideração eventuais subsídios existentes (HATARSKA e NADOLNYAK, 2007: p.1214). Autossustentabilidade financeira envolve cálculo semelhante, mas leva em conta a existência de subsídios na tentativa de determinar a

\footnotetext{
${ }^{6}$ A questão de gênero é relevante por se considerar que mulheres são consideradas como relativamente mais pobres, e por isso tendem a ser o foco de muitos programas de microfinanças (OLIVARESPOLANCO, 2005: p 58). De fato, a primeira Conferência Mundial sobre as Mulheres, organizada sob o viés institucional da Organização das Nações Unidas (ONU), identificou o acesso ao crédito como um obstáculo central para a saída da pobreza (OLSEN, 2010: p.503).
} 
capacidade de uma IMF cobrir seus gastos em sua ausência (GUTIÉRREZ-NIETO et al, 2011: p.402) ${ }^{7}$.

Finalmente, o terceiro elemento consiste na adimplência de portfólios de microcrédito. A variável normalmente usada na literatura é o portfólio sob risco (PAR), avaliando a porcentagem do portfólio de microcrédito com problemas de inadimplência em um período de tempo determinado. (LUTZENKIRCHEN, 2012: p.2).

Em relação aos tipos de regulação que possuiriam influência sobre esses aspectos das microfinanças, é possível categorizá-los em regulação e supervisão prudenciais e regulação e supervisão não prudenciais. Este último pode ainda ser dividido em cinco tipos distintos de controle, seguindo a classificação de Jansson e Werner (1998, pp.11-12) já discutida. Processos de transformação e downscaling, também sofrem a influência de medidas regulatórias e impactam o setor e as operações das microfinanças.

\subsubsection{Regulações Prudenciais}

Os custos administrativos dos portfólios de crédito de instituições de microfinanças tendem a ser consideravelmente maiores em comparação a portfólios de empréstimos tradicionais devido a seu grande volume de transações de valores reduzidos. Sendo assim, quaisquer fatores que resultem em maiores custos, como é o caso de regulação e supervisão prudenciais, podem gerar a necessidade de aumento nas taxas de juros praticadas sobre microcrédito ou estimular o movimento upmarket, de migração para clientes de maior renda, cuja tendência é demandar empréstimos de valores mais elevados (ARMENDARIZ e MORDUCH, 2010: p.250). Ambas as estratégias visam a manutenção da sustentabilidade financeira da instituição, e tendem a afetar de modo negativo o alcance a clientes de menor renda (BERENBACH e CHURCHILL, 1997: p.32).

\footnotetext{
${ }^{7}$ Retorno sobre ativos (ROA) e retorno sobre equity (ROE) são outras variáveis empregadas na medição da sustentabilidade financeira, geralmente não incluindo subsídios.

8 Autores como Hermes e Meesters (2011, p.182) e Hatarska e Nadolnyak (2007, p.1208) apresentam argumento semelhante. Cull et al (2009, pp.19-25) fazem uma diferenciação entre instituições que privilegiam o aspecto comercial das microfinanças e aquelas com maior foco em objetivos sociais. No primeiro caso, o autor encontra indícios de que os valores de empréstimos de instituições supervisionadas tendem a ser significativamente maiores do que para aquelas não supervisionadas. Dessa forma, a rentabilidade seria mantida em detrimento do alcance. No caso de IMFs não orientadas comercialmente,
} 
A adequação regulatória a normas prudenciais amplia os custos das instituições financeiras por demandar a contratação de trabalhadores especializados e por exigir um maior número de funcionários engajados na produção dos relatórios frequentes exigidos pelos supervisores, o que tende a reduzir o número de agentes de crédito atuando junto aos clientes e, em consequência, também o alcance da instituição (CULL et al, 2009: p.22). A produção de relatórios é complicada pelo grande volume de transações de pequenos valores presente nos portfólios de microcrédito. No mesmo sentido, os custos da regulação prudencial tendem a ser mais elevados para essas instituições devido a existência de economias de escala, ou seja, os custos médios de adequação tendem a ser menores para instituições de maior porte (CULL et al, 2009: pp.2-3).

Exigências excessivas de adequação de capital para portfólios de microfinanças podem resultar em menor alavancagem de seus recursos e, dessa forma, em uma quantidade subótima de intermediação de capital. O resultado seria a redução dos retornos obtidos, afetando negativamente também o interesse de investidores privados no setor (JANSSON e WENNER, 1998: p.24). Por esse ângulo, a sustentabilidade financeira de IMFs certamente seria prejudicada. Medidas regulatórias demandando taxas elevadas de provisão contra perdas no portfólio de crédito, tanto em termos de um valor geral previamente definido quanto em termos específicos por empréstimo, podem ter efeitos semelhantes sobre a sustentabilidade de IMFs. Para além, regras de adequação de capital e de provisão contra perdas penalizando empréstimos sem colateral podem dissuadir ONGs a passar pelo processo de transformação (CUEVAS, 1996: pp. 206-207). Tanto no caso de adequação de capital quanto no de provisão contra perdas, exigências muito elevadas em comparação com a base de capital da IMF podem colocar em risco a própria sobrevivência da instituição (JANSSON e WENNER, 1998: p.26).

Resultados encontrados por Hatarska e Nadolnyak (2007, p.1217) indicam a ausência de relação direta entre status regulatório e as dimensões de performance financeira e alcance de instituições de microfinanças. Dessa maneira, instituições reguladas não apresentariam, necessariamente, maior sustentabilidade financeira e alcance em comparação a instituições não reguladas. Por sua vez, Cull identifica que

instituições supervisionadas apresentam menor sustentabilidade financeira do que as instituições não supervisionadas. Por consequência, a rentabilidade é reduzida de modo a manter o foco em alcance dessas instituições. 
IMFs sujeitas a supervisão regular não apresentam taxas de lucro superiores àquelas de instituições não supervisionadas frequentemente. A capacidade de IMFs orientadas comercialmente e supervisionadas manterem sua rentabilidade compensaria, em parte, os resultados negativos de IMFs socialmente orientadas e supervisionadas em sua amostra (CULL et al, 2009, pp.17-19). Hatarska (2004, p.1639) encontra indícios de que a supervisão financeira não afeta nem a sustentabilidade nem o alcance de IMFs.

Entretanto, os resultados de Hatarska e Nadolnyak (2007, p.1220) também apontam para o fato de que maiores níveis de captação de depósitos estariam associados a um número mais elevado de tomadores ativos de microcrédito. Assim, a regulação apresentaria efeitos positivos indiretos sobre o alcance de IMFs ao possibilitar a oferta de serviços de depósito e poupança. Outro possível efeito positivo da regulação e supervisão sobre instituições de microfinanças seria a transmissão de maior segurança a investidores, incentivando seu envolvimento no segmento e aumentando a disponibilidade de recursos para IMFs financiarem suas atividades (ARMENDARIZ e MORDUCH, 2010: p.257). Dessa forma, o acesso a novas fontes de recursos pode, em parte, compensar os custos gerados pela regulação e pela supervisão, especialmente ao reduzir ou eliminar a dependência de subsídios (GREMAUD e TONETO JR., 2002: p.94). A ideia de que IMFs empregando fontes de recursos diversificadas apresentam maior sustentabilidade financeira parece corroborar essa ideia (Hatarska e Nadolnyak, 2007: p.1217).

Finalmente, Cull et al (2009, p.22) encontram evidências da influência negativa da supervisão financeira sobre a adimplência dos portfólios de microcrédito, efeito corroborado por Ahlin (2011, p.116) ao avaliar os efeitos de regulação sobre IMFs. Embora Cull et al hesitem em tirar conclusões nesse sentido, Ahlin et al apresentam duas explicações alternativas, ambas considerando a existência de regulações do setor como um indício de instituições domésticas de "melhor qualidade". Assim sendo, uma hipótese seria a existência também de regulações específicas sobre as atividades de microempresas e microempreendedores, clientes de IMFs. Os maiores custos impostos aos tomadores de microcrédito resultariam em dificuldades na manutenção da adimplência. A segunda hipótese aponta para a menor dependência de serviços de IMFs em um ambiente institucional mais robusto, reduzindo a disciplina de pagamento de seus clientes. Ela está de acordo com a ideia de que IMFs tendem a prosperar em 
ambientes de pouco desenvolvimento do sistema financeiro, competindo com instituições tradicionais pela atração de clientes (HERMES et al, 2009: p.7).

\subsubsection{Regulação não Prudencial}

Taxas de juros cobradas sobre microempréstimos apresentam relevância significativa para o modelo de negócios do setor. Elas são responsáveis por cobrir os custos com funding no caso de instituições que empregam fontes comerciais de financiamento e os custos administrativos de identificação e seleção de clientes, processamento de empréstimos e coleta de pagamentos, bem como garantir os recursos direcionados para adequação de capital e provisão contra inadimplência. As especificidades do modelo de negócios das IMFs fazem com que custos operacionais respondam por uma parcela considerável das despesas totais dessas instituições, implicando na necessidade de taxas de juros mais elevadas do que as praticadas em operações de crédito tradicionais (HELMS e REILLE, 2004: p.3). Embora as taxas sejam maiores, é possível que o custo absoluto do microcrédito seja razoável em relação tanto à capacidade de pagamento de seus clientes quanto aos valores reduzidos e ao curto prazo das operações (ARMENDÁRIZ e MORDUCH, 2010: p.254) ${ }^{9}$.

Limites de juros podem assumir três tipos distintos, de acordo com a forma como são estabelecidos. O primeiro deles é o de controles de juros, parte de leis bancárias que garantem a autoridade do banco central para determinar taxas máximas de juros de empréstimos concedidos por instituições financeiras reguladas. Por sua vez, leis de usura são parte do código civil e habilitam as autoridades bancárias a definirem limites às taxas de juros que podem ser praticadas por emprestadores privados (instituições reguladas nem sempre são sujeitas a essas leis). Ambos são exemplos de controles de proteção, conforme as categorias definidas por Jansson e Wenner (1998, p.9) para medidas regulatórias não prudenciais. Finalmente, os tetos de fato não são codificados legalmente, mas existem na prática a partir de taxas de juros cobradas por programas governamentais subsidiados. Dessa forma, instituições concorrentes são

\footnotetext{
${ }^{9}$ A despeito do argumento bastante presente na literatura de que indivíduos de menor renda se importam mais com o acesso a crédito do que com seu custo (juros cobrados), Armendariz e Morduch (2010, pp.252-253) também apontam para a sensibilidade da demanda por microcrédito a aumentos muito bruscos nas taxas de juros. Em contrapartida, aumentos em menor escala não parecem ter efeitos significativos sobre a demanda.
} 
obrigadas a praticar taxas equivalentes quando possível, de modo a não perder clientes (HELMS e REILLE, 2004: p.8). Nesse caso, trata-se de um exemplo de controle alocativo de taxas de juros.

Apesar das diferenças, esses três modelos apresentam potencial para impactar de modo significativo o ambiente de microfinanças de um país. É importante ressaltar, entretanto, que tal impacto depende tanto do enforcement dessas medidas quanto do nível em que está estabelecido o limite de juros e se ele possibilita ou não às IMFs cobrirem seus custos (HELMS e REILLE, 2004: pp.8-9). Sua definição a partir dos juros praticados pelo sistema bancário tradicional tende a resultar em níveis menores de taxas de juros e, portanto, potencialmente prejudiciais às microfinanças.

Caso realmente aplicados e a níveis relativamente baixos, conforme apontam Christen e Rosenberg (2000, p.7), limites de juros podem tornar a operação de microcrédito em um país insustentável ao impedir que as instituições cubram seus custos. Outro efeito apontado pelos autores, encontrado também no caso de regulação prudencial, é a redução do atendimento a clientes mais pobres e/ou localizados em mercados de mais difícil acesso (zonas rurais, por exemplo). Enquanto essa migração para clientes de maior renda reduz a profundidade do alcance, ela minimiza os problemas de sustentabilidade financeira ocasionados, compensando através da redução dos gastos operacionais. Um terceiro efeito, apontado por Helms e Reille (2004, pp.5-7) seria a retirada de IMFs do mercado ou mesmo incentivos reduzidos para que bancos comerciais se envolvessem no setor de microfinanças (downscaling). Em contrapartida, autores como Vanroose (2010, p.50) não encontram efeitos significativos dos limites de juros sobre a sustentabilidade ou sobre o alcance das $\operatorname{IMFs}^{10}$.

Outro tipo de regulação não prudencial abordado na literatura é o de barreiras referentes a controle e ownership de instituições de microfinanças, que podem impedir tanto a entrada de novas instituições no setor quanto o engajamento de novos atores dotados do objetivo e da capacidade de promoção das microfinanças. Um exemplo de controle macroeconômico, a proibição de indivíduos e entidades estrangeiras se tornarem acionistas em instituições bancárias, em alguns casos estendida também à sua direção e gerência, impedem o envolvimento de organizações internacionais

\footnotetext{
10 A autora reconhece, no entanto, que os resultados encontrados talvez indiquem a ausência de enforcement ou a existência de tetos de juros suficientemente elevados para não prejudicar as operações de IMFs em sua amostra.
} 
especializadas em microfinanças no país. A impossibilidade de IMFs domésticas atraírem recursos de ONGs e investidores estrangeiros, bem como de se beneficiar da experiência dessas organizações, poderia resultar em limitações ao crescimento financeiramente sustentável e à expansão do alcance do setor doméstico de microfinanças, bem como ao processo de transformação de IMFs sem fins lucrativos (GALLARDO, 2001: p.25).

No mesmo sentido, leis que demandam estruturas organizacionais específicas para a aquisição de licenças de operação financeira, como corporações com acionistas ou sociedades anônimas no caso de instituições bancárias (GALLARDO, 2001: p.30), podem dissuadir ONGs de microfinanças a se tornarem entidades reguladas através do processo de transformação. Regulações limitando ownership e controle somente a pessoas físicas impedem que bancos criem unidades separadas para atividades de microcrédito (CHRISTEN e ROSENBERG, 2000: p.17), prática bastante empregada em processos de downscaling. Ao delimitarem exigências para a participação no mercado de crédito, ambas constituem exemplos de controles não prudenciais organizacionais.

Pelo fato de definirem padrões técnicos mínimos para a operação no setor de microfinanças, medidas como restrições a empréstimos sem colateral formal, exigências de documentação específica para a concessão de crédito e limites ao crescimento do portfólio devido a alta proporção de custos operacionais, também podem ser classificadas como controles organizacionais. Normalmente existentes em contextos domésticos em que o segmento de microfinanças foi inserido no marco regulatório do sistema financeiro tradicional, esses tipos de regulação podem aumentar os custos das operações de IMFs (ROSENGARD, 2011: p.164), afetando negativamente tanto a profundidade quanto a amplitude de seu alcance (BERENBACH e CHURCHILL, 1997: p.60). Limites legais para que IMFs restrinjam o local de estabelecimento de suas filiais, os serviços por elas oferecidos e prejudiquem a definição dos horários de funcionamento de acordo com as demandas de seus clientes podem apresentar efeitos semelhantes (JANSSON e WENNER, 1998: pp.41-42), embora constituam controles estruturais.

Historicamente, o desenvolvimento das microfinanças teria sido favorecido pela liberdade ou mesmo ausência de regulação sobre o setor, possibilitando a implementação de inovações em termos de metodologias de concessão de crédito e 
serviços com relativa facilidade (HATARSKA e NADOLNYAK, 2007: p.1208). Nessa lógica, regulações demasiado restritivas em relação a exigências de colateral formal, documentação específica e atuação de filiais, mas também em outros tipos de regulação aqui abordados (tanto prudenciais quanto não prudenciais), podem limitar inovações financeiras no segmento. Dada sua centralidade para que IMFs sejam capazes de reduzir custos e manter o alcance a grupos de menor renda, os efeitos podem ser negativos em ambos os aspectos (ROSENGARD, 2011: p.169).

Outro exemplo de controle estrutural são as exigências de capital de entrada para novas instituições no segmento de microfinanças. Elas apresentam efeitos distintos de acordo com o nível em que são estabelecidas, sendo que tanto pisos baixos quanto os mais elevados influenciam na estrutura do setor de microfinanças (JANSSON e WENNER, 1998: pp.13-15). Exigências relativamente baixas de capital favorecem a formação de um setor doméstico com grande quantidade de pequenas instituições reguladas, característica que pode gerar demandas exageradas sobre autoridades de supervisão, em muitos casos em contextos de escassez de recursos.

A competição intensa por clientes resultante do elevado número de instituições pode incentivar movimentações upmarket, sacrificando a profundidade do alcance em benefício da sustentabilidade financeira da instituição. Exigências de capital baixas podem ainda atrair instituições mais propensas a comportamentos de risco, uma ameaça aos recursos de clientes e ao setor de microfinanças como um todo (BERENBACH e CHURCHILL, 1997: p.60).

No caso de exigências de capital mais elevadas, o resultado pode ser um setor de microfinanças composto por um número reduzido de instituições reguladas de grande porte. Barreiras de entrada para potenciais competidores dificultam o processo de transformação de ONGs de microfinanças em instituições reguladas por causa das dificuldades de arrecadação dos recursos exigidos e de se atingir uma base de clientes com escala suficiente para a alavancagem do capital. Gallardo (2001, p.26) defende a necessidade de maiores níveis de capital para IMFs devido às maiores dificuldades dessas instituições em reunir e injetar recursos adicionais em casos de problemas. Entretanto, níveis mais elevados podem acabar por dissuadir o envolvimento de investidores, reduzindo possibilidades de alavancagem de equity e diminuindo o alcance das IMFs (CUEVAS, 1996: p. 202). 
Regulação acerca de como deve ocorrer a capitalização de novas instituições também interfere na estrutura do setor de microfinanças. Exigências de que ela seja feita estritamente através de aportes de recursos têm como objetivo garantir o início das operações da nova IMF sem incertezas acerca do valor de seus ativos. Contudo, ao eliminar a possibilidade de que a capitalização ocorra por meio da transferência direta do portfólio de microcrédito de uma ONG, tais exigências acabam por impedir o processo de transformação. Restaria a possibilidade de transferência de recursos e clientes conforme empréstimos pendentes fossem pagos, embora a existência de regras demandando aporte completo do capital exigido antes do início das atividades da nova IMF elimine também essa opção (JANSSON e WENNER, 1998: p.17).

\subsubsection{Upgrading, Downscaling e Competição}

Conforme afirmado acima, a literatura indica que exigências de capital demasiado elevadas, restrições sobre o formato da capitalização de novas instituições e exigências de modelos organizacionais específicos para a obtenção de licenças financeiras podem dissuadir processos de upgrading. Em contrapartida, estruturas regulatórias escalonadas (tiered regulation) tendem a fomentar a busca de ONGs e IMFs semiformais pelo processo de transformação. Isso ocorreria devido à existência de trajetórias previamente definidas para a composição de instituições formais e para o maior acesso a fontes comerciais de financiamento atreladas a esse novo status (GALLARDO, 2001: p.23).

Tendo em vista que instituições que realizam a captação de depósitos apresentam maior alcance em termos de amplitude, processos de upgrading de ONGs de microfinanças podem afetar positivamente essa dimensão das operações. Isso ocorreria porque, em muitos países, o status de instituição regulada garante a possibilidade de acesso a depósitos do público, fonte de funding mais confiável e barata (OLSEN, 2010: p.508; ARUN, 2005: p.352). Contudo, um fator de controvérsia acerca da ampliação do atendimento a clientes diz respeito à questão de desvio da missão social de fornecimento de serviços financeiros a indivíduos vulneráveis (mission drift), objetivo geralmente apresentado por ONGs antes do processo de transformação. Também devido aos maiores custos de instituições reguladas, o processo de upgrading pode resultar na instituição transformada, ampliando seu alcance através do atendimento a clientes de renda mais elevada e de maiores valores de empréstimos (FERNANDO, 
2004: pp-22-27). Contudo, o número absoluto de clientes de menor renda pode ser mantido ou mesmo ampliado por meio de subsídios cruzados e ganhos em termos de economias de escala (CULL et al, 2011: p.151).

Além de tudo, as oportunidades de acesso a linhas comerciais de financiamento, ao mercado interbancário e a garantias de depósito tendem a aumentar (BERENBACH e CHURCHILL, 1997: p.31) com o emprego dessa gama mais ampla, podendo contribuir para maior sustentabilidade financeira. A possibilidade de oferecimento de outros tipos de microsserviços para além de crédito e poupança seria outro fator capaz de atrair novos clientes (FERNANDO, 2004: p.14).

Por sua vez, conforme abordado anteriormente, movimentos de downscaling de bancos comerciais podem ser dificultados por restrições de controle e ownership por parte de pessoas jurídicas, dado que afetam diretamente os modelos de negócios adotados para sua entrada no segmento de microfinanças. No mesmo sentido, limites de juros que prejudiquem a recuperação dos custos podem levar à desistência de bancos comerciais se aventurarem no setor. Isso ocorre porque o processo de downscaling de bancos e outras instituições financeiras para o setor de microfinanças é, em muitos casos, incentivado pela lucratividade dos microempréstimos de IMFs operando no segmento.

A consequência da entrada de instituições bancárias é o aumento da competição no setor, mecanismo mais eficaz na redução das taxas de juros praticadas por operadores de microfinanças ao gerar a necessidade de ganhos de eficiência nos serviços oferecidos (HELMS e REILLE, 2004: p.11) ${ }^{11}$. Para não perderem clientes para seus novos competidores, IMFs são forçadas a reduzir custos e melhorar a qualidade dos serviços oferecidos, inclusive através de sua diversificação com microsseguros, micropoupanças, entre outros (HERMES et al, 2011: p.930). Assim, downscaling pode estimular IMFs a incorporarem técnicas e tecnologias empregadas por bancos comerciais, com possíveis ganhos de eficiência decorrentes (HERMES et al, 2009: p.6).

Portanto, a competição em igualdade de condições pode resultar em maiores inovação e eficiência nos serviços de microfinanças, com a redução dos custos das IMFs e dos preços praticados atraindo novos clientes para o setor. Porém, competição distorcida pode ser prejudicial para o setor de microfinanças. Mediante a existência de

\footnotetext{
${ }^{11}$ Em contrapartida, Mersland e Strom (2009, pp.666-668) encontram indícios de que a competição não possui efeitos sobre a performance de IMFs e, portanto, não traz benefícios para seus clientes.
} 
instituições ineficientes mantidas através de subsídios, outras IMFs, incapazes de competir em condições de igualdade, podem optar pela busca por clientes de renda mais elevada, em detrimento da profundidade do alcance (OLSEN, 2010: p.506).

O processo de downscaling pode atrair clientes de IMFs para instituições bancárias, muitas vezes capazes de oferecer menores taxas de juros, maior variedade de empréstimos e valores mais elevados. A consequente redução dos clientes de IMFs teria efeitos negativos também sobre a autossuficiência financeira dessas instituições (HERMES et al, 2009: pp-6-7). Uma consequência alternativa é a erosão da eficácia dos incentivos dinâmicos existentes nas metodologias de crédito empregadas por IMFs, apontadas como essenciais para garantir a adimplência dos clientes do setor (CULL et all, 2011: pp.153-155). Empréstimos sequenciais e condicionais e loan ladders tendem a não funcionar diante da possibilidade de obtenção de crédito em outras instituições.

No mesmo sentido, mercados saturados pelo excesso de oferta de serviços de microfinanças, com um grande número de instituições atuando no setor, podem reduzir o número de clientes por instituição (OLSEN, 2010: pp.507). O acirramento da competição e a escassez de novos clientes de baixo risco podem ter uma série de consequências negativas. Instituições podem relaxar critérios de avaliação e monitoramento para a concessão de microcrédito, incorporando tomadores com maiores possibilidades de inadimplência (LUZENKIRCHEN, 2012: pp.10-12) ${ }^{12}$. Dessa forma, facilitam ou mesmo estimulam o endividamento exagerado dos clientes do segmento. É o caso de instituições que iniciam suas atividades de microfinanças e passam a identificar e atrair clientes mais promissores de instituições já existentes. Os resultados, especialmente na ausência de compartilhamento de informações de crédito de clientes do setor, são a contratação de múltiplos empréstimos e o endividamento exagerado (MENDOZA e VICK, 2010: pp.558-559). Assim, tomadores podem optar por defaults estratégicos em empréstimos de uma ou mais instituições, correndo poucos riscos ao

\footnotetext{
${ }^{12} \mathrm{O}$ problema de comportamento mais arriscado de muitas IMFs diante da maior competição teria sido agravado, no período anterior à crise financeira de 2008, pela abundância de funding disponível para o setor de microfinanças nos mercados internacionais. Seguindo um padrão boom-bust observado muitas vezes em mercados financeiros tradicionais, os cortes nos fluxos de investimentos após a eclosão da crise teriam resultado em cortes drásticos na concessão de novos empréstimos. Somente então teriam sido identificadas as significativas vulnerabilidades dos portfólios de muitas IMFs, com a magnitude do ritmo de sua deterioração e de sua amplitude geográfica sendo inéditos para o segmento até então (WAGNER, 2012: pp.199-204).
} 
fazê-lo. Trata-se do problema de moral hazard abordado anteriormente, tanto em relação ao comportamento das instituições quanto ao dos clientes. Logo, a maior competição no setor pode resultar em maior inadimplência, com efeitos negativos sobre a sustentabilidade financeira de IMFs (HERMES et al, 2009: p.7).

Abaixo (Figura 3 e Figura 4) encontram-se sumarizadas as principais hipóteses encontradas na literatura acerca dos efeitos da regulação sobre o setor de microcrédito, discutidas neste capítulo:

\begin{tabular}{|c|c|c|c|}
\hline Tipo Regulatório & $\begin{array}{c}\text { Categoria } \\
\text { Regulatória }\end{array}$ & Efeitos & Possíveis Mecanismos \\
\hline $\begin{array}{c}\text { Exigências de } \\
\text { Relatórios e } \\
\text { Adequação a } \\
\text { Normas } \\
\text { Prudenciais }\end{array}$ & Prudencial & Alcance & $\begin{array}{l}\text { 1) Maiores taxas de juros; 2) } \\
\text { Migração para clientes de } \\
\text { maior renda; 3) Menos agentes } \\
\text { de crédito disponíveis }\end{array}$ \\
\hline $\begin{array}{l}\text { Adequação de } \\
\text { Capital e taxas de } \\
\text { provisão contra } \\
\text { inadimplência }\end{array}$ & Prudencial & $\begin{array}{c}\text { Sustentabilidade } \\
\text { Financeira/ Estrutura do } \\
\text { Setor }\end{array}$ & $\begin{array}{l}\text { 1) Menos recursos disponíveis } \\
\text { para alavancagem; 2) Menor } \\
\text { atração de investidores; 3) } \\
\text { Menos lucros; 4) Dissuasão do } \\
\text { processo de transformação; 5) } \\
\text { Risco de falência }\end{array}$ \\
\hline $\begin{array}{c}\text { Status de } \\
\text { Regulação e } \\
\text { Supervisão }\end{array}$ & Prudencial & $\begin{array}{c}\text { Sustentabilidade } \\
\text { Financeira/ Alcance/ } \\
\text { Adimplência }\end{array}$ & $\begin{array}{c}\text { 1) Ausência de relação } \\
\text { direta/ sem efeitos sobre } \\
\text { essas dimensões; 2) Efeitos } \\
\text { positivos indiretos ao } \\
\text { permitir serviços de } \\
\text { depósitos de poupança; 3) } \\
\text { Efeitos positivos sobre } \\
\text { sustentabilidade financeira: } \\
\text { acesso a novas fontes de } \\
\text { funding, maior confiança } \\
\text { de investidores e menor } \\
\text { dependência de subsídios; } \\
\text { 4) Emprego de fontes } \\
\text { diversificadas de funding } \\
\text { resulta em maior } \\
\text { sustentabilidade financeira; } \\
\text { 5) Supervisão resulta em }\end{array}$ \\
\hline
\end{tabular}




\begin{tabular}{|c|c|c|c|}
\hline & & & $\begin{array}{c}\text { maior inadimplência. } \\
\text { Regulações também sobre } \\
\text { empresas e clientes, } \\
\text { maiores custos e } \\
\text { dificuldades de pagamento. } \\
\text { Menor dependência dos } \\
\text { recursos de microcrédito } \\
\text { pelos clientes, menores } \\
\text { incentivos para } \\
\text { adimplência }\end{array}$ \\
\hline $\begin{array}{l}\text { Barreiras de } \\
\text { Controle e } \\
\text { Ownership }\end{array}$ & $\begin{array}{l}\text { Controle não } \\
\text { prudencial } \\
\text { macroeconômico/ } \\
\text { controle não } \\
\text { prudencial } \\
\text { organizacional }\end{array}$ & $\begin{array}{c}\text { Alcance/Sustentabilidade } \\
\text { Financeira/Estrutura do } \\
\text { Setor }\end{array}$ & $\begin{array}{c}\text { 1) Proibição de ownership e } \\
\text { controle por estrangeiros: } \\
\text { dificuldade de atração de } \\
\text { recursos e experiência de } \\
\text { ONGs e investidores; 2) } \\
\text { Exigências de estruturas } \\
\text { organizacionais específicas } \\
\text { para a aquisição de licenças de } \\
\text { operação financeira, dissuasão } \\
\text { da transformação; 3) Restrições } \\
\text { a pessoas jurídicas prejudica } \\
\text { downscaling }\end{array}$ \\
\hline $\begin{array}{c}\text { Exigências de } \\
\text { Colateral Formal, } \\
\text { Documentação } \\
\text { Específica e } \\
\text { Limites ao } \\
\text { Crescimento do } \\
\text { Portfólio } \\
\text { (decorrentes de } \\
\text { custos } \\
\text { operacionais } \\
\text { elevados) }\end{array}$ & $\begin{array}{l}\text { Controle não } \\
\text { prudencial } \\
\text { organizacional }\end{array}$ & $\begin{array}{c}\text { Alcance (profundidade e } \\
\text { amplitude) }\end{array}$ & $\begin{array}{l}\text { 1) Aumento dos custos; 2) } \\
\text { Limitação a inovações; 3) } \\
\text { Limitações de alcance a um } \\
\text { maior número de clientes e a } \\
\text { clientes de baixa renda }\end{array}$ \\
\hline $\begin{array}{c}\text { Limites Legais } \\
\text { para Filiais (local, } \\
\text { serviços e } \\
\text { horários) }\end{array}$ & $\begin{array}{c}\text { Controle não } \\
\text { prudencial } \\
\text { estrutural }\end{array}$ & Alcance & $\begin{array}{c}\text { 1) Custos operacionais } \\
\text { elevados; 2) Limitação a } \\
\text { inovações; 3) Limitações de } \\
\text { alcance a número mais elevado } \\
\text { de clientes e a clientes de baixa } \\
\text { renda }\end{array}$ \\
\hline
\end{tabular}




\begin{tabular}{|c|c|c|c|}
\hline $\begin{array}{c}\text { Exigências de } \\
\text { Capital de Entrada }\end{array}$ & $\begin{array}{l}\text { Controle não } \\
\text { prudencial } \\
\text { estrutural }\end{array}$ & $\begin{array}{c}\text { Estrutura do Setor/ } \\
\text { Alcance (profundidade) }\end{array}$ & $\begin{array}{l}\text { 1) Pisos Baixos: a) Setor com } \\
\text { grande quantidade de } \\
\text { instituições reguladas de } \\
\text { pequeno porte; b) Competição } \\
\text { elevada; c) Migração para } \\
\text { clientes de maior renda, d) } \\
\text { Atração de instituições mais } \\
\text { propensas a riscos, possíveis } \\
\text { problemas para o setor; 2) Pisos } \\
\text { Elevados: a) Setor composto } \\
\text { por número reduzido de } \\
\text { instituições reguladas de grande } \\
\text { porte; b) Dissuasão da } \\
\text { transformação de ONGs, } \\
\text { dificuldades em arrecadação } \\
\text { dos recursos exigidos, em se } \\
\text { atingir escala de clientes para } \\
\text { alavancagem suficiente de } \\
\text { capital; c) Menor atração de } \\
\text { investidores; d) Redução da } \\
\text { alavancagem; e) Redução do } \\
\text { alcance }\end{array}$ \\
\hline $\begin{array}{l}\text { Capitalização de } \\
\text { Novas Instituições }\end{array}$ & $\begin{array}{l}\text { Controle não } \\
\text { prudencial } \\
\text { organizacional }\end{array}$ & Estrutura do Setor & $\begin{array}{l}\text { 1) Impossibilidade de } \\
\text { transferência direta de portfólio; } \\
\text { 2) Limitações ao processo de } \\
\text { transformação de ONGs; 3) } \\
\text { Regras exigindo aporte } \\
\text { completo impedem a } \\
\text { transferência paulatina de } \\
\text { recursos }\end{array}$ \\
\hline Limites de Juros & $\begin{array}{c}\text { Controle não } \\
\text { prudencial de } \\
\text { proteção/ controle } \\
\text { não prudencial } \\
\text { alocativo }\end{array}$ & $\begin{array}{c}\text { Sustentabilidade } \\
\text { Financeira/ Alcance/ } \\
\text { Estrutura do Setor }\end{array}$ & $\begin{array}{l}\text { 1) Impedem IMFs de cobrir } \\
\text { custos, prejudicando ou mesmo } \\
\quad \text { impossibilitando a } \\
\text { sustentabilidade financeira; 2) } \\
\text { Migração para clientes de maior } \\
\text { renda e mais fácil acesso, } \\
\text { reduzindo custos; 3) Retirada de } \\
\text { IMFs do mercado, dissuasão de } \\
\text { downscaling de bancos; 4) }\end{array}$ \\
\hline
\end{tabular}




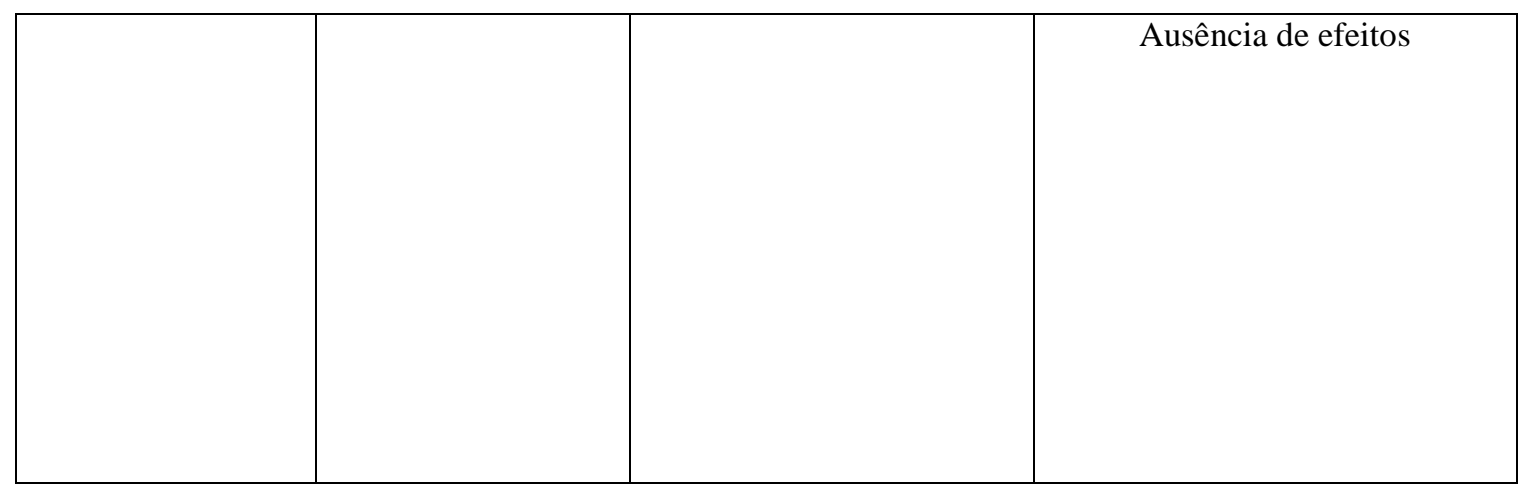

Figura 3. Tipos Regulatórios, seus Efeitos e Mecanismos de Ação sobre o Setor de Microfinanças

Fonte: Elaboração própria, a partir da bibliografia discutida no capítulo.

\begin{tabular}{|c|c|c|}
\hline $\begin{array}{c}\text { Upgrading, } \\
\text { Downscaling e } \\
\text { Competição }\end{array}$ & Efeitos & Possíveis Mecanismos \\
\hline $\begin{array}{l}\text { Estruturas } \\
\text { Regulatórias } \\
\text { Escalonadas }\end{array}$ & Estrutura do Setor & $\begin{array}{l}\text { 1) Trajetórias previamente definidas para a composição de } \\
\text { instituições formais e acesso a fontes comerciais de } \\
\text { financiamento; 2) Fomento ao processo de transformação }\end{array}$ \\
\hline Transformação & $\begin{array}{l}\text { Alcance (amplitude e } \\
\text { profundidade)/ } \\
\text { Sustentabilidade } \\
\text { Financeira }\end{array}$ & $\begin{array}{c}\text { 1) Obtenção do status de instituição regulada; 2) } \\
\text { Possibilidade de acesso a depósitos do público; 3) } \\
\text { Ampliação da amplitude do alcance; 4) Maiores custos de } \\
\text { instituições reguladas; 5) Foco em clientes de renda mais } \\
\text { elevada, maiores valores de empréstimo; 6) Número } \\
\text { absoluto de clientes de baixa renda ampliado (subsídios } \\
\text { cruzados e economias de escala); 7) Acesso ampliado a } \\
\text { linhas comerciais, mercado interbancário e garantias de } \\
\text { depósito; 8) Oferecimento de outros tipos de } \\
\text { microsserviços, maior atração de clientes; 9) Maior } \\
\text { sustentabilidade financeira }\end{array}$ \\
\hline Downscaling & $\begin{array}{c}\text { Competição/ } \\
\text { Alcance/ } \\
\text { Sustentabilidade } \\
\text { Financeira/ } \\
\text { Adimplência }\end{array}$ & $\begin{array}{l}\text { 1) Aumento da competição 2)Redução de taxas de juros; 3) } \\
\text { Melhoria e diversificação dos serviços oferecidos; 4) } \\
\text { Estímulo à incorporação por parte de IMFs de técnicas e } \\
\text { tecnologias empregadas por bancos comerciais; 5) Ganhos } \\
\text { de eficiência; 6) Atração de novos clientes; 7) Instituições } \\
\text { ineficientes mantidas por subsídios em condição de } \\
\text { vantagem; 8) Busca por clientes de renda mais elevada } \\
\text { pelas outras IMFs, menor profundidade do alcance; 9) } \\
\text { Perda de clientes pelas IMFs, sustentabilidade financeira } \\
\text { prejudicada; 10) Perda da eficácia de incentivos dinâmicos }\end{array}$ \\
\hline
\end{tabular}




\begin{tabular}{|l|l|c|}
\hline & $\begin{array}{c}\text { das metodologias de microcrédito; 11) Menor número de } \\
\text { clientes por instituição, incorporação de clientes de maior } \\
\text { risco; 12) Aumento da inadimplência }\end{array}$ \\
\hline
\end{tabular}

Figura 4. Movimentos de Upgrading e Downscaling, seus Efeitos e Mecanismos de Ação sobre o Setor de Microfinanças

Fonte: Elaboração própria, a partir da bibliografia discutida no capítulo.

\section{Estudo de Caso - Brasil}

Atualmente, o segmento de microfinanças brasileiro é composto por um conjunto de instituições da sociedade civil, do setor público e da iniciativa privada. Dentre seus participantes estão ONGs, Organizações da Sociedade Civil de Interesse Público (OSCIPs), Sociedades de Crédito ao Microempreendedor e à Empresa de Pequeno Porte (SCMEPP), financeiras (muitas vezes coligadas a bancos privados), cooperativas de crédito, Bancos do Povo operando a partir de fundos públicos estaduais e municipais, Agências de Fomento, Caixa Econômica Federal e bancos comerciais e múltiplos, públicos e privados com carteira especializada em microcrédito (GARCIA, 2010: p.79).

A autorização para captação de depósitos do público por parte de instituições que operam microcrédito é limitada a cooperativas de crédito, a bancos comerciais e a bancos múltiplos com carteira comercial, além da Caixa Econômica Federal. Contudo, ONGs, OSCIPs e SCMEPPs constituem parte relevante do setor, ficando restritas a fontes de financiamento como doações e empréstimos de organizações nacionais e internacionais de desenvolvimento, emprego de recursos próprios ou repasses governamentais.

Esses modelos institucionais, atuantes no oferecimento de serviços de microcrédito diretamente ao cliente final, são classificados como de "primeiro piso". Eles recebem apoio de instituições como o BNDES, SEBRAE, BIRD, BID, OIT e Acción International, entre outras, cuja atuação envolve atividades de capacitação, assistência técnica e provisão de recursos financeiros às IMFs, sendo classificadas como de "segundo piso" (RIBEIRO e CARVALHO, 2006: p.148).

No Brasil, partindo de uma visão mais ampla, é possível identificar a existência de três tipos distintos de operações creditícias consideradas serviços de microcrédito. $\mathrm{O}$ primeiro tipo abarca as operações de crédito de valores reduzidos, a princípio direcionadas à população de baixa renda, cujos recursos são usados com frequência para 
fins de consumo e pagamentos de dívidas, ainda que sejam usualmente identificadas como microcrédito. Trata-se do crédito direto ao consumidor (CDC).

Um segundo tipo é o de microcrédito produtivo, de pequeno valor e voltado para atividades produtivas, sem metodologia específica de concessão de crédito. Finalmente, o terceiro diz respeito ao microcrédito produtivo orientado, voltado para atividades produtivas e baseado na atuação personalizada da instituição de microcrédito junto ao empreendedor, materializada na figura dos agentes de crédito. Essa terceira denominação foi adotada pelo governo federal na lei que constituiu o PNMPO (MONZONI, 2006: pp.24-26).

Enquanto a diferenciação entre o primeiro tipo e os demais reside na possibilidade de emprego dos recursos para consumo e pagamento de dívidas, o microcrédito produtivo e o microcrédito produtivo orientado se distinguem pela metodologia de concessão de crédito, baseada na atuação do agente de crédito no segundo caso (GÓIS e SILVA, 2007: p.14). De um modo ou de outro, os três tipos estão inseridos no desenvolvimento histórico do setor de microcrédito brasileiro.

\subsection{Histórico}

No Brasil, o movimento de microfinanças teria apresentado quatro "ondas institucionais" entre seu início na década de 1970 e o ano de 2002 (NICHTER et al, 2002: pp.22-24). Em um primeiro momento, o setor teria se desenvolvido a partir de instituições afiliadas a redes internacionais. O Projeto UNO (União Nordestina de Assistência a Pequenas Organizações), uma das primeiras iniciativas a nível mundial, iniciou suas operações no ano de 1973, na região Nordeste do país, recebendo apoio da ONG Aitec, atualmente denominada ACCION International (MIGUEL, 2011: p.10). O Projeto UNO deixou de operar no fim da década de 1980, mas surgiram outras organizações voltadas para atuação com microcrédito. Dentre elas, a rede CEAPE (Centros de Apoio aos Pequenos Empreendimentos), ainda atuante em diversos estados brasileiros, bem como o Banco da Mulher e a Visão Mundial, apoiados por, respectivamente, ACCION International e Banco Interamericano de Desenvolvimento (BID), Women's World Banking e World Vision.

A segunda fase, a partir da década de 1990, teria sido composta por instituições locais desenvolvendo metodologias particulares para atender comunidades de baixa renda. Casos como o da ONG Portosol contaram com apoio dos governos municipal e 
estadual no Rio Grande do Sul. Em contrapartida, instituições como a Vivacred conseguiram atrair recursos do setor privado para estabelecer suas operações (RIBEIRO e CARVALHO, 2006: pp.145-146).

A terceira "onda institucional" teria sido constituída a partir de iniciativas governamentais. A criação de diversos Bancos do Povo a nível municipal e estadual e o estabelecimento do Programa Crediamigo pelo Banco do Nordeste do Brasil (BNB) têm suas origens nessa fase. No âmbito federal, a constituição da Comunidade Solidária, em 1995, deu início à construção de uma nova agenda de desenvolvimento social para o país. As Rodadas de Interlocução Política do Conselho da Comunidade Solidária, em especial aquelas voltadas para "Alternativas de Ocupação e renda" (1997), "Marco Legal do Terceiro Setor" (1997-1998) e "Expansão do Microcrédito no Brasil" (2001) contribuíram para a constituição direta e indireta de políticas públicas de concessão de crédito como forma de combate à pobreza, pautando-se pela construção de pontes com a sociedade civil e da promoção de um papel mais ativo desta e do setor privado no desenvolvimento social (BARONE e ZOUAIN, 2007: pp.373-75).

A Rodada referente a "Alternativas de Ocupação e Renda" apontou o microcrédito como uma importante estratégia para a temática, resultando na criação de um grupo de trabalho com participantes apontados pelo Banco Central do Brasil, Ministério da Fazenda, BNDES e outros órgãos cujo objetivo seria a elaboração de propostas para seu incentivo e regulamentação. A partir da atuação desse grupo, o Conselho Monetário Nacional (CMN) lançou a Resolução n 2.627, de agosto de 1999, consolidando a Medida Provisória $n^{\circ}$ 1894-19, de 10 de junho do mesmo ano. Marco pioneiro da atuação da iniciativa privada no setor de microcrédito, a resolução regulamentou a constituição e funcionamento das Sociedades de Crédito ao Microempreendedor (SCMs), instituições com fins lucrativos e com o único objetivo social de conceder financiamentos a microempresas e a pessoas físicas, com o objetivo exclusivo de viabilizar empreendimentos de pequeno porte (BARONE e ZOUAIN, 2007: p.375-77).

Por sua vez, a Rodada referente ao "Marco Legal do Terceiro Setor" identificou a necessidade de regulamentar o conjunto de organizações da sociedade civil, facilitando sua atuação em parceria com o Estado. Entre outras medidas, a Lei ${ }^{\circ}$ 9.790, de 23 de março de 1999, ou Lei do Terceiro Setor, criou a figura das Organizações da Sociedade Civil de Interesse Público (OSCIPs), um avanço significativo para o marco 
legal da sociedade civil e para o desenvolvimento do microcrédito (BARONE e ZOUAIN, 2007: pp.375-376).

Finalmente, a Rodada de "Expansão do Microcrédito no Brasil" (2001) teve como resultado a edição da Resolução $n^{\circ} 2.874$, de 26 de julho de 2001, alterando o marco legal das SCMs, já consolidado pela Lei $\mathrm{n}^{\circ}$ 10.194, de fevereiro do mesmo ano, na busca por maior flexibilização e por tornar mais atrativas para investidores suas regras operacionais para investidores (BARONE e ZOUAIN, 2007: p.378).

Destarte, a partir da segunda metade da década de 1990, a atuação estatal desempenhou papel significativo na evolução do microcrédito no Brasil, delineando as bases para um marco legal próprio ao setor, cujo desenvolvimento ocorrera até então sem qualquer tipo de regulamentação específica. No mesmo sentido, o governo passou a fomentar a formação de uma rede de instituições operadoras de microcrédito, abrangendo tanto a iniciativa privada quanto a sociedade civil (CONSTANZI, 2002: p.24).

Nesse contexto, destaca-se a atuação do Banco Nacional de Desenvolvimento Econômico e Social (BNDES), que passou a disponibilizar linhas de crédito e a oferecer capacitação e apoio ao desenvolvimento institucional a organizações operadoras de microcrédito. Entre as iniciativas com a participação do Banco estavam o Programa de Crédito Produtivo Popular (PCPP), criado em 1996 mediante autorização do Ministério do Trabalho e Emprego (MTE) e do Conselho Deliberativo do Fundo de Amparo ao Trabalhador (CODEFAT) e o Programa de Desenvolvimento Institucional (PDI), desenvolvido em anos posteriores a partir de parcerias com o Banco Interamericano de Desenvolvimento e o MTE (PEREIRA, 2007: p.9).

Finalmente, a quarta fase identificada por Nichter et al (2002, pp.22-23) teria se desdobrado a partir do início da década de 2000, marcada pela maior participação de instituições financeiras públicas e privadas a partir de uma orientação baseada em estratégias mais comerciais, em muitos casos partindo de um ambiente regulado. Nesse sentido, parece haver relação direta com a visão da administração de Fernando Henrique Cardoso acerca da necessidade de estimular a atuação de entidades privadas como forma de desenvolver o setor brasileiro de microcrédito.

A perspectiva predominante até então no governo era a de microfinanças como microcrédito produtivo, cujo objetivo seria o de geração de trabalho e de aumento da renda de pessoas físicas e de pequenos empreendedores. Em um momento inicial, sob a 
administração de Lula da Silva, as microfinanças foram inseridas em um conjunto de medidas visando a inclusão social da população mais pobre via mercado, ampliando o acesso a serviços bancários, particularmente ao crédito em pequena escala, ainda que para consumo (MIGUEL, 2011: p.15).

Nessa nova conjuntura, o microcrédito passou a ser encarado como crédito de pequeno valor, com ou sem fins produtivos, capaz de gerar renda. Insere-se nesse contexto o chamado "pacote de microcrédito", lançado em 25 de junho de 2003, quando foram adotadas uma série de medidas voltadas para a bancarização, direcionamento de recursos para operações de microcrédito e para o desenvolvimento do cooperativismo de crédito. A Resolução no 3.104 do Conselho Monetário Nacional (CMN), substituída no mês seguinte pela Resolução $\mathrm{n}^{\circ} 3.113$, criou o modelo de contas especiais de depósito à vista. Por sua vez, a Resolução $n^{\circ} 3.106$ regulamentou a existência de cooperativas de crédito de livre associação. Finalmente, a Medida Provisória $\mathrm{n}^{\mathbf{0}} 122$, posteriormente convertida na Lei $\mathrm{n}^{\mathrm{o}} 10.735$, estabeleceu o direcionamento de parcela dos depósitos à vista captados por instituições bancárias para operações de crédito de pequenos valores.

Outra medida no mesmo sentido, autorizada em setembro de 2003 pela Lei $\mathrm{n}^{\circ}$ 10.738, foi a constituição do Banco Popular do Brasil, banco múltiplo subsidiário ao Banco do Brasil voltado para o desempenho de atividades de microfinanças e que teve suas operações encerradas em maio de 2008. Assim, o foco não era necessariamente o desenvolvimento das micro e pequenas empresas. A nova lógica de crédito popular visava incentivar o consumo, o que geraria demanda para o crescimento do emprego e da renda na economia (BARONE e SADER, 2008: pp.1251-1255).

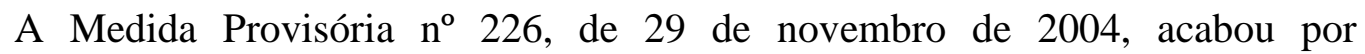
complementar essa visão inicial sobre as microfinanças ao constituir o Programa Nacional de Microcrédito Produtivo Orientado (PNMPO). Partindo da perspectiva da geração de trabalho e renda como forma de redução das desigualdades no país, o Programa, consolidado pela Lei $\mathrm{n}^{\circ} 11.110$, de 25 de abril de 2005, buscou ampliar o acesso ao microcrédito no Brasil e promover atividades produtivas de pequeno porte desempenhadas por pessoas físicas e jurídicas (MIGUEL, 2011: pp.12-13).

Trata-se de um modelo de política pública cuja estrutura em rede é composta por instituições operadoras de microcrédito, que optam por participar do Programa de forma autônoma e condicionada à habilitação concedida pelo Ministério do Trabalho e 
Emprego (MTE). Entre os modelos institucionais legalmente autorizados a operar no âmbito do PNMPO estão desde instituições cujas operações financeiras são restritas à concessão de microcrédito, como OSCIPs e SCMs, até aquelas de atuação mais ampla, como cooperativas de crédito e instituições bancárias tradicionais (BARONE e SADER, 2008: p.1262).

O PNMPO visa a disponibilização de recursos voltados para o microcrédito produtivo orientado, empregando inicialmente fundos provenientes do Fundo de Amparo ao Trabalhador (FAT), conforme estipulado pelas Resoluções $n^{\circ} 449$ e $n^{\circ} 511$, emitidas pelo CODEFAT, respectivamente, em de 29 de agosto de 2005 e 18 de outubro de 2006, e do direcionamento compulsório de depósitos à vista efetuados no sistema bancário. Além de que, busca garantir a articulação entre instituições voltadas para a concessão de microcrédito produtivo orientado e instituições operadoras de recursos públicos, de modo a assegurar a continuidade dos fluxos de repasse de recursos (PEREIRA, 2007: p.5).

A partir da segunda metade da década, o governo brasileiro passou a adotar medidas de fomento à formalização de micronegócios. O Estatuto Nacional da Microempresa e da Empresa de Pequeno Porte, estabelecido pela Lei Complementar $\mathrm{n}^{\mathrm{o}}$ 123, de 14 de dezembro de 2006, foi uma das tentativas iniciais nesse sentido. Em julho de 2009, passou a vigorar a Lei Complementar $n^{\circ} 128$, alterando disposições do Estatuto no sentido de reduzir custos e burocracia no processo de formalização da economia. Era criada a figura jurídica do Microempreendedor Individual (MEI), cujos direitos e vantagens envolvem inscrição no CNPJ, possibilidade de emissão de nota físcal, benefícios de previdência social e acesso a treinamentos oferecidos pelo SEBRAE (SANTOS, 2014: 128).

Em busca de ampliar recursos direcionados para a inclusão produtiva da população de menor renda, o Governo Federal lançou, em 25 de agosto de 2011, o Crescer - Programa Nacional de Microcrédito, inserido no âmbito do PNMPO. Seus operadores são o Banco do Brasil, a Caixa Econômica Federal, o Banco da Amazônia e o Banco do Nordeste, este através do Programa Crediamigo. Com foco em microempreendedores formais ou informais com renda bruta anual de até $\mathrm{R} \$ 120$ mil, o Crescer prevê operações de crédito no montante máximo de $\mathrm{R} \$ 15$ mil por cliente e prazo médio de seis meses para capital de giro e de dois anos para investimentos (SANTOS, 2014: p.134-135). 
Na mesma data, o Conselho Monetário Nacional emitiu a Resolução nº 4.000, nova medida com o intuito de fortalecer o microcrédito produtivo orientado para a população de menor renda. Dos $2 \%$ de saldo de depósitos à vista previstos para aplicação em microcrédito, $80 \%$ passaram a ser obrigatoriamente direcionados para microcrédito produtivo orientado, enquanto os $20 \%$ restantes poderiam ser direcionados para o crédito popular de consumo ${ }^{13}$.

Durante o IV Fórum do Banco Central sobre Inclusão Financeira, em 2012, o presidente do Banco Central, Alexandre Tombini, anunciou o aprimoramento do marco regulatório do setor por meio de dois atos normativos do CMN. A Resolução $n^{\circ} 4152$, de 30 de outubro, buscou uma maior padronização com a definição de microcrédito, por ela considerado "operação de crédito realizada com empreendedor urbano ou rural, pessoa natural ou jurídica, independentemente da fonte dos recursos ${ }^{14}$ ". Para se caracterizar uma operação de microcrédito, é obrigatório também o emprego de metodologia específica, envolvendo avaliação de riscos, análise de receitas e despesas e mecanismos de controle e acompanhamento.

Por sua vez, a Resolução no 4.153 versou sobre a exigibilidade de aplicação de parcela de depósitos à vista, alterando a Resolução $\mathrm{n}^{\circ} 4.000$ no sentido de gerar maior eficiência e criar condições mais favoráveis à ampliação do total de aplicações (FELTRIM, 2014: p.141).

Finalmente, em 26 de setembro de 2017, o governo brasileiro promulgou a Medida Provisória $n^{\circ}$ 802, visando simplificar a legislação referente ao PNMPO. Foram ampliados os limites de renda ou receita bruta para participação nas operações do Programa por pessoas físicas e jurídicas dedicadas a atividades produtivas. Com o intuito de minimizar custos, foi removida a obrigação de acompanhamento presencial em todas as etapas do processo, passando a existir a possibilidade de contato à distância a partir da primeira visita ${ }^{15}$.

\footnotetext{
${ }^{13}$ BRASIL. Banco Central do Brasil. Resolução nº 4.000, de 25 de agosto de 2011. D.O.U., 26/08/2011.

${ }^{14}$ BRASIL. Banco Central do Brasil. Resolução no . 4.152, de 30 de outubro de 2012. D.O.U., 31/10/2012.

${ }^{15}$ BRASIL. Medida Provisória no. 802, de 27 de setembro de 2017. D.O.U., 28/09/2017.
} 


\subsection{Regulamentação das Microfinanças no Brasil}

Entre o fim da década de 1990 e o ano de 2017, a legislação brasileira relacionada ao setor de microcrédito passou por alterações substanciais, evidenciando os esforços governamentais voltados para o desenvolvimento do setor.

\subsubsection{ONGs e Organizações da Sociedade Civil de Interesse Público}

Organizações não governamentais foram instituições pioneiras no setor de microfinanças brasileiro, se desenvolvendo em meio à ausência de regulamentação por parte do Estado. Na década de 1990, os debates no âmbito da Comunidade Solidária e as tentativas de fortalecimento do setor nacional de microcrédito acabaram por alterar esse cenário.

A Lei $\mathrm{n}^{\circ}$ 9.790, de março de 1999, ou Lei do Terceiro Setor, criou a possibilidade de ONGs adotarem a qualificação de Organizações da Sociedade Civil de Interesse Público (OSCIPs). Tanto ONGs quanto OSCIPs são pessoas jurídicas de direito privado e sem fins lucrativos, que não fazem parte do Sistema Financeiro Nacional, sendo-lhes vedadas a captação de depósitos do público e a distribuição de excedentes operacionais.

A obtenção de qualificação como OSCIP, condicionada à aprovação do Ministério da Justiça, exige que a instituição possua um dos objetivos sociais previstos em lei, como a experimentação não lucrativa de sistemas alternativos de produção, comércio, emprego e crédito ${ }^{16}$. Em contrapartida, OSCIPs apresentam uma vantagem considerável em relação a organizações não governamentais no que diz respeito à operação no setor de microcrédito. A Medida Provisória no 1914-4, de julho de 1999, tornou as OSCIPs dedicadas a sistemas alternativos de crédito isentas dos limites de juros estabelecidos pelo código civil, o que foi ratificado, em agosto de 2001, pela Medida Provisória n ${ }^{\circ}$ 2172-32.

Constituídas a partir de aportes dos sócios fundadores, a Lei $\mathrm{n}^{\circ} 9.790$ possibilitou às OSCIPs captar recursos de doações, de entidades públicas ou privadas, da contratação de empréstimos de instituições financeiras nacionais e internacionais ou via Termo de Parceria com o poder público. Esse último consiste em uma espécie de

${ }^{16}$ BRASIL. Lei no . 9.790, de 23 de março de 1999. D.O.U., 24/03/1999. 
vínculo de cooperação, tendo como intuito o desempenho de atividades de interesse público relacionados ao objeto social da instituição.

No âmbito dos esforços do governo Lula da Silva para fortalecer o setor de microcrédito no país, a Resolução no 3.109 do Conselho Monetário Nacional, de julho de 2003, permitiu a aquisição de operações de OSCIPs por instituições sujeitas à exigibilidade de aplicação em microcrédito de parcela dos depósitos à vista ${ }^{17}$. Todavia, tais operações deveriam atender certos critérios, como cobrança de juros máximos de até $2 \%$ ao mês e limite máximo de mil reais por operação com microempreendedor. Apesar da aquisição, as OSCIPs continuariam responsáveis pela prestação dos serviços relacionados a essas operações.

\subsubsection{Sociedades de Crédito ao Microempreendedor e à Empresa de Pequeno Porte (SCMEPPs)}

As Sociedades de Crédito ao Microempreendedor (SCMs) foram outro modelo institucional criado no final da década de 1990 com base nos debates no âmbito da Comunidade Solidária, tendo em vista fomentar o desenvolvimento do setor nacional de microcrédito a partir da atuação de atores privados. Sua autorização, inicialmente prevista pela Medida Provisória $n^{\circ} 1.894$, de junho de 1999, ocorreu de forma definitiva com a conversão desta na Lei $n^{\circ} 10.194$, de fevereiro de 2001.

Definiu-se como objeto social exclusivo das SCMs a concessão de financiamentos a pessoas físicas e microempresas, com o intuito de viabilizar empreendimentos profissionais, comerciais ou industriais de pequeno porte. Equiparadas a instituições financeiras para efeitos de legislação, e sujeitas à fiscalização do Banco Central do Brasil (BCB), não lhes foi permitido captar recursos junto ao público ou emitir títulos e valores mobiliários destinados a oferta pública. A exemplo das OSCIPs, as Sociedades de Crédito ao Microempreendedor foram isentas pela Medida Provisória no 1914-4, de julho de 1999, dos limites de juros estabelecidos pelo código civil, regulamentação mantida pela Medida Provisória $n^{\circ}$ 2.172-32, de agosto de 2001.

A Resolução $n^{0}$ 2.627, de agosto de 1999, foi responsável por regulamentar a figura das SCMs, exigindo autorização do BCB para sua constituição e funcionamento. Instituições privadas com fins lucrativos, as Sociedades de Crédito ao

${ }^{17}$ BRASIL. Resolução n ${ }^{\text {3 } 3.109, ~ d e ~} 24$ de julho de 2003. D.O.U. 25/07/2003. 
Microempreendedor deveriam ser constituídas como companhias fechadas ou sociedades de quotas de responsabilidade limitada, sendo vedada a participação societária direta ou indireta do setor público em seu capital. Previu ainda possibilidade de organizações com atuação exclusiva no segmento de microcrédito se converterem em SCMs, estabelecendo um caminho para que OSCIPs envolvidas no setor se transformassem em instituições reguladas.

No mesmo sentido, a Resolução $\mathrm{n}^{\circ} 2.627$ definiu como limites líquidos de capital realizado e patrimônio líquido ajustado o valor de cem mil reais. Por sua vez, o limite de diversificação de risco poderia atingir um máximo de $\mathrm{R} \$ 10.000,00$ por cliente, vedados empréstimos para fins de consumo. Dada a proibição de SCMs captarem depósitos do público, suas fontes de financiamento ficaram limitadas a organismos e instituições de desenvolvimento, nacionais e internacionais, orçamentos estaduais e municipais, fundos constitucionais e doações. A instalação de pontos de atendimento ficou restrita à área geográfica da SCM, limitando sua atuação, não sendo permitidas sua transformação em outros tipos de instituições integrantes do SFN e sua participação no capital de empresas.

A Resolução $n^{\circ}$ 2.874, de julho de 2001, ampliou a atuação das Sociedades de Crédito ao Microempreendedor ao permitir a concessão de garantias a pessoas físicas e a pessoas jurídicas classificadas como microempresas, sempre com o intuito de viabilizar empreendimentos de pequeno porte. Além do mais, possibilitou que suas atividades fossem realizadas também por contrato de prestação de serviços em nome de instituição autorizada a desempenhá-las. Alterou-se a previsão de transformação de outros modelos institucionais em SCMs, permitindo-se em contrapartida que o controle societário destas fosse exercido por OSCIPs.

Em termos de limites, a Resolução $n^{\circ} 2.874$ estabeleceu cinco vezes o patrimônio líquido das SCMs como endividamento máximo, somados o passivo circulante, as coobrigações por cessão de créditos ou prestação de garantias, e descontadas as aplicações em títulos públicos federais. Em relação a fontes de financiamento, passou a ser permitida a aplicação de recursos no mercado financeiro. Por fim, foram criados os Postos de Atendimento de Microcrédito, a serem instalados em quaisquer localidades em que instituições financeiras desempenhem tais atividades creditícias. 
Em julho de 2003, a Resolução no 3.109, regulamentando a Medida Provisória ${ }^{\circ}$ 122, delimitou a exigibilidade de direcionamento de $2 \%$ dos saldos de depósitos à vista captados por uma dada instituição financeira para operações de microcrédito. Para cumprimento das exigências, consideraram-se tanto repasses de recursos para Sociedades de Crédito ao Microempreendedor, dentre outros modelos institucionais, quanto valores referentes a operações de adiantamentos, empréstimos e financiamentos adquiridos de SCMs e outras instituições que desenvolvessem atividades creditícias destinadas a microempreendedores.

Em setembro de 2007, tendo em vista debates realizados entre autoridades governamentais e participantes do setor acerca de como melhorar o modelo institucional (COSTA, 2010: p.24), a Lei $\mathrm{n}^{\circ} 11.524$ transformou as SCMs em Sociedades de Crédito ao Microempreendedor e a Empresa de Pequeno Porte (SCMEPP), que passaram a ter como objeto social a concessão de financiamentos e garantias não somente a pessoas físicas e microempresas, mas também às empresas de pequeno porte.

A regulamentação dada pela Resolução $n^{0}$ 3.567, de maio de 2008, alterou os limites existentes para as atividades das agora SCMEPPs. Exigências de capital realizado e patrimônio líquido mínimo passaram a ser de duzentos mil reais, enquanto o endividamento passou a ser de dez vezes o respectivo patrimônio líquido da instituição. Finalmente, a exposição de risco por cliente ficou limitada a 5\% do patrimônio líquido ajustado.

A Figura 5 indica que, entre 1999 e 2008, as alterações na regulamentação ocorreram no sentido de maior flexibilização do modelo das SCMEPPs, ainda que de forma gradual. Suas exigências de patrimônio líquido e capital realizado foram elevadas ao dobro, tendo o mesmo acontecido com o teto de endividamento. Sua diversificação máxima de risco por cliente passou a ser ajustável pelo patrimônio líquido da instituição, favorecendo o crescimento dessas instituições. Por fim, as SCMEPPs passaram a ter acesso a um número muito maior de clientes com a possibilidade de atender empresas de pequeno porte a partir de 2008.

\begin{tabular}{|c|c|c|c|}
\hline & Resolução $^{\mathbf{0}} \mathbf{2 . 6 2 7}$ & Resolução $^{\mathbf{0}} \mathbf{2 . 8 7 4}$ & ${\text { Resolução } \mathbf{n}^{\mathbf{0}} \mathbf{3 . 5 6 7}}^{\text {Publicação }}$ \\
\hline $\begin{array}{c}\text { Patrimônio } \\
\text { Líquido } \\
\text { Ajustado de 1999 }\end{array}$ & R\$ $100.000,00$ & Julho de 2001 & Maio de 2008 \\
\hline
\end{tabular}




\begin{tabular}{|c|c|c|c|}
\hline $\begin{array}{c}\text { Capital } \\
\text { Realizado }\end{array}$ & $\mathrm{R} \$ 100.000,00$ & $\mathrm{R} \$ 100.000,00$ & $\mathrm{R} \$ 200.000,00$ \\
\hline $\begin{array}{c}\text { Diversificação } \\
\text { de Risco (por } \\
\text { cliente) }\end{array}$ & $\mathrm{R} \$ 10.000,00$ & $\mathrm{R} \$ 10.000,00$ & $5 \%$ patrimônio líquido \\
\hline $\begin{array}{c}\text { Endividamento } \\
\text { Máximo }\end{array}$ & - & 5 x patrimônio líquido & $10 x$ patrimônio líquido \\
\hline Público-Alvo & $\begin{array}{c}\text { Pessoas físicas e } \\
\text { microempresas }\end{array}$ & $\begin{array}{c}\text { Pessoas físicas e } \\
\text { microempresas }\end{array}$ & $\begin{array}{c}\text { Empresas de pequeno } \\
\text { porte (Lei no } 11.524)\end{array}$ \\
\hline Área de Atuação & Limitada & Sem limitações & Sem limitações \\
\hline
\end{tabular}

Figura 5. Evolução Temporal do Quadro Regulatório das Sociedades de Crédito ao Microempreendedor e Empresa de Pequeno Porte (SCMEPPs)

Fonte: Elaboração própria a partir da legislação discutida.

\subsubsection{Cooperativas de Crédito}

As cooperativas de crédito, sociedades de natureza civil e sem fins lucrativos (RIBEIRO e CARVALHO, 2006: p.154), existentes no Brasil desde o início do século XX, foram classificadas pela primeira vez como instituições financeiras em 1964. Entretanto, apesar de medidas como a Lei no 5.764 , de 1971, responsável por constituir um marco legal para o sistema cooperativo, atividades de regulamentação mantiveramse relativamente estagnadas até o início da década de 1990. Mudanças passaram a ocorrer com esforços do Banco Central do Brasil para consultar os atores envolvidos em busca de melhorias para o setor de cooperativas de crédito (SOARES e SOBRINHO, 2008: pp. 71-73), tendo as principais mudanças referentes à sua regulamentação a partir da década de 2000 ocorrido na flexibilização dos critérios de associação e de exigências de capital realizado e de patrimônio líquido.

A Resolução $\mathrm{n}^{\circ}$ 2.608, de maio de 1999, buscou conceder flexibilidade à atuação das cooperativas de crédito ao reduzir limites de endividamento e de concentração de risco por cliente, passando para cinco vezes o patrimônio líquido ajustado (PLA) no caso de operações passivas e 5\% do PLA para operações ativas. Buscava-se também gerar incentivos para a organização do setor em sistemas integrados e supervisionados por cooperativas centrais de crédito, que seriam responsáveis pela capacitação técnica e auditoria das cooperativas singulares de crédito a elas filiadas. Assim, o capital realizado e o patrimônio líquido ajustado para cooperativas singulares de crédito foram definidos em cinquenta mil reais nos primeiros dois anos de existência da instituição, 
passando posteriormente a cem mil reais. Entretanto, cooperativas singulares filiadas a centrais teriam redução de $30 \%$ nesses limites, bem como prazo de três anos para ampliação automática das exigências. No caso das cooperativas centrais de crédito, os valores definidos foram oito vezes maiores.

A Resolução n 2.771, de setembro de 2000, fortaleceu ainda mais o papel das cooperativas centrais de crédito, a quem foi permitido prestar serviços de supervisão auxiliar, auditoria e treinamentos. Limites previstos de endividamento foram substituídos por exigências de patrimônio líquido compatível com grau de risco de estrutura de ativos, passivos e contas de compensação das cooperativas. Dessa forma, ficou definido em dez vezes o valor do PLA para a realização de operações passivas no caso de cooperativas singulares filiadas a centrais e de cinco vezes para cooperativas não filiadas.

No mesmo sentido, foram instituídos níveis para os limites de diversificação de risco por clientes, com restrições reduzidas para cooperativas de crédito filiadas a centrais e para a concessão de crédito realizada por essas centrais para suas instituições membro. Assim, estabeleceu-se em 25\% do PLA o limite de diversificação de risco para todas as cooperativas de crédito envolvidas em aplicações em títulos e valores mobiliários. Operações de crédito e de concessão de garantias poderiam ser de um máximo de $20 \%$ do PLA por cooperativas centrais de crédito com uma única filiada, de $10 \%$ por cooperativas singulares filiadas a centrais e de $5 \%$ para as não filiadas.

Finalmente, foi também reduzido o capital exigido para constituição de cooperativas de crédito, bem como prevista a adoção de cronograma para obtenção do patrimônio mínimo de funcionamento dessas instituições. Para cooperativas centrais, o capital mínimo integralizado na data de autorização de funcionamento deveria ser de sessenta mil reais, passando para PLA de cento e cinquenta mil após três anos e trezentos mil após cinco anos. Para cooperativas singulares filiadas a centrais, seu capital integralizado deveria ser, nos mesmos prazos, de três mil, trinta mil e sessenta mil reais. Em contrapartida, para singulares não filiadas a centrais, o valor mínimo do capital integralizado passou a ser de quatro mil e trezentos reais na data de autorização de funcionamento, quarenta e três mil reais após dois anos e oitenta e seis mil após quatro anos.

Conforme indicado na Figura 6, houve um refinamento das disposições entre a Resolução de maio de 1999 e a de setembro de 2000, com exigências mais palpáveis 
para instituições recém-constituídas e aumento progressivo ao longo dos anos, de forma a garantir sua solidez.

\begin{tabular}{|c|c|c|}
\hline & Resolução n 2.608 & Resolução no 2.771 \\
\hline Publicação & Maio 1999 & Setembro 2000 \\
\hline Singulares Filiadas & $\begin{array}{c}\mathrm{R} \$ 35.000 / \mathrm{R} \$ 70.000 \text { (após dois } \\
\text { anos) }\end{array}$ & $\begin{array}{l}\mathrm{R} \$ 3.000 \text { (início)/ R } \$ 30.000,00 \\
\text { (3 anos)/ R } \$ 60.000 \text { (5 anos) }\end{array}$ \\
\hline Singulares Não Filiadas & $\begin{array}{c}\mathrm{R} \$ 50.000 / \mathrm{R} \$ 100.000 \text { (após } \\
\text { dois anos) }\end{array}$ & $\begin{array}{c}\mathrm{R} \$ 4.300 \text { (início)/ } \mathrm{R} \$ 43.000 \text { (2 } \\
\text { anos)/ } \mathrm{R} \$ 86.000 \text { (4 anos) }\end{array}$ \\
\hline Centrais & $\mathrm{R} \$ 800.000,00$ & $\begin{array}{l}\mathrm{R} \$ 60.000 \text { (início)/ } \mathrm{R} \$ 150.000 \\
(3 \text { anos)/ } \mathrm{R} \$ 300.000 \text { (5 anos) }\end{array}$ \\
\hline
\end{tabular}

Figura 6. Evolução Temporal das exigências de Capital de Entrada e Patrimônio Líquido para Cooperativas de Crédito

Fonte: Elaboração própria a partir da legislação discutida.

Em dezembro de 2002, teve início o processo gradual de abertura em termos das possibilidades de associação às cooperativas de crédito. A Resolução $\mathrm{n}^{\circ} 3.058$ permitiu a formação de cooperativas de pequenos empresários, microempresários e de microempreendedores, desde que estes desempenhassem atividades industriais, comerciais ou de prestação de serviços, inclusive na área rural, com renda bruta igual ou inferior ao limite vigente na legislação para se categorizar como pequena empresa. Obrigatoriamente, essas cooperativas deveriam ser filiadas a cooperativas centrais de crédito (SOARES e SOBRINHO, 2008: pp. 77-79). Deste modo, estabeleceu-se como limite mínimo de capital de patrimônio de referência (PR) para esse novo modelo quarenta mil reais na data de autorização de funcionamento, oitenta mil reais após dois anos e cento e sessenta mil reais após quatro anos.

A Resolução n 3.106, de junho de 2003, deu continuidade ao processo de flexibilização das restrições de associação ao possibilitar a constituição de cooperativas de livre admissão de associados. No entanto, as cooperativas de maior complexidade operacional deveriam mandatoriamente se filiar a cooperativas centrais de crédito, por sua vez responsáveis por adotar precauções contra violações a normas legais por parte de suas filiadas. Logo, cooperativas de crédito de livre admissão teriam sua atuação limitada a áreas geográficas com até 100 mil habitantes nos casos de novas autorizações. Em compensação, para a transformação de cooperativas de crédito em 
funcionamento há mais de três anos, facultou-se a atuação em áreas com até 750 mil habitantes.

Limites mínimos de capital integralizado e de patrimônio de referência foram estabelecidos em dez mil reais iniciais, passando para sessenta mil reais após dois anos e cento e vinte mil após quatro anos para as cooperativas de livre associação atuantes em áreas com até 100 mil habitantes. Cooperativas de livre admissão atuando em área superior a cem mil habitantes teriam como exigência de PR seis milhões ou três milhões, dependendo de se tratar de região metropolitana ou não. Limites mínimos mantiveram-se inalterados para os demais modelos cooperativos, embora tenha passado a vigorar redutor de $50 \%$ para aquelas atuantes nas regiões Norte e Nordeste.

Por sua vez, a Resolução $n^{\circ} 3.140$, de novembro de 2003, possibilitou a criação de cooperativas de crédito de associação vinculada a entidade de classe específica, como de empresários vinculados a um mesmo sindicato ou associação patronal em funcionamento a período mínimo de três anos. Exigências impostas foram as mesmas já em vigor para as cooperativas de microempresários.

Em outubro de 2005, a Resolução $\mathrm{n}^{\circ} 3.321$ foi emitida na tentativa de estimular a formação de cooperativas de maior porte e viabilidade econômica, que poderiam atuar como indutoras da autossustentabilidade de cooperativas de porte menor (SOARES e SOBRINHO, 2008: pp.85-88). Assim sendo, ampliou de 100 para até 300 mil habitantes o teto populacional de área de atuação para que uma cooperativa de crédito estivesse submetida às exigências mais brandas de capital integralizado e patrimônio de referência.

No que diz respeito aos limites de exposição por clientes, cooperativas singulares passaram de $10 \%$ para $15 \%$ do Patrimônio de Referência quando filiadas a cooperativas centrais de crédito e de $5 \%$ para $10 \%$ quando não filiadas. Por sua vez, as centrais passaram a apresentar limites de $25 \%$ em relação a operações de mercado e $20 \%$ para operações de crédito e concessão de garantias, podendo também se valer dos limites.

Quanto ao capital integralizado e ao patrimônio de referência, as cooperativas singulares de microempresários tiveram seus limites alterados para dez mil reais na data de sua autorização, e cento e vinte mil reais após período de dois anos de funcionamento. Destarte, como observado na Figura 7, exigências iniciais foram 
reduzidas, embora tenha sido mantida a preocupação com a solidez das cooperativas no médio prazo.

\begin{tabular}{|c|c|c|}
\hline & Resolução no 3.058 & Resolução n $^{\mathbf{0} 3.321}$ \\
\hline Publicação & Dezembro 2002 & Outubro 2005 \\
\hline Cooperativas de Pequenos & & \\
Empresários, & $\mathrm{R} \$ 40.000$ (início)/ $\mathrm{R} \$ 80.000(2$ & $\mathrm{R} \$ 10.000$ (início)/ $\mathrm{R} \$ 120.000(2$ \\
Microempresários e & anos) / $\$ 160.000(4$ anos) & anos) \\
Microempreendedores & & \\
\hline
\end{tabular}

Figura 7. Evolução das exigências de Capital Realizado e de Patrimônio Líquido para Cooperativas de Pequenos Empresários, Microempresários e Microempreendedores

Fonte: Elaboração própria a partir da legislação discutida.

Cooperativas singulares de livre admissão localizadas nas regiões Norte, Nordeste e Centro-Oeste ou situada nas regiões Sul e Sudeste e com atuação em área com menos de cem mil habitantes tiveram limites similares estabelecidos, embora com prazo de quatro anos para se atingir PR de cento e vinte mil reais. Para as instituições atuantes nas regiões Sul e Sudeste do país, porém em áreas com população entre cem e trezentos mil habitantes, o capital integralizado foi definido como cinquenta mil reais na data de autorização de funcionamento e quinhentos mil reais de PR após quatro anos. Por fim, para cooperativas singulares de livre admissão de associados atuando em área superior a trezentos mil habitantes, PR de seis milhões ou de três milhões de reais, de acordo com sua localização. A essa última disposição, aplicou-se redução de $50 \%$ para as regiões Norte, Nordeste e Centro-Oeste.

A Resolução $\mathrm{n}^{\mathrm{o}}$ 3.442, de fevereiro de 2007, voltou a ampliar o limite populacional máximo para área de atuação de cooperativas de livre admissão, a partir de então equivalente a dois milhões de habitantes para instituições em funcionamento há mais de três anos. Assim, em termos de capital integralizado e de patrimônio de referência, para cooperativas de crédito de livre admissão de associados atuantes em área com menos de trezentos mil habitantes, o valor inicial foi alterado para vinte mil reais, passando para duzentos e cinquenta mil reais após quatro anos de funcionamento. Além disso, passou-se a exigir PR de três milhões de reais para as cooperativas de livre admissão atuantes em áreas entre trezentos mil e setecentos e cinquenta mil habitantes, e de seis milhões de reais para aquelas em área entre setecentos e cinquenta mil e dois 
milhões de habitantes. Foi mantido o redutor de 50\% nesses valores para as instituições cujas operações estivessem estabelecidas nas regiões Norte, Nordeste e Centro-Oeste do país.

Em maio de 2010, a Resolução $n^{\circ} 3.859$ promoveu a alteração mais recente na atuação de cooperativas de crédito de livre admissão, com estas podendo desempenhar suas atividades em áreas com população superior a dois milhões de habitantes desde que filiadas a cooperativa central de crédito inserida em sistema cooperativo de três níveis e que a confederação do respectivo sistema estivesse de acordo. O limite mínimo de capital integralizado para atuar em área com população superior a dois milhões de habitantes ficou estabelecido em vinte e cinco milhões de reais, valor reduzido pela metade quando nas regiões Norte, Nordeste e Centro-Oeste. A Figura 8 sumariza o processo de flexibilização dos limites populacionais impostos a cooperativas de crédito de livre admissão.

\begin{tabular}{|c|c|c|c|}
\hline & Publicação & Limite Mínimo & Limite Máximo \\
\hline Resolução no 3.106 $^{\mathbf{0}}$ & Junho 2003 & 100 mil habitantes & 750 mil habitantes \\
\hline Resolução no 3.321 & Outubro 2005 & 300 mil habitantes & 750 mil habitantes \\
\hline Resolução no 3.442 $^{\mathbf{0}}$ & Fevereiro 2007 & 300 mil habitantes & 2 milhões de hab. \\
\hline Resolução no 3.859 & Maio 2010 & 300 mil habitantes & acima de 2 milhões \\
\hline
\end{tabular}

Figura 8. Restrições populacionais de atuação das Cooperativas de Crédito de Livre Admissão Fonte: Elaboração própria a partir da legislação discutida.

No mesmo sentido, limitações geográficas e populacionais impostas às cooperativas de crédito de livre admissão estiveram diretamente ligadas às exigências de capital realizado e patrimônio líquido a elas impostas. Exigiram-se valores mais elevados de cooperativas atuando em áreas com maior número de habitantes, de modo a garantir sua solidez e proteger os potenciais cooperados. A Figura 9 indica como os valores das exigências de capital foram mantidos ou, em alguns casos, elevados.

\begin{tabular}{|c|c|c|c|c|}
\hline & $\begin{array}{c}\text { Resolução no } \\
3.106\end{array}$ & Resolução no 3.321 & $\begin{array}{c}\text { Resolução } \mathrm{n}^{0} \\
3.442\end{array}$ & $\begin{array}{c}\text { Resolução no } \\
3.859\end{array}$ \\
\hline Publicação & Junho 2003 & Outubro 2005 & Fevereiro 2007 & Maio 2010 \\
\hline $\begin{array}{l}\text { Cooperativas } \\
\text { de Crédito de }\end{array}$ & $\begin{array}{c}\mathrm{R} \$ 10.000 \text { (início)/ } \\
\mathrm{R} \$ 60.000(2\end{array}$ & $\begin{array}{l}\text { Abaixo } 300 \text { mil hab. } \\
\text { R } \$ 10.000 \text { (início)/ }\end{array}$ & $\begin{array}{l}\text { Até } 300 \text { mil hab.: } \\
\text { R } \$ 20.000 \text { (início)/ }\end{array}$ & $\begin{array}{l}\text { Até } 300 \text { mil hab.: } \\
\text { R } \$ 20.000 \text { (início)/ }\end{array}$ \\
\hline
\end{tabular}




\begin{tabular}{|c|c|c|c|c|}
\hline $\begin{array}{c}\text { Livre } \\
\text { Admissão }\end{array}$ & $\begin{array}{c}\text { anos)/ } \mathrm{R} \$ 120.000 \\
\text { (4 anos) - até cem } \\
\text { mil hab.; } \\
\mathrm{R} \$ 6.000 .000 \text { ou } \\
\mathrm{R} \$ 3.000 .000- \\
\text { acima cem mil } \\
\text { hab }\end{array}$ & $\begin{array}{c}\mathrm{R} \$ 120.000 \text { (4 anos) - } \\
\text { Norte, Nordeste e } \\
\text { Centro-Oeste } \\
\mathrm{R} \$ 50.000 \text { (início)/ } \\
\mathrm{R} \$ 500.000 \text { (4 anos) - } \\
\text { Sul e Sudeste } \\
\text { Acima } 300 \text { mil hab.: } \\
\mathrm{R} \$ 6.000 .000 \text { ou } \\
\mathrm{R} \$ 3.000 .000\end{array}$ & $\begin{array}{c}\mathrm{R} \$ 250.000 \text { (4 } \\
\text { anos) }\end{array}$ & $\begin{array}{c}\begin{array}{c}\mathrm{R} \$ 250.000 \text { (4 } \\
\text { anos) }\end{array} \\
\begin{array}{c}\text { Entre } 300 \text { mil e } \\
750 \text { mil hab.: }\end{array} \\
\text { R\$3.000.000 } \\
\underline{\text { Entre } 750 \text { mil e }} \\
\underline{\text { dois milhões de }} \\
\underline{\text { hab.: }} \\
\text { R } \$ 6.000 .000 \\
\underline{\text { Acima de dois }} \\
\text { milhões de hab.: } \\
\text { R } \$ 25.000 .000\end{array}$ \\
\hline
\end{tabular}

Figura 9. Evolução das exigências de Capital Realizado e Patrimônio Líquido para Cooperativas de Crédito de Livre Admissão

Fonte: Elaboração própria a partir da legislação discutida.

Finalmente, a Resolução $\mathrm{n}^{\mathrm{o}}$ 4.434, de agosto de 2015, foi responsável por classificar as cooperativas singulares em plenas, clássicas e de capital e empréstimo, de acordo com as operações por elas praticadas. As cooperativas plenas são aquelas cujas operações apresentam maior complexidade, estando sujeitas a controle prudencial mais exigente. Por outro lado, as cooperativas clássicas e as de capital e empréstimo apresentam baixa complexidade operacional e menor exposição a risco, estando sujeitas a regras prudenciais menos estritas. As cooperativas plenas estão autorizadas a captar recursos e depósitos de associados e aplicar recursos no mercado financeiro, entre outras atividades. Cooperativas clássicas desempenham atividades semelhantes, embora com atuação muito mais restrita e avessa a riscos no mercado financeiro. Cooperativas de capital e empréstimo, por sua vez, são impossibilitadas de captar recursos e depósitos de seus associados.

No que diz respeito a limites mínimos de capital integralizado e patrimônio líquido, cooperativas centrais de crédito e confederações de centrais passaram a ter de apresentar, respectivamente, duzentos mil reais e um milhão de reais para terem sua autorização de funcionamento. Cooperativas de capital e empréstimo ficaram sujeitas a integralização inicial de dez mil reais e PL de cem mil reais. Às clássicas foi definida exigência de integralização inicial semelhante, embora seu patrimônio líquido deva ser de trezentos mil reais. No caso das cooperativas de crédito clássicas não filiadas a 
central, esses valores aumentam para vinte mil reais e quinhentos mil reais. As cooperativas plenas, quando filiadas a central, devem apresentar integralização inicial de dois milhões e quinhentos mil reais e PL de vinte e cinco milhões de reais, sendo tais valores dobrados em caso de não filiação. A Resolução no 4.434 estabeleceu que todos os limites de patrimônio líquido deveriam ser apresentados em até cinco anos após a constituição dessas cooperativas de crédito, atingindo 50\% do limite mínimo final já no terceiro ano após iniciarem suas operações. Conforme apontado pela Figura 10, ao mesmo tempo em que as exigências de PL são bastante elevadas em um prazo mais longo, aquelas de integralização de capital mostram-se mais brandas.

\begin{tabular}{|c|c|c|}
\hline Modelo & Integralização & Patrimônio Líquido (5 anos) \\
\hline $\begin{array}{c}\text { Cooperativa de Capital e } \\
\text { Empréstimo }\end{array}$ & $\mathrm{R} \$ 10.000,00$ & $\mathrm{R} \$ 100.000,00$ \\
\hline Cooperativa Clássica & $\mathrm{R} \$ 10.000,00$ (filiadas) \\
$\mathrm{R} \$ 20.000,00$ (não filiadas) & $\begin{array}{c}\mathrm{R} \$ 300.000,00 \text { (filiadas) } \\
\mathrm{R} \$ 500.000,00 \text { (não filiadas) }\end{array}$ \\
\hline Cooperativa Plena & $\mathrm{R} \$ 2.500 .000,00$ (filiadas) & $\mathrm{R} \$ 25.000 .000,00$ (filiadas) \\
& $\mathrm{R} \$ 5.000 .000$ (não filiadas) & $\mathrm{R} \$ 50.000 .000,00$ (não filiadas) \\
\hline Cooperativa Central & $\mathrm{R} \$ 200.000,00$ & - \\
\hline Confederação & $1.000 .000,00$ & - \\
\hline
\end{tabular}

Figura 10. Exigências de Integralização e Patrimônio Líquido para os novos modelos de Cooperativa de Crédito

Fonte: Elaboração própria a partir da legislação discutida.

\subsubsection{Direcionamento de Recursos às Microfinanças}

Em junho de 2003, no contexto do chamado "pacote de microcrédito" do governo de Lula da Silva, foi promulgada a Medida Provisória $\mathrm{n}^{\mathrm{o}}$ 122, posteriormente convertida na Lei $\mathrm{n}^{\circ} 10.735$, de setembro de 2003. Doravante, bancos comerciais, bancos múltiplos com carteira comercial e a Caixa Econômica Federal, bem como cooperativas de crédito de livre admissão e cooperativas de crédito de pequenos empresários, microempresários e microempreendedores passaram a estar sujeitos à exigência de direcionamento de depósitos à vista para operações de microcrédito. Essa nova regulamentação buscou dar o passo inicial para inserir esse conjunto de instituições no mercado nacional de microcrédito, ainda que de maneira mandatória, refletindo a busca do governo por ampliar o acesso a serviços bancários por parte da população de menor renda. 
As operações de microcrédito sujeitas à exigência seriam destinadas à população de baixa renda, e voltadas tanto para consumo quanto para atividades produtivas. Os juros seriam limitados, e recursos não aplicados seriam recolhidos sem remuneração pelo Banco Central do Brasil, permanecendo indisponíveis para a instituição penalizada.

A Resolução $n^{\circ} 3.109$, de julho de 2003, regulamentou as disposições referentes à exigibilidade de direcionamento de recursos, fixando em $2 \%$ do saldo de depósitos à vista captados pela instituição financeira, com verificações anuais. No mesmo sentido, taxas de juros foram limitadas a $2 \%$ ao mês, com taxa de abertura de crédito (TAC) máxima de $2 \%$ para pessoas físicas e $4 \%$ para microempreendedores. O prazo das operações seria de 120 dias, e o limite máximo concedido por operação foi definido em quinhentos reais para pessoas físicas e mil reais para microempreendedores.

A Resolução $n^{\circ} 3.109$ estabeleceu de forma pormenorizada os potenciais beneficiários das operações, sendo estes pessoas físicas detentoras de contas especiais de depósitos ou titulares de contas e aplicações com saldo mensal médio de até mil reais, pessoas físicas e jurídicas aptas a contratar operações de SCMs, conforme regulamentação própria, e pessoas físicas de baixa renda, conforme definido pela Lei Complementar $\mathrm{n}^{\circ}$ 111. Tendo em vista possíveis dificuldades em termos de documentação pelo público-alvo dessas operações de microcrédito, facultou-se a contratação das operações previstas por meio de procedimentos simplificados de confecção de ficha cadastral e de contratos.

A exigibilidade poderia ser cumprida também por meio do repasse de recursos, via depósitos interfinanceiros vinculados a operações de microfinanças (DIM), a instituições como SCMs, para que estas realizassem as operações de microcrédito previstas na Resolução. Da mesma forma, foi possibilitada a aquisição de créditos provenientes de operações realizadas por SCMs, OSCIPs dedicadas a atividades de concessão de crédito a microempreendedores e a ONGs cujos estatutos previssem a realização de operações de microcrédito.

Entre outubro de 2003 e julho de 2004, foram realizadas diversas alterações na regulamentação vigente. A Resolução n 3.128 ampliou o limite de crédito por operação para pessoa física para seiscentos reais, possibilitando também a aquisição de operações realizadas por entidades, fundos e programas voltados para microcrédito para fins de cumprimento da exigibilidade. A Resolução $n^{\circ} 3.212$ excluiu do cálculo da exigibilidade os depósitos à vista captados por instituições financeiras públicas, federais 
e estaduais, dos próprios governos ou autarquias e sociedades de economia mista a eles relacionados, bem como aqueles captados de municípios da mesma Unidade Federativa da instituição. Finalmente, a Resolução n 3.220 alterou a periodicidade da verificação da exigibilidade de anual para mensal.

A Resolução $n^{\circ}$ 3.229, de agosto de 2004, reformulou a regulamentação existente, de modo a incluir na contabilização da exigência as operações de microcrédito produtivo orientado, considerado aquele concedido para atender necessidades financeiras de micro e pequenos empreendimentos, formais ou informais, através de metodologia de relacionamento direto com o empreendedor no local de sua atividade econômica. Outrossim, tal contato deveria ser realizado por profissionais com treinamento específico, ao longo de todo o período de contrato e com os valores do crédito definidos previamente a partir da capacidade de endividamento do tomador. As taxas de juros para tais operações não poderiam exceder $4 \%$ ao mês, tanto para aquelas de repasses de recursos quanto àquelas adquiridas de SCMs, OSCIPs e ONGs. Operações de repasse ou aquisição poderiam compor até $30 \%$ do total para fins de contabilização da exigibilidade.

Em agosto de 2005, a Resolução ${ }^{\circ} 3.310$ restringiu a aplicação da exigibilidade somente a bancos comerciais, bancos múltiplos com carteira comercial e à Caixa Econômica Federal. À lista de possíveis beneficiários foram acrescidas microempresas, pessoas físicas com pequenos empreendimentos profissionais, comerciais ou industriais e pessoas físicas e jurídicas empreendedoras de atividades produtivas de pequeno porte, com renda bruta de até sessenta mil mensais. Taxas de juros foram limitadas a $2 \%$ ao mês para a maioria das operações e $4 \%$ ao mês no caso daquelas de microcrédito produtivo orientado, sendo a taxa de abertura de crédito de $2 \%$ para pessoas físicas, $4 \%$ para pessoas jurídicas e variando entre $1 \%$ e $3 \%$ em operações de MPO.

Embora o valor do crédito tenha se mantido restrito a seiscentos reais quando concedido a pessoas físicas, seu valor máximo passou para mil e quinhentos reais para microempreendedores. Operações de microcrédito produtivo orientado poderiam atingir cinco mil reais, sendo que até $20 \%$ do total de operações poderia ser composto por operações de MPO com limite máximo de dez mil reais.

Alterando a regulamentação relativa aos beneficiários das operações sujeitas à exigibilidade, a Resolução $n^{\circ} 3.442$, de dezembro de 2006, ampliou para três mil reais o saldo médio mensal de contas de depósitos de pessoas físicas. No mesmo sentido, o 
limite máximo de operações de microcrédito concedidas passou a ser de mil reais para pessoas físicas, três mil reais para microempreendedores e dez mil reais para microcrédito produtivo orientado. Três anos depois, em março de 2009, a Resolução $n^{\circ}$ 3.706 promoveu nova alteração de tais limites, dessa vez para dois mil reais para pessoas físicas, cinco mil reais para microempreendedores e quinze mil reais para operações de microcrédito produtivo orientado.

Assim, conforme disposto na Figura 11, as principais alterações referentes à exigibilidade de direcionamento de recursos ao longo do tempo ocorreram nos limites de crédito impostos às operações.

\begin{tabular}{|c|c|c|c|c|c|}
\hline & $\begin{array}{c}\text { Resolução } \\
\mathbf{n}^{\mathbf{o}} \mathbf{3 . 1 0 9}\end{array}$ & $\begin{array}{c}\text { Resolução } \\
\mathbf{n}^{\mathbf{0}} \mathbf{3 . 1 2 8}\end{array}$ & $\begin{array}{c}\text { Resolução no } \\
\mathbf{3 3 1 0}\end{array}$ & $\begin{array}{c}\text { Resolução n } \\
\mathbf{3 . 4 4 2}\end{array}$ & $\begin{array}{c}\text { Resolução } \\
\mathbf{n}^{\mathbf{0}} \mathbf{3 . 7 0 6}\end{array}$ \\
\hline Publicação & $\mathrm{Julho} 2003$ & Out. 2003 & Ago. 2005 & Mar. 2006 & Mar. 2009 \\
\hline Pessoas Físicas & $\mathrm{R} \$ 500$ & $\mathrm{R} \$ 600$ & $\mathrm{R} \$ 600$ & $\mathrm{R} \$ 1.000$ & $\mathrm{R} \$ 2.000$ \\
\hline Microempreendedores & $\mathrm{R} \$ 1.000$ & $\mathrm{R} \$ 1.000$ & $\mathrm{R} \$ 1.500$ & $\mathrm{R} \$ 3.000$ & $\mathrm{R} \$ 5.000$ \\
\hline $\begin{array}{c}\text { Microcrédito Produtivo } \\
\text { Orientado }\end{array}$ & - & - & $\mathrm{R} \$ 10.000($ até & & $\mathrm{R} \$ 15.000$ \\
& & & $\mathrm{R} \$ 5.000$ & & $\mathrm{R} \$ 10.000$ \\
\end{tabular}

Figura 11. Evolução do valor máximo permitido por operação de microcrédito sujeita à exigibilidade de direcionamento de depósitos à vista

Fonte: Elaboração própria a partir da legislação discutida

Finalmente, em agosto de 2011, a Resolução $\mathrm{n}^{\circ} 4.000$ consolidou a regulamentação referente ao direcionamento de parcelas dos recursos provenientes de depósitos à vista para operações de microcrédito. Sua principal alteração foi a exigência de que $80 \%$ do saldo sujeito ao direcionamento fosse destinado a operações de microcrédito produtivo orientado, com prazo de adequação até janeiro de 2013.

\subsubsection{Programa Nacional de Microcrédito Produtivo Orientado}

A constituição do Programa Nacional de Microcrédito Produtivo Orientado (PNMPO) pela Medida Provisória $\mathrm{n}^{\circ}$ 226, de novembro de 2004, visava a universalização do acesso ao microcrédito por empreendedores excluídos do Sistema Financeiro Nacional e a criação de novos postos de trabalho e geração de renda (COELHO e PRANDINI, 2009: pp. 33-35). 
Inserido no âmbito do Ministério do Trabalho e Emprego (MTE), considerou-se microcrédito produtivo orientado todo crédito voltado ao atendimento das demandas financeiras de pessoas físicas e jurídicas dedicadas a atividades produtivas de pequena escala, mediante emprego de metodologia específica, envolvendo o relacionamento direto com empreendedores no local de execução da atividade econômica. O atendimento ao tomador final de crédito deveria ser realizado de forma contínua ao longo de todo o período de contrato, por profissionais especializados, responsáveis por definir, mediante análise prévia, a capacidade de endividamento do tomador.

Inicialmente foram destinados ao Programa recursos provenientes do Fundo de Amparo ao Trabalhador (FAT) e da exigibilidade de direcionamento de depósitos à vista, regida pela Lei $n^{\circ}$ 10.735. Poderiam operar com os recursos do FAT somente instituições financeiras federais, enquanto bancos comerciais, bancos múltiplos com carteira comercial e a Caixa Econômica Federal atuariam com recursos originários da exigibilidade. Essas instituições foram classificadas como Instituições Financeiras Operadoras (IFOs) no âmbito do PNMPO. Por sua vez, definiram-se como Instituições de Microcrédito Produtivo Orientado (IMPOs) as cooperativas singulares de crédito, agências de fomento, SCMs e OSCIPs, às quais as IFOs poderiam repassar recursos ou das quais poderiam adquirir operações de microcrédito produtivo orientado. Ainda no âmbito da Medida Provisória $n^{\circ} 226$, facultou-se a realização de operações com o emprego de garantias alternativas, possibilitando o uso de metodologia de aval solidário.

O Decreto $\mathrm{n}^{\circ}$ 5.288, de novembro de 2004, definiu como beneficiários do PNMPO as pessoas físicas e jurídicas dedicadas a atividades produtivas de pequena escala e com renda bruta anual de até sessenta mil reais. Autorizou também, de forma expressa, a aplicação de metodologia de aval solidário, com grupos formados por um mínimo de três participantes, e estabeleceu o emprego de agentes de crédito pelas IMPOs como forma de garantir o bom uso dos recursos concedidos aos tomadores finais.

A Lei $\mathrm{n}^{\circ} 11.110$, de abril de 2005, consolidou as disposições vigentes acerca do PNMPO, prevendo também que bancos de desenvolvimento, agências de fomento, bancos cooperativos e centrais de cooperativas de crédito atuassem como repassadores de recursos de IFOs para IMPOs. No mesmo sentido, estabeleceu que as IFOs atuariam 
no PNMPO via aquisição de operações, repasse de recursos ou concessão de mandato para IMPOs.

Em agosto de 2005, a Resolução $\mathrm{n}^{\circ} 449$ do CODEFAT classificou como Agentes de Intermediação (AGIs) os bancos de desenvolvimento, agências de fomento, bancos cooperativos e cooperativas centrais de crédito, que poderiam atuar no repasse de recursos de IFOs para IMPOs. Ademais, constituiu duas linhas de crédito envolvendo recursos do FAT. A primeira delas, de repasse, teria as IMPOs beneficiadas por recursos direta ou indiretamente fornecidos por IFOs, sendo o teto de repasse equivalente a dois milhões de reais, com liberação parcelada e condicionada à aplicação de um mínimo de $80 \%$ da parcela anterior em operações de microcrédito. O prazo das operações seria de até 96 meses.

Já a segunda envolveria a concessão direta de microcrédito produtivo orientado por Instituições Financeiras Operadoras aos tomadores finais. Logo, seria destinada a bens, serviços e capital de giro para empreendimentos, com teto financiável de até dez mil reais embora $80 \%$ devessem obrigatoriamente ser empregados em operações de até cinco mil reais. Seu prazo de financiamento seria de até vinte e quatro meses, com taxas de juros de $4 \%$ ao mês e taxa de abertura de crédito (TAC) variável entre $1 \%$ e $3 \%$, conforme o prazo da operação.

Em outubro de 2006, a Resolução nº 511 do CODEFAT buscou uma melhor estruturação da aplicação de recursos do FAT destinados ao PNMPO, que passou a ser classificada em quatro modalidades. IMPOs ou IFOs poderiam realizar a contratação direta com o microempreendedor; IMPOs poderiam conceder crédito ao tomador final em nome de IFOs, mediante autorização para operações de mandato. Operações realizadas com o repasse de recursos de IFOs para IMPOs, de forma direta ou por Agentes de Intermediação. Finalmente, IFOs poderiam adquirir operações de microcrédito produtivo orientado realizadas por IMPOs.

O limite máximo financiável por pessoas físicas e jurídicas permaneceu em dez mil reais, sendo facultada a concessão de três mil reais por associado em caso de empreendimentos coletivos e de economia solidária, até o limite de 50\% da renda bruta anual do empreendimento. A taxa de juros máxima, mantida em $4 \%$ ao mês, foi alterada pela Resolução $n^{\circ} 611$ do CODEFAT, de julho de 2009, para 1,32\%. Em outubro de 2013, a Resolução $n^{\circ} 720$ do CODEFAT alterou para quinze mil reais o teto financiável 
para pessoas físicas e jurídicas. A Figura 12 apresenta as principais mudanças realizadas pelo CODEFAT em relação a aplicação de recursos do FAT no PNMPO:

\begin{tabular}{|c|c|c|c|c|}
\hline & Resolução no 449 & Resolução nº 511 & Resolução nº 611 & Resolução no 720 \\
\hline Publicação & Agosto de 2005 & Outubro de 2006 & Julho de 2009 & Outubro de 2013 \\
\hline $\begin{array}{l}\text { Limite por } \\
\text { Cliente }\end{array}$ & $\begin{array}{c}\mathrm{R} \$ 10.000 \text { (20\% das } \\
\text { operações); } \\
\mathrm{R} \$ 5.000 \text { (demais) }\end{array}$ & $\begin{array}{c}\mathrm{R} \$ 10.000 \text { (20\% das } \\
\text { operações); } \\
\mathrm{R} \$ 5.000 \text { (demais); } \\
\mathrm{R} \$ 3.000 \text { (por } \\
\text { associado para } \\
\text { empreendimentos } \\
\text { coletivos }\end{array}$ & $\begin{array}{c}\mathrm{R} \$ 10.000 \text { ( } 20 \% \text { das } \\
\text { operações); } \\
\mathrm{R} \$ 5.000 \text { (demais); } \\
\mathrm{R} \$ 3.000 \text { (por } \\
\text { associado para } \\
\text { empreendimentos } \\
\text { coletivos }\end{array}$ & $\mathrm{R} \$ 15.000$ \\
\hline $\begin{array}{c}\text { Taxa de } \\
\text { Juros }\end{array}$ & $4 \%$ & $4 \%$ & $1,32 \%$ & $1,32 \%$ \\
\hline
\end{tabular}

Figura 12. Evolução regulatória para operações com recursos do FAT no âmbito do PNMPO Fonte: Elaboração própria a partir da legislação discutida no texto

Alterando disposições anteriores, o Decreto $\mathrm{n}^{\circ}$ 6.607, de outubro de 2008, aumentou de sessenta mil reais para cento e vinte mil reais a renda bruta anual máxima para beneficiários do PNMPO. Por sua vez, a Lei $n^{\circ} 12.249$, de junho de 2010, ampliou a gama de recursos possivelmente direcionados ao PNMPO, abrangendo a partir de então os provenientes do FAT, da exigibilidade de repasse de parcela de depósitos à vista para operações de microcrédito, do orçamento geral da União e de Fundos Constitucionais de Financiamento.

Em setembro de 2017, com o intuito de reformular o Programa, foi editada a Medida Provisória $n^{\circ}$ 802. O conjunto de beneficiários apontado por essa nova roupagem do PNMPO passou a ser de pessoais naturais e jurídicas dedicadas a atividades produtivas urbanas ou rurais, organizadas individual ou coletivamente e com receita ou renda bruta anual de até duzentos mil reais. Desse modo, a nova regulamentação definiu microcrédito produtivo orientado como todo aquele concedido para financiamento de atividades produtivas, com metodologia específica e observada preferência de relacionamento direto com empreendedores. A Figura 13 aponta as alterações da renda bruta anual máxima para os beneficiários do PNMPO ao longo tempo, evidenciando uma tendência que parece buscar atrair empreendedores com renda um pouco mais elevada para o Programa. 


\begin{tabular}{|c|c|c|c|}
\hline Publicação & Decreto $^{\mathbf{0}} \mathbf{5 . 2 8 8}$ & Decreto $^{\mathbf{0}} \mathbf{6 . 6 0 7}$ & Medida Provisória $^{\mathbf{0}} \mathbf{8 0 2}$ \\
\hline $\begin{array}{c}\text { Renda Bruta Anual } \\
\text { Beneficiários }\end{array}$ & $\mathrm{R} \$ 60.000$ & $\mathrm{R} \$ 120.000$ & $\mathrm{Setembro} \mathrm{de} 2017$ \\
\hline
\end{tabular}

Figura 13. Evolução dos limites de renda bruta anual para beneficiários do PNMPO

Fonte: Elaboração própria a partir da legislação discutida

Finalmente, o Decreto $\mathrm{n}^{\circ}$ 9.161, de 26 de setembro de 2017, alterou a metodologia específica para concessão de microcrédito produtivo orientado. A principal alteração em relação a metodologia empregada até então foi a possibilidade de o agente de crédito realizar contatos posteriores à contratação da operação, de forma não presencial, reduzindo assim os custos de acompanhamento.

\subsection{Resultados}

Tomando como base as hipóteses inicialmente discutidas acerca dos efeitos da regulação financeira sobre o setor de microfinanças, a análise do desenvolvimento regulamentar brasileiro permite a delimitação de alguns dos resultados esperados em termos de estrutura do setor, alcance e autossustentabilidade financeira das instituições operadoras de microcrédito no Brasil.

Para as Organizações da Sociedade Civil de Interesse Público (OSCIPs), esperase que a isenção de limites de juros, definida a partir de julho de 1999, tenha resultado em um maior número de instituições atuantes sob este modelo. Disposição de agosto do mesmo ano possibilitou às OSCIPs se transformarem em Sociedades de Crédito ao Microempreendedor (SCMs), traçando uma trajetória a ser adotada para se atingir o status de instituição regulada. Ambos os modelos compartilhavam a isenção de juros e a impossibilidade de captação de depósitos, embora as exigências regulatórias em vigor fossem mais restritas para as SCMs. Nesse sentido, não houve registro de instituições que fizeram tal opção.

No que diz respeito às Sociedades de Crédito ao Microempreendedor e Empresa de Pequeno Porte (SCMEPPs), as exigências de capital realizado e de patrimônio líquido passaram de cem mil reais para duzentos mil reais a partir de maio de 2008. Tendo em vista que a exigência, já considerada elevada na comparação com cooperativas de crédito, por exemplo, foi ampliada, espera-se observar um número 
limitado de instituições organizadas sob este modelo. Possivelmente, esse efeito teria sido até certo ponto minimizado pela concessão, em fins de 2007, de permissão para prestação de serviços também a empresas de pequeno porte, ampliando a gama de atuação das SCMEPPs e atraindo novos atores para esse tipo institucional.

Em relação às cooperativas de crédito de livre admissão, houve ampliação paulatina de seus limites geográficos e populacionais de atuação entre 2003 e 2010, passando de regiões com cem mil habitantes para regiões com trezentos mil habitantes para instituições recém-criadas e de setecentos e cinquenta mil habitantes para dois milhões de habitantes para instituições com mais tempo de funcionamento. Mediante tal flexibilização, espera-se um maior número de instituições atuando sob esse modelo institucional, bem como número mais elevado de clientes atendidos e maior autossustentabilidade financeira, esta em decorrência de ganhos de escala.

Ainda acerca das cooperativas de crédito, houve flexibilização das exigências de capital de entrada e de patrimônio líquido para todos os modelos ao longo do tempo, exceção feita às cooperativas de crédito de livre admissão. Logo, em termos gerais, espera-se observar um grande número de cooperativas de crédito de menor porte, embora com um número limitado de cooperativas de livre admissão de maior porte. Contudo, o relaxamento de disposições populacionais e geográficas, acima mencionado, poderia minimizar os efeitos das exigências mais restritivas de capital e patrimônio líquido.

Em termos da exigibilidade de direcionamento de recursos para operações de microfinanças, a limitação das taxas de juros a $2 \%$ ao mês poderiam dificultar a cobertura de custos das instituições envolvidas, afetando negativamente sua autossustentabilidade financeira e gerando poucos incentivos para movimentos de downscaling. Essa talvez seja uma das razões para a baixa adesão à norma, com recursos sendo recolhidos compulsoriamente ao Banco Central do Brasil sem remuneração. Porém, esse quadro teria sido alterado a partir de agosto de 2004, quando facultou-se a realização de operações de microcrédito produtivo orientado para fins de cumprimento da exigibilidade com taxas de $4 \%$ ao mês. Assim, espera-se um maior envolvimento de instituições sujeitas à exigibilidade com operações de microcrédito, ainda que via repasses ou aquisição. No âmbito do PNMPO, em contrapartida, limites de juros aplicados a operações de microcrédito produtivo orientado realizadas com 
recursos do FAT foram reduzidos, esperando-se efeito oposto. A Figura 14 resume os resultados esperados em termos de estrutura do setor de microcrédito no Brasil:

\begin{tabular}{|c|c|c|}
\hline \multicolumn{3}{|c|}{ Estrutura do Setor de Microcrédito } \\
\hline Tipo Institucional & Regulação Encontrada & Efeito Esperado \\
\hline OSCIPs & Isenção de limite de juros & Número maior de instituições \\
\hline \multirow[b]{2}{*}{ SCMEPPs } & $\begin{array}{c}\text { Ampliação de exigência de } \\
\text { capital e de patrimônio líquido }\end{array}$ & Número limitado de instituições \\
\hline & $\begin{array}{c}\text { Ampliação da gama de clientes } \\
\text { disponível (empresas de pequeno } \\
\text { porte) }\end{array}$ & $\begin{array}{l}\text { Aumento do número de } \\
\text { instituições }\end{array}$ \\
\hline \multirow{2}{*}{$\begin{array}{c}\text { Cooperativas de Crédito de } \\
\text { Livre Admissão }\end{array}$} & $\begin{array}{c}\text { Ampliação dos limites } \\
\text { populacionais e geográficos }\end{array}$ & $\begin{array}{c}\text { Aumento no número de } \\
\text { instituições }\end{array}$ \\
\hline & $\begin{array}{l}\text { Aumentos nas exigências de } \\
\text { capital e de patrimônio líquido }\end{array}$ & $\begin{array}{c}\text { Número limitado de instituições } \\
\text { de maior porte }\end{array}$ \\
\hline Cooperativas de Crédito & $\begin{array}{l}\text { Flexibilização das exigências de } \\
\text { capital e de patrimônio líquido }\end{array}$ & $\begin{array}{l}\text { Número elevado de instituições } \\
\text { de menor porte }\end{array}$ \\
\hline $\begin{array}{c}\text { Exigibilidade de } \\
\text { Direcionamento de Depósitos à } \\
\text { Vista }\end{array}$ & $\begin{array}{c}\text { Ampliação dos limites de juros } \\
\text { para microcrédito produtivo } \\
\text { orientado }\end{array}$ & $\begin{array}{l}\text { Aumento no número de } \\
\text { instituições atuantes }\end{array}$ \\
\hline PNMPO & $\begin{array}{l}\text { Redução dos limites de juros em } \\
\text { operações com recursos do FAT }\end{array}$ & $\begin{array}{l}\text { Redução no número de } \\
\text { instituições atuantes }\end{array}$ \\
\hline
\end{tabular}

Figura 14. Resultados esperados em termos de estrutura do setor de microcrédito brasileiro por tipo de regulação

Fonte: Elaboração própria a partir da legislação discutida

Para as OSCIPs, a principal alteração na regulamentação foi a ampliação de suas possíveis fontes de financiamento. Inicialmente limitadas a doações, empréstimos e recursos de Termos de Parceria estabelecidos com o poder público, foi facultado, a partir de julho de 2003, o recebimento de repasses do direcionamento de depósitos à vista para operações de microcrédito. Dessa forma, espera-se maior autossustentabilidade financeira dessas instituições, bem como uma ampliação da amplitude de seu alcance. No entanto, a baixa adesão à exigibilidade e os limites de juros definidos em $2 \%$ ao mês para essas operações pode ter minimizado os efeitos esperados. 
No que tange as SCMEPPs, a ampliação de seu foco de atendimento com a reformulação do modelo a partir de setembro de 2007, passando a atender também empresas de pequeno porte, contribuiria para a atração de recursos para o modelo e para um maior número de clientes a serem atendidos. Nesse sentido, espera-se observar uma ampliação do alcance e da autossustentabilidade financeira desse modelo institucional.

Embora as exigências de diversificação de riscos por clientes estejam até certo ponto ausentes na literatura previamente discutida, teoriza-se que tais restrições limitariam a realização de operações de montantes mais elevados, favorecendo um maior alcance, mas sendo prejudicial em termos de sustentabilidade financeira ao elevar os custos com uma série de operações de pequena escala. Com a flexibilização concedida às SCMEPPs em 2008, cujo limite prévio de dez mil reais por operações foi substituído pelo equivalente a 5\% do patrimônio líquido da instituição, prevê-se uma maior autossustentabilidade financeira dessas instituições, embora com possíveis efeitos negativos sobre o alcance.

Finalmente, limites de endividamento para as SCMEPPs foram alterados em maio de 2008, passando de cinco para dez vezes o patrimônio líquido da instituição. Desse modo, permitiu-se maior alavancagem, gerando maior atratividade a investidores e maior possibilidade de lucro. Espera-se, portanto, um possível aumento de sua autossustentabilidade financeira e de seu alcance.

Para as cooperativas de crédito, limites de endividamento também foram alterados de cinco para dez vezes o patrimônio líquido ajustado das cooperativas singulares filiadas a cooperativas centrais, embora tal mudança tenha ocorrido no ano 2000. Desse modo, espera-se efeito semelhante de ampliação da autossustentabilidade financeira e do alcance em decorrência das maiores possibilidades de alavancagem.

Em 2005, foram alterados também os limites referentes a diversificação de risco para as cooperativas de crédito. Sendo assim, cooperativas singulares filiadas a cooperativas centrais passaram a poder realizar operações de até $15 \%$ de seu patrimônio líquido (PL) por cliente, frente aos 10\% anteriores. Para cooperativas não filiadas, esse valor passou de 5\% para 10\% do PL, enquanto cooperativas centrais ficaram limitadas a $25 \%$ do patrimônio líquido para operações de mercado e a $20 \%$ para operações de crédito. Por conseguinte, antecipa-se ganhos em termos de autossustentabilidade financeiro devido à possibilidade de se realizar operações com valores mais elevados, sendo o alcance prejudicado em decorrência. 
Acerca da exigibilidade de direcionamento de depósitos à vista para microcrédito, o teto por operação foi paulatinamente aumentado. Os quinhentos reais para pessoas físicas e mil reais para microempreendedores, permitidos em 2003, passaram a ser, respectivamente, dois mil reais e cinco mil reais em 2009, com as operações de microcrédito produtivo podendo atingir o valor de quinze mil reais.. Destarte, espera-se uma maior autossustentabilidade financeira das instituições envolvidas nessas operações, com possíveis perdas quanto à profundidade do alcance.

Por fim, para o PNMPO, operações realizadas com recursos do FAT tiveram seus limites ampliados de dez mil reais em 2005, ainda que tal valor pudesse ser aplicado somente a vinte por cento das operações realizadas, para quinze mil reais por cliente no ano de 2013. Um dos efeitos esperados seria a migração para clientes de maior renda, reduzindo o alcance das instituições que empregam tais recursos no âmbito do Programa. A contrapartida seriam os ganhos em termos de autossustentabilidade financeira. Reforçando essa tendência de concentração em clientes com maiores recursos, a renda bruta anual máxima dos beneficiários do PNMPO passou de sessenta mil reais em 2004 para cento e vinte mil reais em 2008, sendo fixada em duzentos mil reais no ano de 2017. A Figura 15 indica os resultados esperados em termos de alcance e autossustentabilidade financeira.

\begin{tabular}{|c|c|c|}
\hline \multicolumn{2}{|c|}{ Alcance e Autossustentabilidade Financeira do Setor de Microcrédito } \\
\hline \multirow{2}{*}{ Tipo Institucional } & Regulação Encontrada & Resultado Esperado \\
\hline \multirow{2}{*}{ OSCIPs } & $\begin{array}{c}\text { Ampliação das fontes de } \\
\text { financiamento }\end{array}$ & $\begin{array}{c}\text { Maior autossustentabilidade } \\
\text { financeira e maior alcance }\end{array}$ \\
\hline \multirow{2}{*}{ SCMEPPs } & $\begin{array}{c}\text { Ampliação da gama de clientes } \\
\text { disponível (empresas de pequeno }\end{array}$ & $\begin{array}{c}\text { Maior autossustentabilidade } \\
\text { financeira e maior alcance }\end{array}$ \\
& plexibilização dos limites de & Maior autossustentabilidade \\
& diversificação de risco & financeira e menor alcance \\
\cline { 2 - 3 } & Ampliação dos limites de & Maior autossustentabilidade \\
& endividamento & financeira e maior alcance \\
\cline { 2 - 3 } & Ampliação dos limites de & Maior autossustentabilidade \\
& endividamento & financeira e maior alcance \\
\hline \multirow{2}{*}{ Cooperativas de Crédito } & Flexibilização dos limites de & Maior autossustentabilidade \\
& diversificação de risco & financeira e menor alcance \\
\cline { 2 - 3 } & Aumento do teto máximo & Maior autossustentabilidade \\
\hline
\end{tabular}




\begin{tabular}{|c|c|c|}
\hline de Depósitos à Vista & concedido por operação & $\begin{array}{c}\text { financeira e menor alcance } \\
\text { (profundidade) }\end{array}$ \\
\hline \multirow{2}{*}{ PNMPO } & $\begin{array}{c}\text { Ampliação do teto máximo } \\
\text { concedido por operação com } \\
\text { recursos do FAT }\end{array}$ & $\begin{array}{c}\text { Maior autossustentabilidade } \\
\text { financeira e menor alcance } \\
\text { (profundidade) }\end{array}$ \\
\cline { 2 - 3 } & $\begin{array}{c}\text { Aumenta da renda bruta anual } \\
\text { máxima dos beneficiários }\end{array}$ & $\begin{array}{c}\text { Maior autossustentabilidade } \\
\text { financeira e menor alcance } \\
\text { (profundidade) }\end{array}$ \\
\hline
\end{tabular}

Figura 15. Resultados esperados em termos de alcance e autossustentabilidade financeira do setor de microcrédito brasileiro por tipo de regulação

Fonte: Elaboração própria a partir da legislação discutida

\subsubsection{Análise Empírica}

Os dados empíricos referentes a instituições que atuam no setor de microcrédito no Brasil foram levantados a partir das atualizações mensais disponibilizadas pelo Banco Central do Brasil acerca da Evolução do Sistema Financeiro nacional. Da mesma forma, foram empregados os relatórios do produzidos pelo Ministério do Trabalho e do Emprego acerca do Programa Nacional de Microcrédito Produtivo Orientado.

É importante destacar as dificuldades no levantamento de dados, bem como as limitações referentes às fontes utilizadas. Ao contrário do caso mexicano, dados relativos à autossustentabilidade financeira das instituições envolvidas, na maioria dos casos, não estavam disponíveis. O mesmo ocorre a respeito da profundidade do alcance. Ainda, a composição dos relatórios produzidos pelo MTE acerca do PNMPO foi alterada ao longo dos anos, implicando em dados faltantes para algumas das séries disponibilizadas.

Com exceção da Figura 16, todas aquelas envolvendo valores monetários foram deflacionadas com o IPCA-geral, sendo atualizadas de acordo com os valores reais correspondentes à última data registrada na série de dados.

\subsubsection{Estrutura do Setor}

No que tange o tamanho relativo do setor de microcrédito no Brasil, a Figura 16 indica um montante total de cinco bilhões e trezentos milhões de reais concedidos de acordo com dados do Banco Central do Brasil na data-base de dezembro de 2013. Em contraposição, o volume concedido via cheque especial é quase quatro vezes maior, 
enquanto a modalidade de crédito consignado, com o segundo maior montante, totalizava cerca de duzentos e vinte e um bilhões e novecentos milhões de reais.

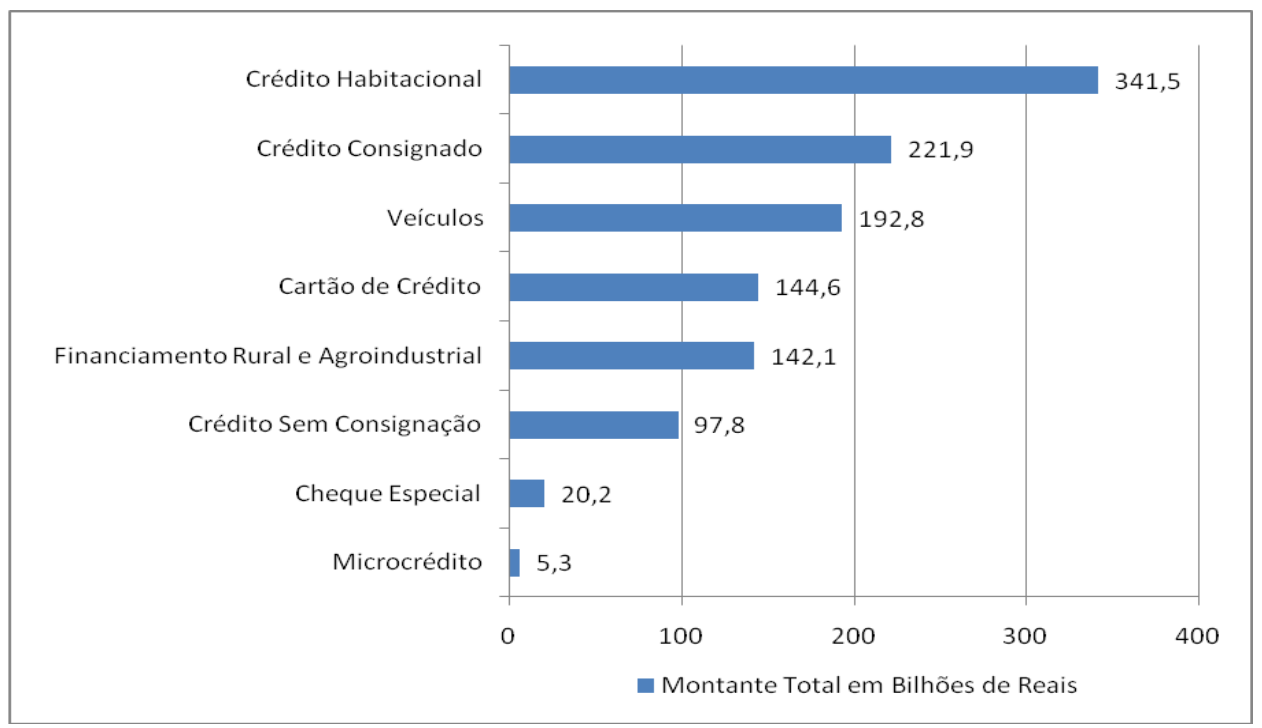

Figura 16. Valor total de carteira para modalidades de crédito pessoa física - dezembro de 2013

Fonte: BACEN. Panorama do Microcrédito. Série Cidadania Financeira - Estudos sobre Educação, Proteção e Inclusão. Edição nº1. Jul. 2015, p. 8.

Em termos do número de OSCIPs atuantes no setor de microcrédito, os dados mais confiáveis para avaliar sua evolução ao longo do tempo são referentes ao PNMPO, ainda que provavelmente subestimem o número total dessas instituições. A Figura 17 indica que o número de OSCIPs atuantes via Programa Nacional de Microcrédito Produtivo Orientado apresentou crescimento significativo apenas nos três primeiros anos da base de dados, tendo passado de quarenta instituições em 2005 para noventa no segundo semestre de 2006. No segundo semestre de 2007 elas já totalizavam cento e três, tendo atingido cento e vinte e quatro no segundo semestre de 2008. Desde então, o total de instituições envolvidas no PNMPO cresceu com maior lentidão, ainda que de modo constante, tendo se estabilizado acima de cento e sessenta em 2014 e 2015, últimos anos da série. 


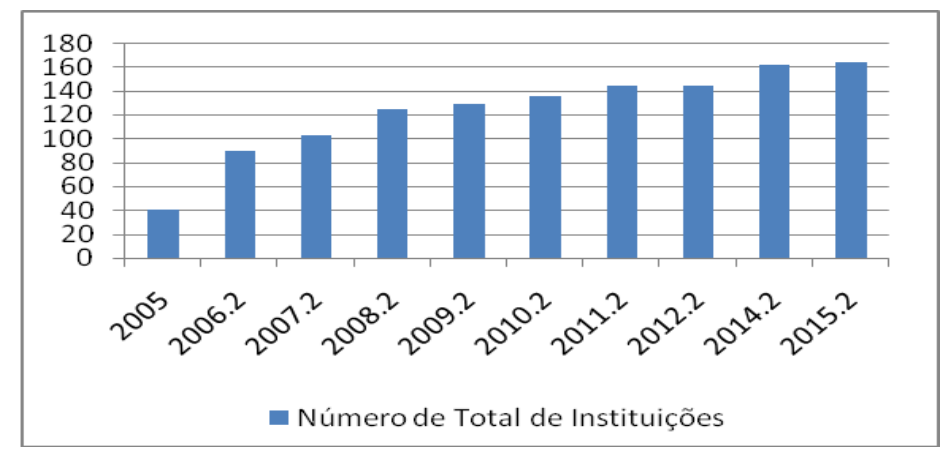

Figura 17. Evolução semestral no número total de OSCIPs atuando via PNMPO

Fonte: Elaboração própria a partir de BRASIL. Ministério do Trabalho e do Emprego. PNMPO informações gerenciais do Programa Nacional de Microcrédito Produtivo Orientado. Disponível em: http://portalfat.mte.gov.br/programas-e-acoes-2/programa-nacional-do-microcredito-produtivo-orientadopnmpo/sistema-de-informacoes-do-pnmpo/ Acesso: 11/11/2017.

No que tange as SCMEPPs, a Figura 18 aponta para um forte aumento no número de instituições operando sob esse modelo ao longo dos primeiros anos de sua constituição. De três em 1999, o total passou para quarenta e nove em 2003, tendo atingido o ápice de cinquenta e seis instituições registradas em 2006. A partir de então houve ligeira queda, e o número de SCMEPPs estabilizou-se próximo ao patamar das quarenta instituições. Para o ano de 2017 foram informadas trinta e oito Sociedades de Crédito ao Microempreendedor e à Pequena Empresa.

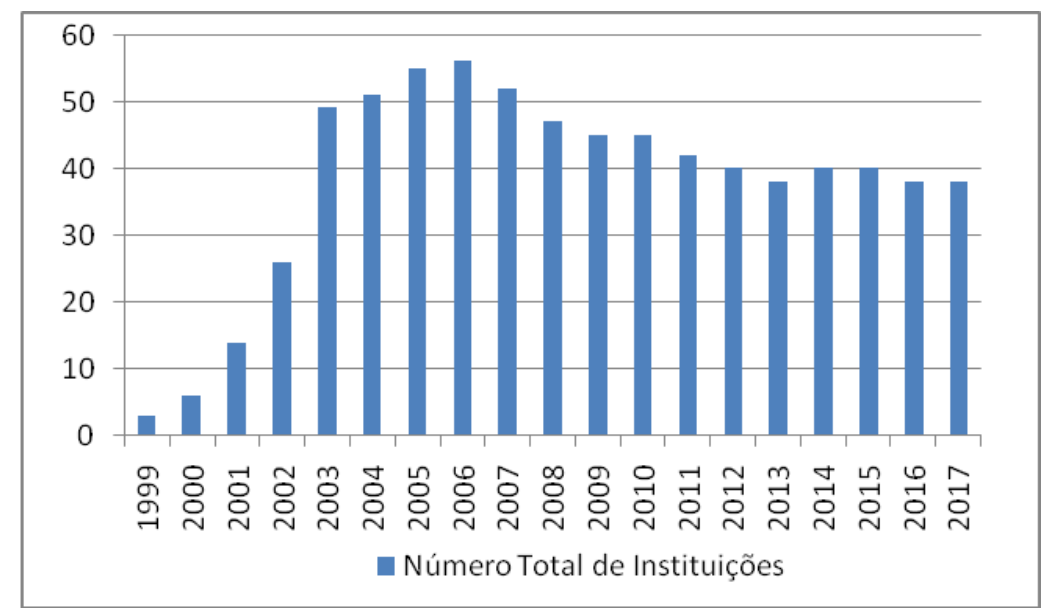

Figura 18. Evolução anual do número de SCMEPPs registradas no Banco Central do Brasil

Fonte: Elaboração própria a partir de BACEN. Atualização Mensal de Dados sobre Evolução do Sistema Financeiro. Disponível em: http://www.bcb.gov.br/?SFNATUALMES Acesso em: 21/11/2017.

Em contrapartida, a Figura 19 indica que o número de SCMEPPs atuando no âmbito do Programa Nacional de Microcrédito Produtivo Orientado tem crescido ao 
longo do tempo, passando de apenas dez instituições, no início do Programa em 2005, para dezenove no segundo semestre de 2009. Em 2011, o total registrado foi de vinte e cinco instituições, atingindo a marca de vinte e oito no segundo semestre de 2015.

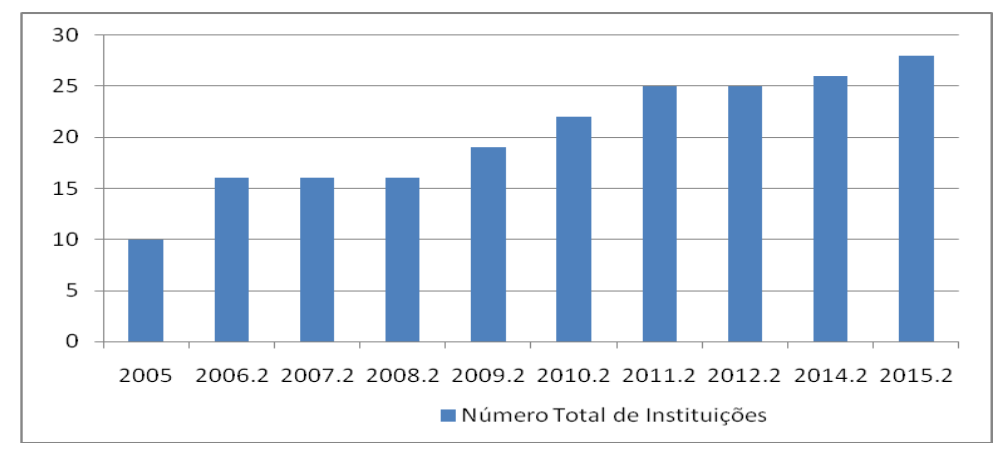

Figura 19. Evolução semestral do número de SCMEPPs atuando via PNMPO

Fonte: Elaboração própria a partir de BRASIL. Ministério do Trabalho e do Emprego. PNMPO informações gerenciais do Programa Nacional de Microcrédito Produtivo Orientado. Disponível em: http://portalfat.mte.gov.br/programas-e-acoes-2/programa-nacional-do-microcredito-produtivoorientado-pnmpo/sistema-de-informacoes-do-pnmpo/ Acesso: 11/11/2017.

A Figura 20 aponta para a ampliação do número de cooperativas de livre admissão de associados a partir de 2005. Partindo de uma única instituição atuante em áreas com até trezentos mil habitantes no ano de 2014, seu número praticamente dobrou entre 2005 e 2006, quando chegou a cento e uma instituições registradas. Com crescimento constante, o número de cooperativas de crédito de livre admissão chegou a duzentas e trinta e duas em 2010, totalizando trezentas e catorze no ano de 2015. Em 2017, o total reportado foi de trezentas e cinquenta instituições.

Embora as cooperativas de livre admissão atuantes em regiões com até trezentos mil habitantes tenham mantido seu predomínio ao longo de todo o período, aquelas operando em regiões com população entre trezentos mil e setecentos e cinquenta mil habitantes passaram a ganhar espaço a partir de 2010, quando totalizavam quarenta e três instituições, passando para setenta e três em 2015. As atuantes em regiões com população entre setecentos e cinquenta mil e dois milhões de habitantes evoluíram de vinte instituições registradas em 2010 para sessenta e oito em 2015. Finalmente, aquelas atuantes em regiões com população superior a dois milhões de habitantes passaram de um total de apenas duas em 2012 para dezoito em 2015. 


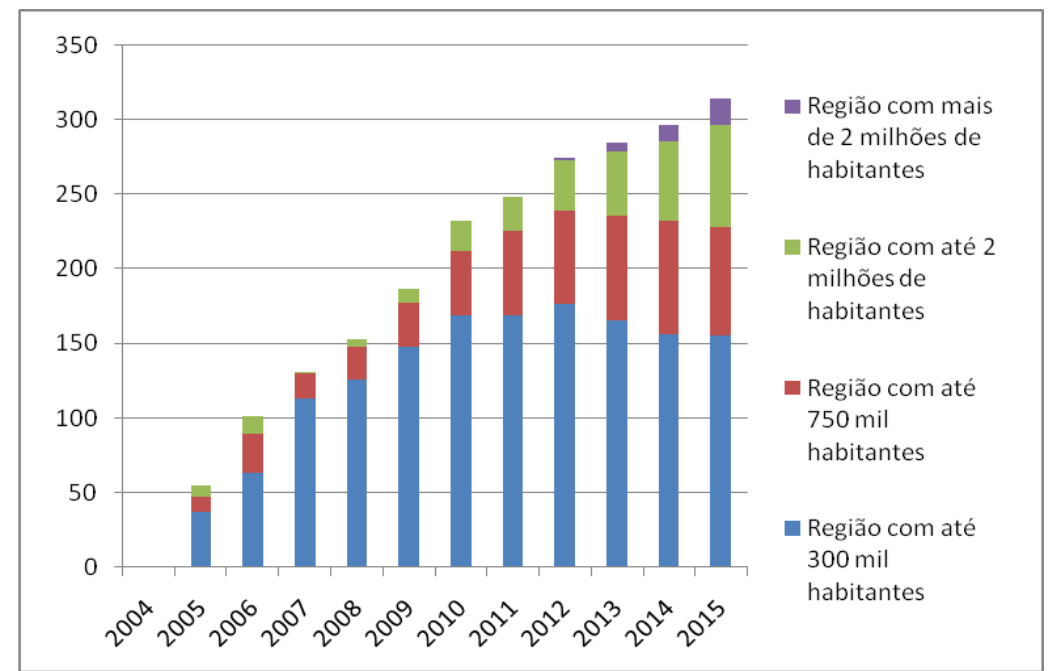

Figura 20. Evolução anual do número de cooperativas de livre admissão por limite populacional atendido

Fonte: Elaboração própria a partir de BACEN. Atualização Mensal de Dados sobre Evolução do Sistema Financeiro. Disponível em: http://www.bcb.gov.br/?SFNATUALMES Acesso em: 21/11/2017.

De acordo com a Figura 21, a atuação das cooperativas de crédito via Programa Nacional de Microcrédito Produtivo Orientado ganhou força a partir de 2014, quando foi atingido um total de duzentas e noventa e duas instituições frente as cento e sessenta e oito reportadas em 2011 e 2012. Tal aumento provavelmente se deveu também ao ano de 2013, embora não seja possível auferir com certeza dada a ausência de informações para esse ano.

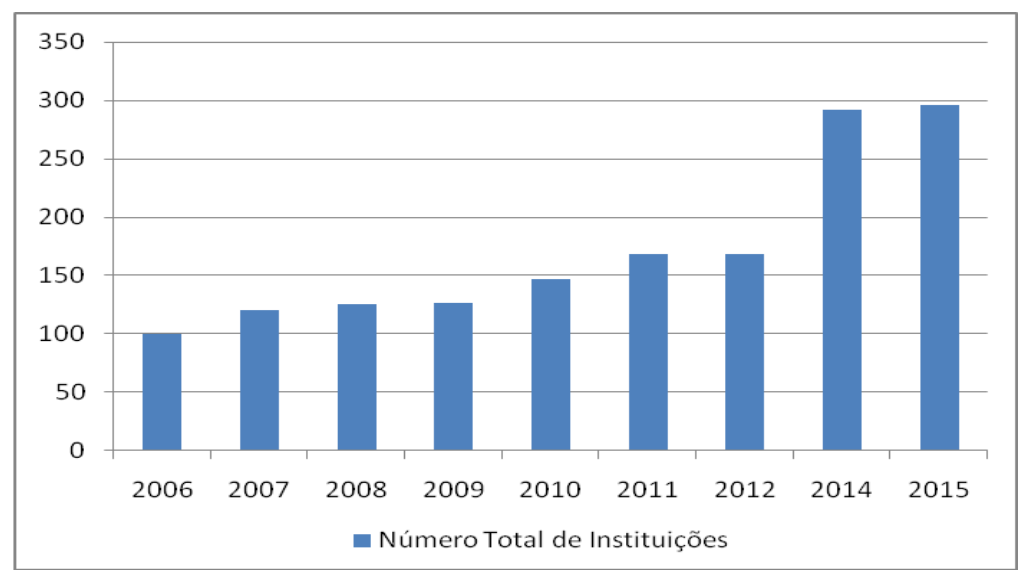

Figura 21. Evolução anual do número de cooperativas de crédito atuando no âmbito do PNMPO Fonte: Elaboração própria a partir de BRASIL. Ministério do Trabalho e do Emprego. PNMPO informações gerenciais do Programa Nacional de Microcrédito Produtivo Orientado. Disponível em: http://portalfat.mte.gov.br/programas-e-acoes-2/programa-nacional-do-microcredito-produtivoorientado-pnmpo/sistema-de-informacoes-do-pnmpo/ Acesso: 11/11/2017. 
Por fim, a Figura 22 indica que o Programa Nacional de Microcrédito Produtivo Orientado apresentou elevação significativa no quantitativo de instituições nele inseridas. Das cinquenta e duas instituições registradas em 2005, o número passou a ser de duzentas e dezesseis já no ano seguinte. Com crescimento constante, instituições participantes eram trezentas e quarenta e oito em 2011, atingindo seu ápice com quinhentas e vinte e três em 2015.

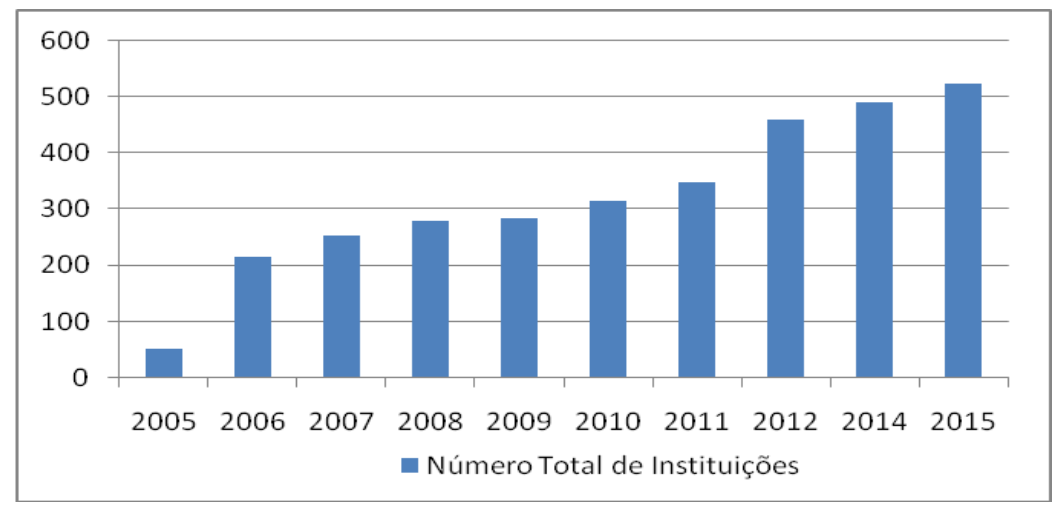

Figura 22. Evolução anual do número de instituições atuando no PNMPO

Fonte: Elaboração própria a partir de BRASIL. Ministério do Trabalho e do Emprego. PNMPO informações gerenciais do Programa Nacional de Microcrédito Produtivo Orientado. Disponível em: http://portalfat.mte.gov.br/programas-e-acoes-2/programa-nacional-do-microcredito-produtivo-

orientado-pnmpo/sistema-de-informacoes-do-pnmpo/ Acesso: 11/11/2017.

Em termos de estrutura do setor de microcrédito brasileiro, observa-se que o resultado esperado de ampliação do número de Organizações da Sociedade Civil de Interesse Público se concretizou. No caso das SCMEPPs, também foi encontrado o resultado esperado de quantidade limitada de instituições organizadas sob esse modelo institucional, uma possível consequência das exigências elevadas de patrimônio líquido ajustado. Dessa maneira, a reformulação do modelo no final de 2007 não parece ter funcionado para atrair instituições para o modelo.

No caso das cooperativas de crédito de livre admissão, foi encontrado o efeito esperado de ampliação do número de instituições, com predomínio daquelas de menor porte, atuantes em regiões com até trezentos mil habitantes. Logo, as exigências significativamente mais elevadas de capital de entrada e patrimônio líquido não apresentaram os efeitos esperados. Por outro lado, o crescimento no número de cooperativas de crédito atuando no âmbito do PNMPO, somado ao número 
relativamente baixo de clientes atendidos, conforme discutido abaixo, reforça a ideia de um grande número de cooperativas de crédito de pequeno porte.

No que diz respeito ao Programa Nacional de Microcrédito Produtivo Orientado, o crescimento observado no número de instituições participantes contradiz a expectativa de que a redução dos limites de juros impostos às instituições operando com recursos do Fundo de Amparo ao Trabalhador geraria uma queda na participação no PNMPO.

\subsubsection{Alcance}

Acerca das OSCIPs, a Figura 23 aponta para um crescimento constante do número de clientes entre o primeiro trimestre de 2012 e o segundo trimestre de 2013, interrompido apenas por queda significativa no quarto trimestre do ano de 2012. Nesse período, de cerca de cinquenta e nove mil clientes atendidos por OSCIPs, o total passou para aproximadamente setenta e um mil. Após uma brusca queda para trinta e oito mil no terceiro trimestre de 2013, o total nunca mais retornou aos patamares anteriores. No terceiro de trimestre de 2015, último registro da série, as OSCIPs atenderam somente dezoito mil clientes no âmbito do PNMPO.

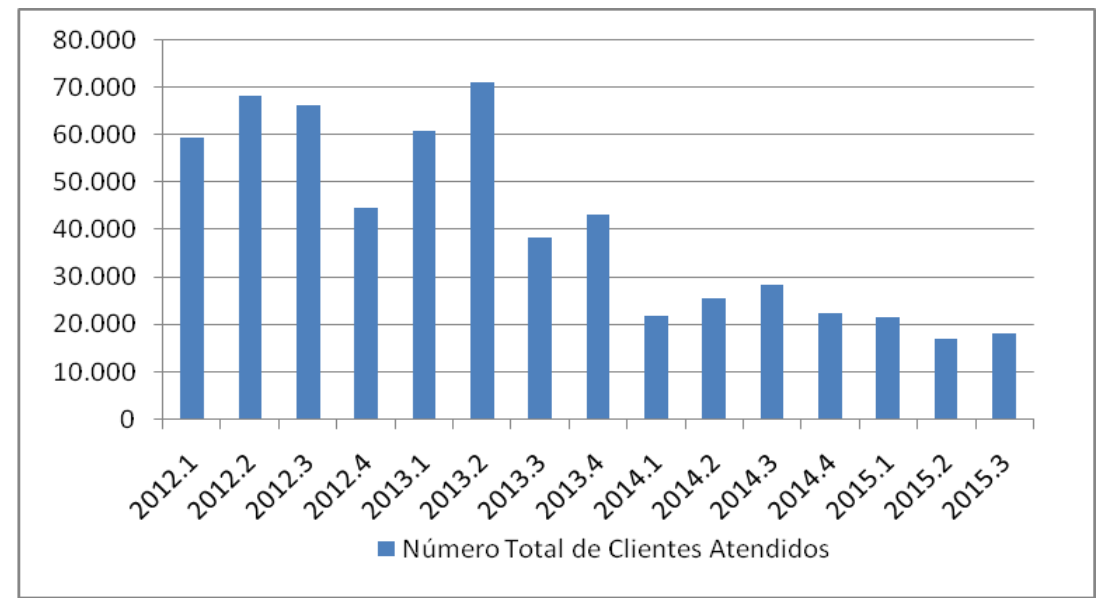

Figura 23. Evolução trimestral do número total de clientes atendidos por OSCIPs no âmbito do PNMPO

Fonte: Elaboração própria a partir de BRASIL. Ministério do Trabalho e do Emprego. PNMPO informações gerenciais do Programa Nacional de Microcrédito Produtivo Orientado. Disponível em: http://portalfat.mte.gov.br/programas-e-acoes-2/programa-nacional-do-microcredito-produtivoorientado-pnmpo/sistema-de-informacoes-do-pnmpo/ Acesso: 11/11/2017. 
A Figura 24 indica que o volume de recursos emprestados pelas OSCIPs no âmbito do PNMPO seguiu trajetória semelhante, passando de cento e sessenta e sete milhões de reais no primeiro trimestre de 2012 para cento e noventa e quatro milhões de reais no segundo trimestre de 2013, superando a queda brusca registrada no trimestre final de 2012. No terceiro trimestre de 2013, no entanto, o valor total apresentado caiu para cento e quinze milhões de reais, mantendo-se em declínio constante, tendo sido emprestados apenas sessenta e sete milhões no terceiro trimestre de 2015.

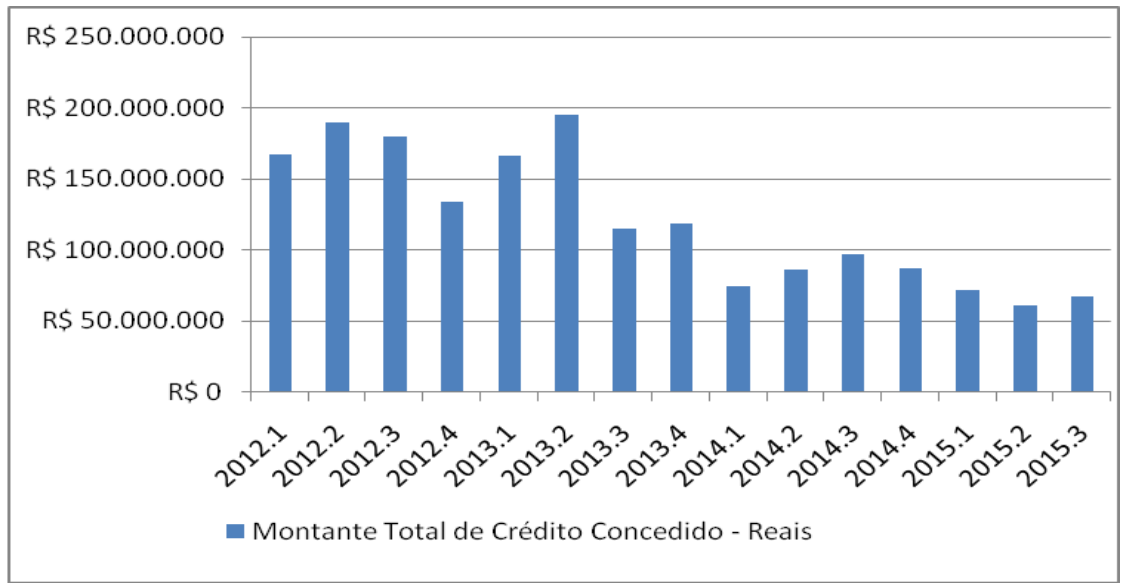

Figura 24. Evolução trimestral do montante de recursos emprestados por OSCIPs no âmbito do PNMPO

Fonte: Elaboração própria a partir de BRASIL. Ministério do Trabalho e do Emprego. PNMPO informações gerenciais do Programa Nacional de Microcrédito Produtivo Orientado. Disponível em: http://portalfat.mte.gov.br/programas-e-acoes-2/programa-nacional-do-microcredito-produtivo-orientadopnmpo/sistema-de-informacoes-do-pnmpo/ Acesso: 11/11/2017.

A Figura 25 mostra que o montante de clientes atendidos pelas SCMEPPs no âmbito do PNMPO partiu de apenas trezentos e sessenta e sete no terceiro trimestre de 2013 para catorze mil e seiscentos no primeiro trimestre de 2014, atingido total próximo a vinte e três mil no trimestre seguinte. Entretanto, o terceiro trimestre de 2014 registrou apenas quinhentos e oitenta e quatro clientes. O número voltou a subir para aproximadamente quinze mil no trimestre seguinte, mantendo aumento constante até atingir os cerca de vinte mil clientes no terceiro trimestre de 2015. Nesse sentido, os dados registrados no terceiro trimestre de 2013 e no terceiro trimestre de 2014 podem corresponder a problemas na coleta de informações junto às SCMEPPs. De qualquer modo, o total jamais superou a casa dos vinte e três mil, apresentando números bastante inferiores àqueles observados no caso das OSCIPs, por exemplo. 


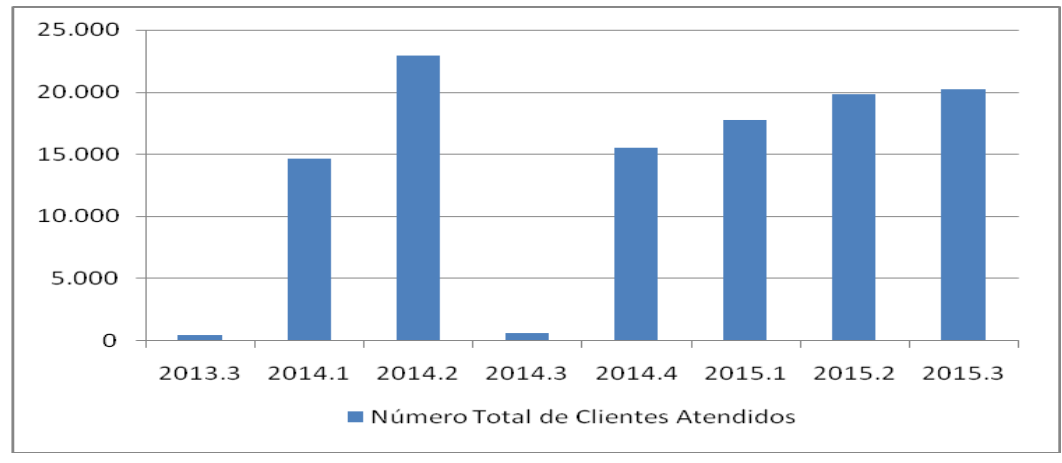

Figura 25. Evolução trimestral no número total de clientes atendidos por SCMEPPs

Fonte: BRASIL. Ministério do Trabalho e do Emprego. PNMPO - informações gerenciais do Programa Nacional de Microcrédito Produtivo Orientado. Disponível em: http://portalfat.mte.gov.br/programas-eacoes-2/programa-nacional-do-microcredito-produtivo-orientado-pnmpo/sistema-de-informacoes-dopnmpo/ Acesso: 11/11/2017.

Em termos de recursos emprestados pelas SCMEPPs via PNMPO, a Figura 26 indica padrão similar àquele observado para o número de clientes atendidos. Os baixos valores encontrados para o terceiro trimestre de 2013 e para o terceiro trimestre de 2014 podem, novamente, ser consequências de problemas na coleta dos dados. De toda forma, o montante emprestado atingiu seu ápice no segundo trimestre de 2014, com aproximadamente sessenta e oito milhões de reais. No quarto trimestre de 2014 foram concedidos quarenta e sete milhões de reais pelas Sociedades de Crédito ao Microempreendedor e Empresa de Pequeno Porte em operações de microcrédito produtivo orientado, valor que se estabilizou próximo aos cinquenta e três milhões de reais nos últimos três trimestres para os quais foram divulgados dados.

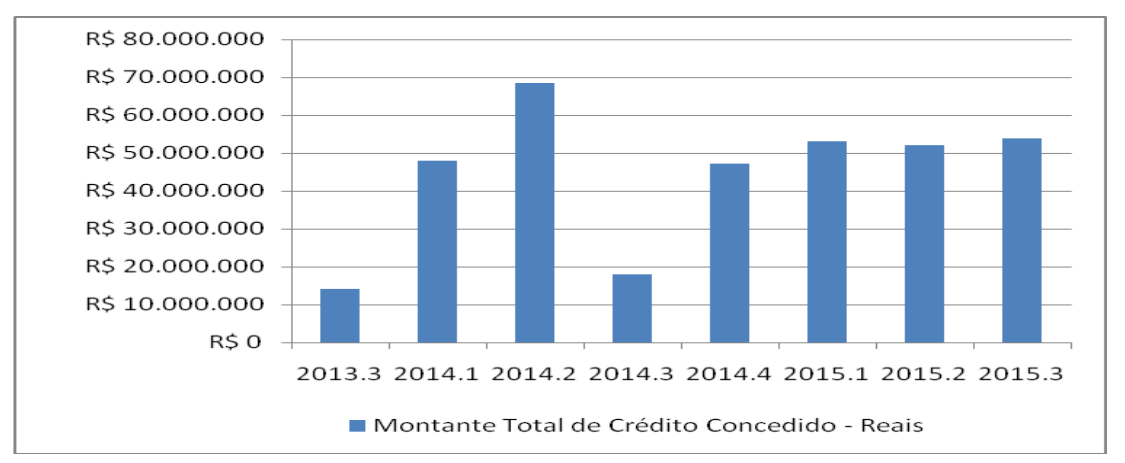

Figura 26. Evolução trimestral do montante de recursos emprestados por SCMEPPs no âmbito do PNMPO

Fonte: Elaboração própria a partir de BRASIL. Ministério do Trabalho e do Emprego. PNMPO informações gerenciais do Programa Nacional de Microcrédito Produtivo Orientado. Disponível em: 
http://portalfat.mte.gov.br/programas-e-acoes-2/programa-nacional-do-microcredito-produtivo-

orientado-pnmpo/sistema-de-informacoes-do-pnmpo/ Acesso: 11/11/2017.

Por sua vez, o número de clientes atendidos por cooperativas de crédito via PNMPO se manteve relativamente estável entre os anos de 2013 e de 2015, flutuando sempre entre os cinco mil e quinhentos clientes atendidos no terceiro trimestre de 2013 e os nove mil registrados no terceiro trimestre de 2015. Conforme observado na Figura 27, as variações mais significativas ocorreram entre o quarto trimestre de 2013 e o primeiro de 2014, quando houve redução de mais de mil clientes, e entre o segundo e o terceiro trimestre de 2015, com aumento próximo de mil e duzentos clientes atendidos.

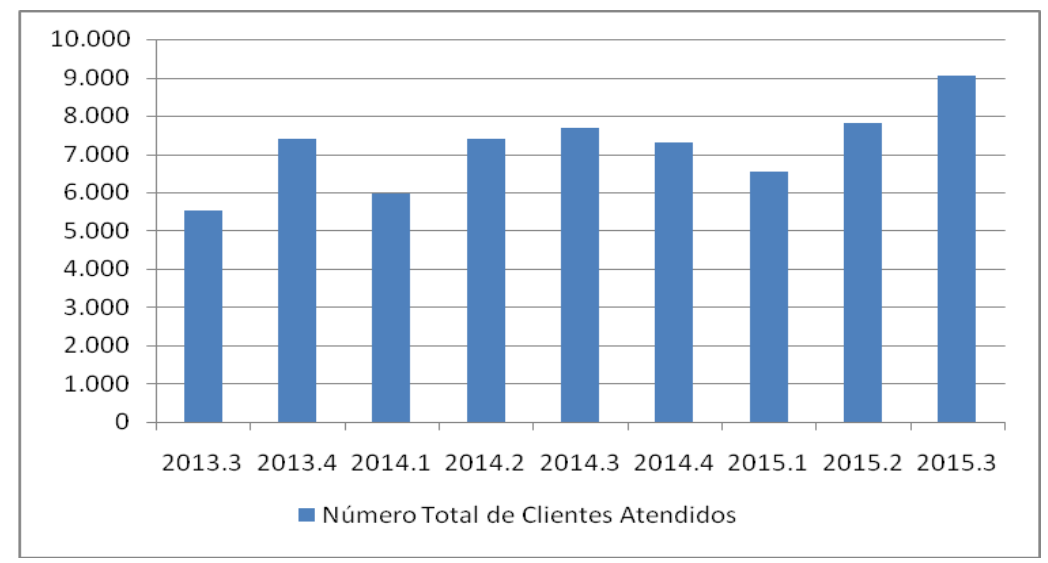

Figura 27. Evolução trimestral do número total de clientes atendidos por cooperativas de crédito no âmbito do PNMPO

Fonte: Elaboração própria a partir de BRASIL. Ministério do Trabalho e do Emprego. PNMPO informações gerenciais do Programa Nacional de Microcrédito Produtivo Orientado. Disponível em: http://portalfat.mte.gov.br/programas-e-acoes-2/programa-nacional-do-microcredito-produtivoorientado-pnmpo/sistema-de-informacoes-do-pnmpo/ Acesso: 11/11/2017.

A Figura 28 indica que os montantes de crédito concedidos por cooperativas no contexto do PNMPO mantiveram-se entre a faixa dos cinquenta milhões registrados no terceiro trimestre de 2013 e dos oitenta e quatro milhões de reais reportados no terceiro trimestre de 2015. Em termos de queda no total emprestado, a redução mais significativa ocorreu entre o fim de 2013 e o primeiro trimestre de 2014, passando de sessenta e cinco milhões de reais para cinquenta e quatro milhões de reais. No sentido oposto, entre o primeiro e o segundo trimestre de 2014, houve aumento de treze milhões de reais nos montantes registrados. Por fim, entre o primeiro e o segundo trimestre de 
2015, os valores contabilizados evoluíram de sessenta e dois milhões de reais para setenta e cinco milhões de reais.

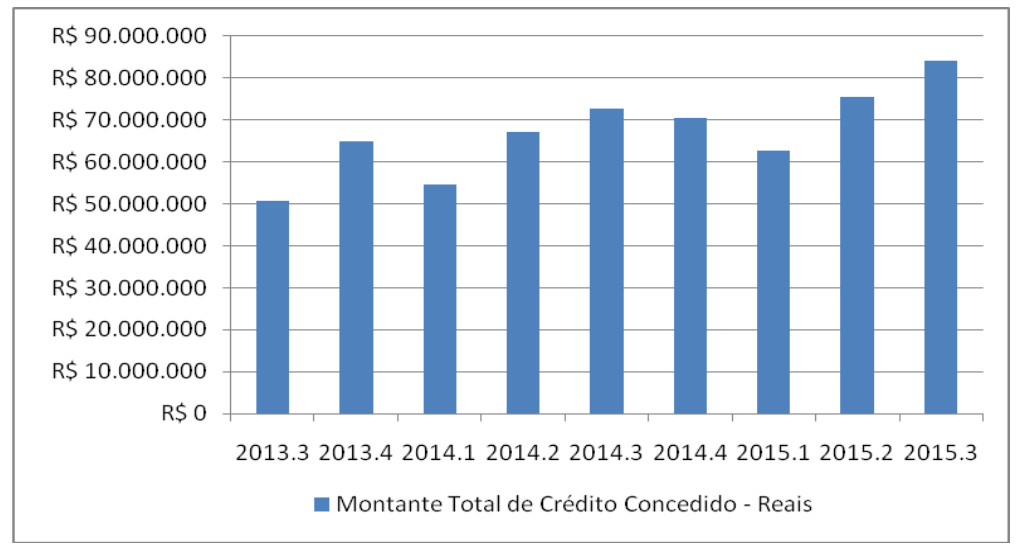

Figura 28. Evolução trimestral do montante de recursos emprestados por cooperativas de crédito no âmbito do PNMPO

Fonte: Elaboração própria a partir de BRASIL. Ministério do Trabalho e do Emprego. PNMPO informações gerenciais do Programa Nacional de Microcrédito Produtivo Orientado. Disponível em: http://portalfat.mte.gov.br/programas-e-acoes-2/programa-nacional-do-microcredito-produtivoorientado-pnmpo/sistema-de-informacoes-do-pnmpo/ Acesso: 11/11/2017.

Em termos da exigibilidade de direcionamento de recursos, a atuação das instituições a ela sujeitas apresenta poucos dados disponíveis. Uma alternativa, ainda que certamente imperfeita, dado que não abarca todas as instituições submetidas a essa regulação, gira em torno da apreciação do envolvimento de bancos públicos no setor de microcrédito. Olhando para as operações realizadas por essas instituições no âmbito do Programa Nacional de Microcrédito Produtivo Orientado, dispostas na Figura 29, verifica-se que a concessão de mirocrédito por essas instituições era significativa já no primeiro trimestre de 2012, quando foi ultrapassada a casa do um bilhão e cem mil reais concedidos. O ápice de recursos concedidos ocorreu no primeiro trimestre de 2014, com o montante total girando em torno de três bilhões e oitocentos milhões de reais, valor que decaiu subsequentemente, embora sempre próximo ou acima do patamar dos dois bilhões e quinhentos milhões de reais.

Ao longo de todo o período, o Banco do Nordeste do Brasil manteve-se como a instituição mais relevante em termos de recursos concedidos, o que certamente indica a influência de seu histórico operando no setor, em especial por intermédio do Crediamigo. Porém, a partir do quarto trimestre de 2012, a concessão de microcrédito 
produtivo orientado do Banco do Brasil e da Caixa Econômica Federal passou a crescer. É importante ressaltar que, além das exigências de direcionamento de depósitos à vista, o governo federal utilizou também o Programa Crescer, lançado em 2011 no âmbito do PNMPO, para estimular a atuação dos bancos públicos na concessão de microcrédito para microempreendedores.

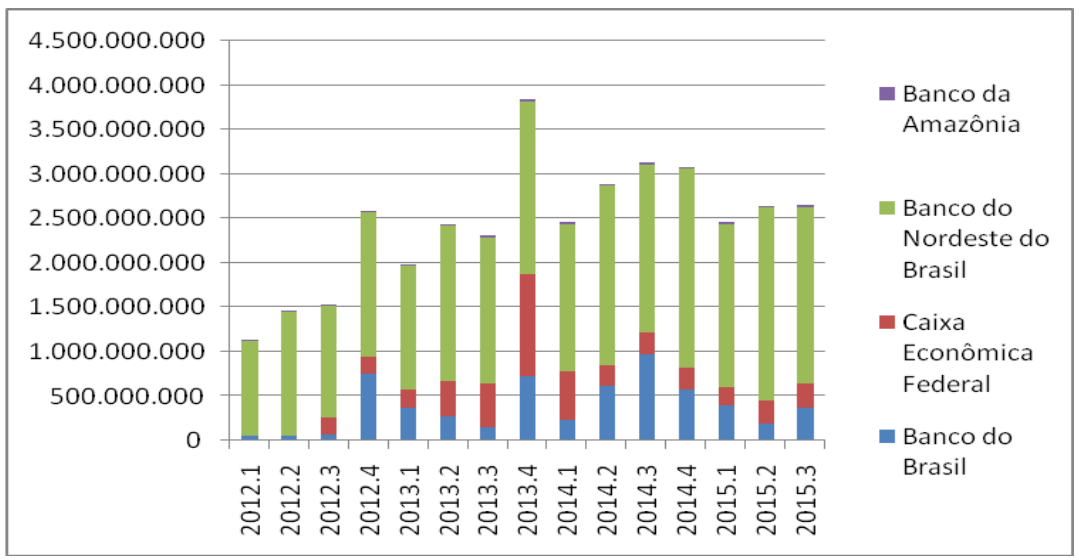

Figura 29. Evolução trimestral no montante total de crédito concedido por Bancos Públicos Federais no âmbito do PNMPO

Fonte: Elaboração própria a partir de BRASIL. Ministério do Trabalho e do Emprego. PNMPO informações gerenciais do Programa Nacional de Microcrédito Produtivo Orientado. Disponível em: http://portalfat.mte.gov.br/programas-e-acoes-2/programa-nacional-do-microcredito-produtivoorientado-pnmpo/sistema-de-informacoes-do-pnmpo/ Acesso: 11/11/2017.

A Figura 30 apresenta grande disparidade entre o total de clientes atendidos pelo Banco do Nordeste do Brasil e as demais instituições. Em três ocasiões, a instituição superou sozinha a marca de um milhão de clientes, enquanto os melhores desempenhos de Banco do Brasil e da Caixa Econômica Federal mantiveram-se abaixo dos quinhentos mil clientes. Após bons resultados no quarto trimestre de 2013, os dois bancos voltaram a perder espaço. 


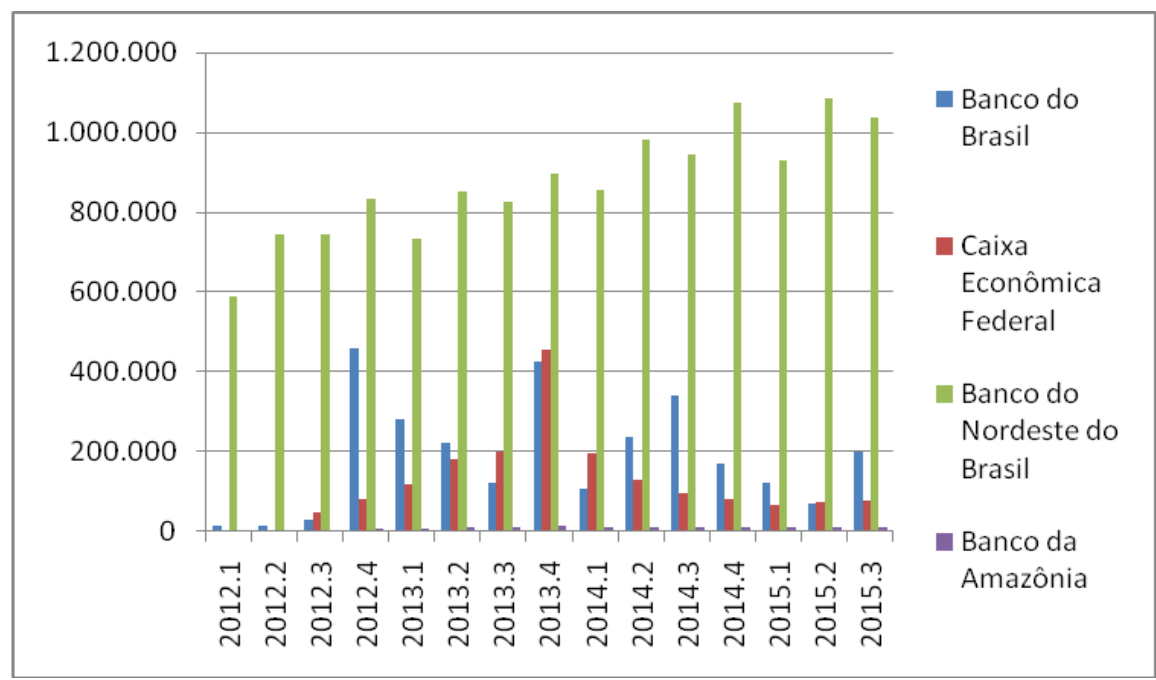

Figura 30. Evolução trimestral no número total de clientes atendidos por Bancos Públicos Federais no âmbito do PNMPO

Fonte: Elaboração própria a partir de BRASIL. Ministério do Trabalho e do Emprego. PNMPO informações gerenciais do Programa Nacional de Microcrédito Produtivo Orientado. Disponível em: http://portalfat.mte.gov.br/programas-e-acoes-2/programa-nacional-do-microcredito-produtivoorientado-pnmpo/sistema-de-informacoes-do-pnmpo/ Acesso: 11/11/2017.

Acerca do PNMPO, a Figura 31 aponta para a evolução no volume de microcrédito concedido a cada ano entre 2005 e 2014, quando passou de cerca de um bilhão de reais para doze bilhões e quatrocentos milhões de reais. Entre 2014 e 2015, no entanto, houve queda de quatro bilhões de reais nos valores reportados.

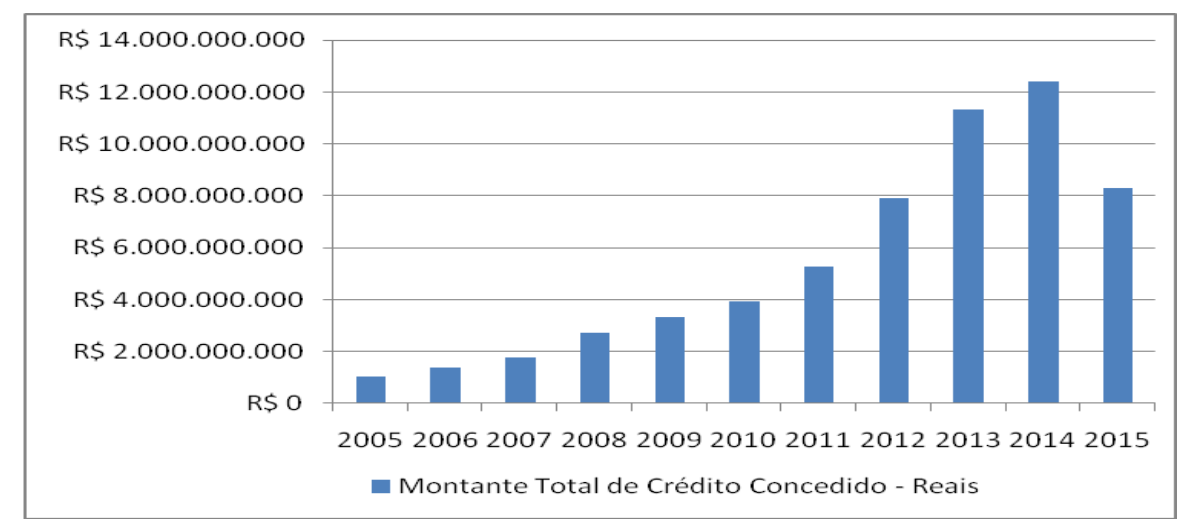

Figura 31. Evolução anual no montante total de crédito concedido no âmbito do PNMPO - Valores reais

Fonte: Elaboração própria a partir de BRASIL. Ministério do Trabalho e do Emprego. PNMPO informações gerenciais do Programa Nacional de Microcrédito Produtivo Orientado. Disponível em: http://portalfat.mte.gov.br/programas-e-acoes-2/programa-nacional-do-microcredito-produtivoorientado-pnmpo/sistema-de-informacoes-do-pnmpo/ Acesso: 11/11/2017. 
A respeito do valor médio das operações de microcrédito produtivo orientado no âmbito do PNMPO, a Figura 32 indica a flutuação em torno de dois mil reais entre 2008 e 2015, após início próximo aos mil e quinhentos reais no ano de 2005.

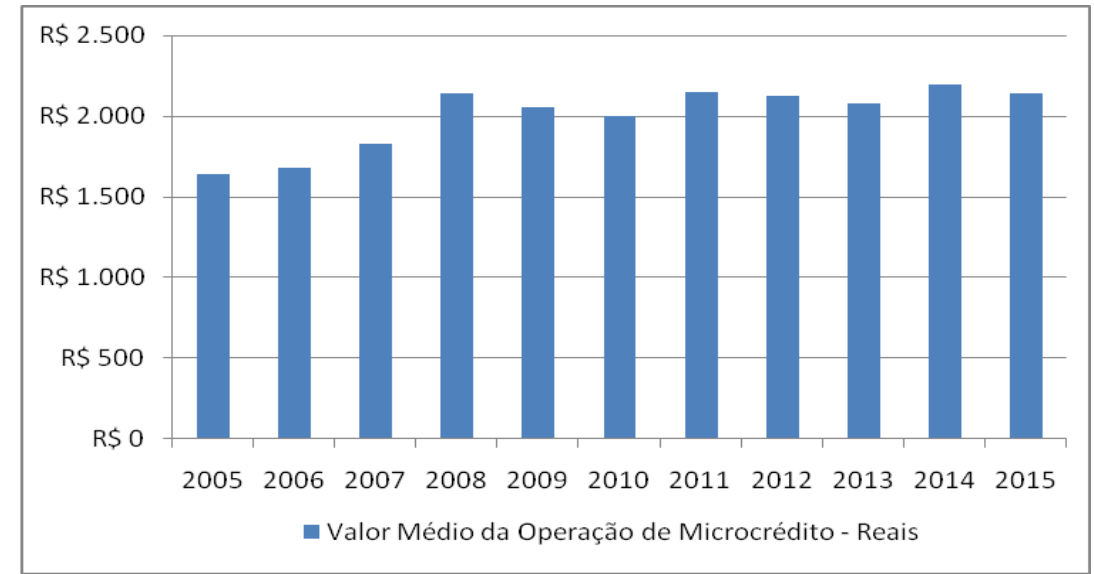

Figura 32. Evolução anual do valor médio das operações de crédito no âmbito do PNMPO Valores reais

Fonte: Elaboração própria a partir de BRASIL. Ministério do Trabalho e do Emprego. PNMPO informações gerenciais do Programa Nacional de Microcrédito Produtivo Orientado. Disponível em: http://portalfat.mte.gov.br/programas-e-acoes-2/programa-nacional-do-microcredito-produtivoorientado-pnmpo/sistema-de-informacoes-do-pnmpo/ Acesso: 11/11/2017.

Observamos, por conseguinte, que os resultados esperados de ampliação do alcance pelas Organizações da Sociedade Civil de Interesse Público não se confirmou, sendo que tanto o total de clientes quanto o montante de recursos emprestado sofreram quedas significativas a partir do segundo trimestre de 2013. O mesmo ocorreu no caso das SCMEPPs, com os resultados esperados de maior alcance em razão da possibilidade de atendimento de empresas de pequeno porte e da flexibilização dos limites de diversificação de risco por cliente não se concretizando. No âmbito do PNMPO, o número de clientes atendidos se manteve praticamente irrisório, sempre abaixo dos vinte e três mil.

Para as cooperativas de crédito, os resultados esperados de redução do alcance em decorrência da possibilidade de realização de operações de maior valor não foram observados. Tomando como base a atuação dessas instituições no âmbito do PNMPO, o número de clientes apresentou crescimento no período reportado, estando de acordo com a previsão decorrente da ampliação do limite de endividamento dessas instituições, 
embora seja relevante destacar que nunca superou a marca dos dez mil clientes, número consideravelmente baixo. No mesmo sentido, a evolução do montante de recursos concedidos pelas cooperativas de crédito no âmbito do Programa evoluiu proporcionalmente, sugerindo que não houve a busca por realizar operações de maior valor e que, portanto, as previsões de melhora na autossustentabilidade financeira também não teriam se concretizado.

Em termos da exigibilidade de direcionamento de recursos, no caso da atuação dos bancos públicos via PNMPO, tanto os montantes despendidos quanto o número de clientes atendidos apresentaram variação positiva ao longo do tempo. Nesse contexto, a previsão de maior envolvimento se comprovaria, embora a previsão de redução na do alcance não tenha se verificado.

Por fim, os resultados previstos a respeito do PNMPO não se comprovaram. O valor médio das operações de microcrédito no âmbito do Programa manteve-se relativamente estável e em um patamar mediano próximo dos dois mil reais, o que contradiz as expectativas de migração para um número menor de clientes de menor renda.

\section{Estudo de Caso - México}

O Sistema Financeiro mexicano é configurado pelos setores bancário, bursátil, de derivativos, de seguros e garantias e de previdência e pelo sector de ahorro y crédito popular (ZARATE, 2010: p.46), embora este último tenha sido por muito tempo considerado como residual ao Sistema Financeiro Formal (GÓMEZ, 2013: p.92). Sua regulação é realizada direta ou indiretamente pela Secretaría de Hacienda y Crédito Público (SHCP) por intermédio de suas comissões, dentre as quais se destacam o Banco de México (Banxico) e a Comisión Nacional Bancaria de Valores (CNBV) (PEREZSOTO, 2016: p.145).

São parte do sector de ahorro y crédito popular as sociedades cooperativas de ahorro y préstamo (SOCAPs) e as sociedades financieras populares (SOFIPOs), ambas constituídas pela Ley de Ahorro y Crédito Popular (LACP), de 2001 (PEREZ-SOTO, 2016: p.145), que buscou consolidar nesses dois modelos o grande número de cajas populares, cajas solidarias, cooperativas de ahorro y préstamo (CAPs) e sociedades de ahorro y préstamo (SAPs). Ademais, o setor engloba também as sociedades financieras 
comunitarias (SOFINCOs), constituídas a partir de 2009 com a reforma da LACP (PEREZ-SOTO, 2016: pp.148-149).

Sua relevância reside no fato de as instituições dele integrantes concederem serviços a parcelas da população não atendidas por bancos tradicionais ou por outras instituições financeiras. Dessa maneira, conseguem atingir regiões de difícil acesso e com possibilidades reduzidas de desenvolvimento, algo essencial para a ampliação do acesso a serviços financeiros pela população mexicana (GÓMEZ, 2013: p.92).

Além das SOCAPs, SOFIPOs e SOFINCOs, podem desempenhar atividades de microcrédito quaisquer instituições adequadas ao marco legal. Dentre elas, encontramse ONGs, sociedades anônimas, uniones de crédito, bancos e sociedades de objeto múltiple (SOFOMEs), além das antigas sociedades de objeto limitado (SOFOLEs), extintas desde julho de 2013 (MARULANDA CONSULTORES, 2011: p.11).

\subsection{Histórico}

As primeiras cajas populares mexicanas se estabeleceram em 1951, por iniciativa da Igreja Católica. Essas instituições se agruparam em federações que, a partir de 1964, passaram a fazer parte da Confederación Mexicana de Cajas Populares. Sua atuação se deu, por décadas, sem qualquer forma de regulação governamental (PEREZSOTO, 2016: pp.146-147).

Em setembro de 1982, no contexto de moratória da dívida externa do país, o presidente mexicano José Portillo concretizou a nacionalização dos bancos privados (GUERRA, 2015: p. 1324). Nesse quadro, dadas as desconfianças da população em relação aos novos bancos governamentais, instituições não bancárias, dentre as quais as cajas populares, tiveram seu desenvolvimento favorecido, estando entre as poucas alternativas de acesso a serviços como crédito e poupança para a população ((RHYNE et al, 2004: p.19).

Visando uma maior regulação, a reforma da Ley General de Organizaciones y Actividades Auxiliares de Crédito (LGOAAC), levada a cabo em dezembro de 1991, constituiu a figura das sociedades de ahorro y préstamo (SAPs), figura jurídica considerada organização auxiliar de crédito e pela qual optaram muitas cajas populares como forma de obter reconhecimento legal. No mesmo sentido, em agosto de 1994, a

reforma da Ley General de Sociedades Cooperativas (LGSC) promoveu o reconhecimento legal da atuação das cooperativas de ahorro y préstamo como passíveis 
de desempenhar atividades de poupança, empréstimos e, de forma complementar, de consumo. Com o estabelecimento de requisitos mais flexíveis para a autorização e atuação das cooperativas de ahorro y préstamo na comparação com as SAPs (MUCIÑO, 2015: p.55), muitas das cajas populares optaram por adotar a forma de cooperativas (PEREZ-SOTO, 2016: p.148).

Ainda no início da década de 1990, sob a administração de Carlos Salinas e em um contexto de reformas liberalizantes, foi levada a cabo a reprivatização do setor bancário (GUERRA, 2015: p. 1324), resultando em grande concentração da propriedade bancária, especialmente em mãos estrangeiras. No entanto, foram mantidas a forte atuação dos bancos de desenvolvimento e a oferta de financiamentos a taxas de juros subsidiadas para microempresas, de certo modo retardando o desenvolvimento das microfinanças no país (COTLER, 2011: p.5).

Com a crise de 1994, houve um processo de escassez do crédito disponível ao público (MARULANDA CONSULTORES, 2011: p.9). Dado que o governo federal se viu obrigado a intervir no sistema financeiro com o intuito de evitar seu colapso, as alternativas de acesso a crédito e a outros serviços financeiros se mostraram escassas. Nesse novo contexto, o governo mexicano buscou reduzir a atuação direta dos bancos de desenvolvimento estatais na concessão de crédito, transformando parte significativa de sua atuação no financiamento a instituições que realizam operações de crédito com os clientes finais (COTLER, 2011: p.14). Diante desse quadro adverso, muitas instituições conseguiram ganhar espaço no mercado. As primeiras iniciativas de microcrédito datam justamente desse período, sendo o setor de microfinanças mexicano um dos mais novos da América Latina (MIRANDA, 2015: p.21). No entanto, tendo em vista o fácil acesso a fundos públicos concedidos a taxas subsidiadas, havia poucos incentivos para a atração da poupança privada. Ao não captarem depósitos, instituições conseguiam atuar praticamente sem qualquer regulação governamental (COTLER, 2011: p.15).

No início dos anos 2000, sob o governo de Vicente Fox, passou-se a buscar a institucionalização dos atores envolvidos na concessão de serviços de finanças populares, o chamado sector de ahorro y crédito popular no qual se incluíam cajas populares, cooperativas de ahorro y préstamo, SAPs, cajas solidárias, entre outras instituições (PEREZ-SOTO, 2016: pp.148-149). Tratava-se também de uma tentativa de mitigar o problema da grande heterogeneidade de instituições atuando na área, muitas 
das quais oferecendo serviços financeiros exclusivos de instituições bancárias sem qualquer tipo de autorização governamental. A constituição do Banco del Ahorro Nacional y Servicios Financieros (BANSEFI), constituído a partir do antigo Patronato del Ahorro Nacional esteve entre as primeiras medidas, sendo a instituição responsável por coordenar tais esforços no contexto do Plano Nacional de Desarrollo para o período de 2001 a 2006. (GÓMEZ, 2013: p.94).

Nesse contexto, recursos obtidos do Banco Mundial e do Banco Interamericano de Desenvolvimento foram canalizados para o BANSEFI e redirecionados para projetos de assistência técnica, capacitação, desenvolvimento tecnológico, difusão do marco regulatório e fortalecimento das capacidades de monitoramento e de supervisão. Para além, foi constituída a Red de la Gente, aliança envolvendo diversas instituições do sector de ahorro y crédito popular e voltada para o oferecimento e promoção de serviços financeiros, além da distribuição de recursos do governo para diferentes regiões do país (GÓMEZ, 2013: pp.95-96).

Dentre as motivações para o processo de institucionalização estava a grave crise enfrentada pelas cajas de ahorro, organizadas sob os modelos de cooperativas de ahorro y préstamo e de sociedades de ahorro y préstamo (SAPs), constituídos na década anterior. Elas se viram afetadas por graves problemas de solvência e liquidez, bem como alguns casos de fraudes contra clientes que tiveram forte impacto sobre a confiança da população nessas instituições. Como forma de enfrentar a situação, que ameaçava se disseminar pelo conjunto do setor, a ley FIPAGO, de setembro de 2000, constituiu Fideicomiso para administrar o Fondo para el Fortalecimiento de Sociedades y Cooperativas de Ahorro y Préstamo y de Apoyo a sus Ahorradores. Dentre suas disposições, previu a cobertura de até $70 \%$ do saldo líquido de cada poupador, desde que abaixo de cento e noventa mil pesos (HERRERA, 2012: p.68).

No mesmo sentido, em junho de 2001, foi publicada a Ley de Ahorro y Crédito Popular (LACP), parte essencial da estratégia de concentração do grande número de modelos institucionais nas figuras das sociedades cooperativas de ahorro y préstamo (SOCAPs) e das sociedades financieras populares (SOFIPOs). Ambos os modelos precisariam de autorização da Comisión Nacional Bancaria de Valores (CNBV) para seu funcionamento, o que facilitaria o controle institucional. Porém, como forma de mitigar os custos de tal tarefa e superar a inexperiência com esse tipo de regulação (COTLER, 2011: p.15), a lei estabeleceu que estas seriam organizações base, inseridas 
em uma estrutura que contaria ainda com um segundo nível, constituído por estruturas federativas responsáveis por exercer supervisão auxiliar, e com um terceiro nível, composto por confederações que se dedicariam à administração de fundos de proteção (GÓMEZ, 2013: pp.94-95).

A LACP estabeleceu período transitório para que a miríade de instituições atuantes no sector de ahorro y crédito popular concretizassem seu processo de adequação. Ao fazê-lo, considerou a lentidão dos processos de obtenção de certificação fornecida por federações e de autorização para funcionamento concedida pela CNBV, trâmites exigidos para a constituição de SOCAPs, instituições sem fins lucrativos e integrantes do setor social da economia, e de SOFIPOs, sociedades anônimas com fins lucrativos e parte do setor privado (PEREZ-SOTO, 2016: p.153).

Contudo, boa parte do setor interpretou a nova lei como repleta de problemas, iniciando um longo processo de resistência à regulação e resultando em uma profunda divisão entre suas instituições (HERRERA, 2012: pp.68-69). Alegava-se que a LACP fora incapaz de considerar a filosofia cooperativa pela qual se pautava a atuação de grande parte das instituições que pretendia englobar, impondo regulações semelhantes a modelos institucionais com natureza jurídica e objetivos distintos (HERRERA, 2012: p.73).

Em decorrência da oposição imposta por parte do setor em se adequar à legislação, foram levadas a cabo oito reformas prevendo prorrogações de prazo para a entrada em vigor da Ley de Ahorro y Crédito Popular (LACP), entre outras disposições. Atendendo parcialmente as demandas do setor, a reforma de abril de 2007 reconheceu a existência de entidades não dedicadas a atividades financeiras, incluindo o compromisso de criar legislação específica que regesse o funcionamento dessas instituições (HERRERA, 2012: p.73). Dessa forma, a resistência iniciada ainda em 2001 resultou, em agosto de 2009, na promulgação da Ley para Regular las Actividades de las Sociedades Cooperativas de Ahorro y Préstamo (LRASCAP), que passou a regular a figura das SOCAPs. No mesmo sentido, foi realizada reforma na LACP, que deixou de abarcar as SOCAPs, mas manteve a regulação sobre as SOFIPOs e agregou sob sua égide a figura das recém constituídas sociedades financieras comunitarias (SOFINCOs) (GÓMEZ, 2013: p.97-98).

A partir das disposições da LRASCAP foi formalmente constituída, em abril de 2010, a Confederación de Cooperativas de Ahorro y Préstamo do México 
(CONCAMEX). Tratava-se de uma iniciativa voltada para reunificar a maioria dos grupos organizados e federações de cooperativas de ahorro y préstamo e de SOCAPs então existentes, garantindo relativa aceitação das disposições do novo marco jurídico (HERRERA, 2012: p.69). Já com a reforma da LACP, ocorreram alterações também no âmbito das estruturas das federações e do Comité de Supervisión Auxiliar. Antes dependente operacionalmente da CNBV e financeiramente das federações, passou a ser totalmente submetido à Comisión (GÓMEZ, 2013: p.98).

A LRASCAP constituiu um avanço relevante em termos de reconhecimento das SOCAPs como parte do setor social da economia, sem fins lucrativos e com atuação dissociada da intermediação financeira. No entanto, a lei apresenta uma séria contradição interna no sentido de que impõe mecanismos de regulação e supervisão que não condizem com esse reconhecimento. Foram mantidas diversas disposições já existentes na LACP, como a exigência de autorização de funcionamento pelo CNBV e a definição das operações que podem ser realizadas a partir do volume de ativos da instituição (HERRERA, 2012: pp.75-76).

Em janeiro de 2014, a Secretaría de Hacienda y Crédito Público (SHCP) publicou diferentes decretos reformando, adicionando e revogando diversas disposições em matéria financeira. A chamada Reforma Financeira, entre outras medidas, fortaleceu a Comisión Nacional para la Protección y Defensa de los Usuarios de Servicios Financieros (CONDUSEF) no intuito de reorientar seu objetivo como voltado em primeiro lugar para a proteção dos usuários de serviços financeiros, com capacidades para buscar equilíbrio na relação destes com entidades financeiras (DUEÑAS, 2017: p.114).

Em novembro do mesmo ano, foi deflagrada a fraude cometida pela sociedade financiera popular FICREA, com efeitos sobre mais de seis mil poupadores. Desse modo, teve início a elaboração de nova reforma à Ley de Ahorro y Crédito Popular, a décima primeira desde 2001, com o intuito de evitar problemas semelhantes. Denominada Ley FICREA, ela teria como intuito fortalecer o papel da Comisión Nacional Bancaria de Valores para intervir em SOFIPOs e supervisionar de forma direta essas entidades, papel até então desempenhado por suas próprias federações sob a forma de supervisão auxiliar. Ademais, ela estabeleceria limites para os níveis de crédito concedidos para clientes, tendo proposto também a eliminação da figura das SOFINCOs, criadas em 2009, com prazo para solicitar autorização de funcionamento 
como SOFIPOs (GUERRA, 2015: p.1322). Entretanto, diante de forte resistência do setor, a Ley FICREA não avançou no legislativo mexicano, não existindo perspectivas para sua aprovação.

\subsection{Modelos Institucionais}

Conforme discutido previamente, SOFIPOs, SOCAPs e SOFINCOs, consideradas parte do sector de ahorro y crédito popular, são alguns dos principais modelos institucionais envolvidos no setor mexicano de microfinanças. Como tal, estão sujeitas a autorização, regulação e supervisão por parte da Comisión Nacional Bancaria $y$ de Valores (CNBV) e à autossupervisão de suas próprias federações. Essas instituições são classificadas por níveis operacionais de acordo com seu volume de ativos, sendo definidas assim as atividades que estão autorizadas a desempenhar, incluindo a captação de depósitos do público (PEREZ-SOTO, 2016: p.153).

A despeito de estarem fora do sector de ahorro y crédito popular, sociedades financieras de objeto multiple (SOFOMEs), uniones de crédito e as extintas sociedades financieras de objeto limitado (SOFOLEs) também atuam ou atuaram no setor de microfinanças ao longo dos últimos anos.

As sociedades financieras de objeto multiple, obrigatoriamente registradas na Comisión Nacional para la Protección y Defensa de los Usuarios de Servicios Financieros (CONDUSEF), podem ser reguladas pela CNBV ou não, de acordo com seus vínculos patrimoniais e forma de financiamento. Dedicam-se a atividades de concessão de crédito, sendo-lhes vedada a captação de depósitos ${ }^{18}$. Por sua vez, as SOFOLEs eram instituições não bancárias com fins lucrativos, que se dedicavam à concessão de crédito para um tipo específico de atividade ou setor. Não podiam receber depósitos do público, obtendo recursos de bancos comerciais, de bancos de desenvolvimento, via emissão de títulos no mercado de ações ou empregando capital próprio. Finalmente, as uniones de crédito, classificadas de acordo com seus níveis de capital, dedicam-se a atividades de concessão de crédito e de financiamentos. Incluindo a captação de depósitos, todos os serviços por elas oferecidos são restritos a seus sócios.

18 SOFOMEs. Comisión Nacional Bancaria y de Valores. Em: http://www.cnbv.gob.mx/SECTORESSUPERVISADOS/OTROS-SUPERVISADOS/Descripci\%C3\%B3n-del-Sector/Paginas/SOFOMESReguladas.aspx Acesso: 10/07/2016. 
ONGs também atuam no setor de microfinanças, sem qualquer tipo de regulação. Entretanto, elas podem se transformar em qualquer um dos modelos acima abordados como forma de se tornarem instituições reguladas. Nesse sentido, o Banco Compartamos, líder do setor de microfinanças do México e da América Latina, iniciou suas operações como uma organização não governamental nos primeiros anos da década de 1990 (CERVANTES, 2014: p.14), transformando-se anos depois em SOFOL e, posteriormente, em banco múltiplo (ROSENBERG, 2007: pp.2-3) com uma das maiores carteiras de microcrédito do México (COTLER, 2011: p.17).

Portanto, bancos múltiplos também atuam no setor mexicano de microfinanças. A eles se somam os chamados bancos de nicho, modelo desenvolvido a partir de $2008 \mathrm{e}$ que conta com exigências de capital que variam de acordo com o tipo de atividade desempenhada (MARULANDA CONSULTORES, 2011: p.30).

Além de instituições do primeiro piso, que concedem serviços diretamente aos clientes, existem as instituições de segundo piso, fundos e instituições governamentais encarregados de distribuir recursos para as instituições que atuam diretamente com o cliente final (MARULANDA CONSULTORES, 2011: p.23). Dentre eles, destacam-se o Fideicomiso del Fondo de Microfinanciamiento a Mujeres Rurales (FONMUR), com foco em mulheres de baixa renda, e o Fideicomiso del Programa Nacional de Financiamiento al Microempresario (FINAFIM), ambos inseridos no Programa Nacional de Financiamiento al Microempresario (PRONAFIM) da Secretaría de Economía (MARTINEZ, 2008: pp.180-181).

No mesmo sentido, a Nacional Financiera (NAFIN) atua na ampliação do acesso a produtos de crédito para pequenas e médias empresas, enquanto o Banco Nacional de Servicios Financieros (BANSEFI) busca o desenvolvimento do sector de ahorro y crédito popular, de modo a ampliar o acesso a tais serviços pela população de baixa renda. O BANSEFI possui atuação tanto no primeiro quanto no segundo piso (ZARATE, 2010: pp.48-50). Conforme apontado por HERRERA (2012, p.79), trata-se de uma contradição que leva o Banco a competir com as próprias instituições que deve apoiar.

Nos últimos anos, novos atores como o Banco Walmart, Banco Azteca e Banco Coppel têm buscado adentrar o mercado de baixa e média renda (GINÉ, 2014: pp.5-6). Com atuação focada na concessão de crédito para consumo de pequena escala, têm conseguido concorrer com as instituições que atuam no setor de microcrédito por 
intermédio de condições mais flexíveis, gerando riscos de endividamento elevado de seus clientes (HERNANDEZ, 2014: p.9).

\subsubsection{SOFIPOs}

Sociedades financieras populares (SOFIPOs) são entidades de microfinanças constituídas como sociedades anônimas de capital variável, com fins lucrativos operando mediante autorização da CNBV e certificação obtida de uma federação. Tendo seu capital integrado com o aporte de acionistas, essas instituições podem prestar serviços financeiros tanto a seus acionistas quanto a seus clientes. Dentre as atividades desempenhadas estão a concessão de crédito, captação de depósitos, emissão e operação de cartões de débito, transferências, concessão de seguros e distribuição de recursos de programas governamentais, em geral destinadas a indivíduos de baixa renda (GUERRA, 2015: pp.1330-1331).

A gama de serviços que podem ser oferecidos por SOFIPOs está diretamente relacionada a seu volume de ativos, resultando na classificação dessas instituições por níveis.

O primeiro nível abarca as instituições com até quinze milhões de unidades de inversión (UDIS) ${ }^{19}$. O segundo e o terceiro níveis envolvem, respectivamente, as faixas entre quinze milhões e cinquenta milhões de UDIS e entre cinquenta milhões e duzentos e oitenta milhões de UDIS, enquanto o último nível inclui as SOFIPOs com volume de ativos superior a duzentos e oitenta milhões de UDIS (ZARATE, 2010: p.47). A Figura 33 apresenta as atividades que podem ser desempenhadas de acordo com o nível de classificação da SOFIPO. Nesse sentido, instituições de nível II podem realizar todas as operações que são facultadas para aquelas de nível I, além das que lhe são específicas. O mesmo vale para o nível III em relação às de nível I e II e para as de nível IV em relação a todas as demais.

\begin{tabular}{|c|c|c|}
\hline & Volume de Ativos (UDIS) & Atividades \\
\hline Nível I & Até 15.000 .000 & Concessão de crédito, captação \\
\hline
\end{tabular}

${ }^{19}$ Unidades de inversión são unidades de valor criadas no ano de 1995 como uma das respostas à crise bancária que assolava o México. Seu valor é atualizado diariamente, sendo reajustado de acordo com a inflação. 


\begin{tabular}{|c|c|c|}
\hline & & $\begin{array}{l}\text { de depósitos, emissão e operação } \\
\text { de cartões de débito, } \\
\text { transferências, concessão de } \\
\text { seguros, distribuição de recursos } \\
\text { de programas governamentais, } \\
\text { concessão de garantias, } \\
\text { recebimento de doações, entre } \\
\text { outros }\end{array}$ \\
\hline Nível II & $15.000 .000-50.000 .000$ & $\begin{array}{c}\text { Contratos de factoring, serviços } \\
\text { de seguros }\end{array}$ \\
\hline Nível III & $50.000 .000-280.000 .000$ & $\begin{array}{l}\text { Contratos de arrendamento, } \\
\text { serviços de caixa e tesouraria }\end{array}$ \\
\hline Nível IV & Acima de 280.000 .000 & $\begin{array}{l}\text { Emitir títulos de crédito para o } \\
\text { público investidor, expedir } \\
\text { cartões de crédito mediante } \\
\text { abertura de conta corrente de } \\
\text { seus clientes, realizar } \\
\text { investimentos em ações ou } \\
\text { Fundos de Aposentadoria }\end{array}$ \\
\hline
\end{tabular}

Figura 33. SOFIPOs - Volume de ativos e atividades permitidas por nível operacional

Fonte: SHCP. Disposiciones de Carácter General Aplicables a las Entidades de Ahorro y Crédito Popular, Organismos de Integración, Sociedades Financieras Comunitarias y Organismos de Integración Financiera Rural, a que se Refiere la Ley de Ahorro y Crédito Popular. D.O.F. 18/12/2006.

As sociedades financieras populares são sujeitas à supervisão da CNBV, que pode ocorrer de forma direta ou de maneira auxiliar pelas federações em que se agrupam voluntariamente essas sociedades. As SOFIPOs que optam pela não filiação têm uma federação indicada pela CNBV para emitir sua certificação e realizar sua supervisão auxiliar. Por sua vez, as federações são instituições de interesse público, com personalidade jurídica e patrimônio próprios, a quem é facultada a adoção de qualquer natureza jurídica sem fins lucrativos e vedada a filiação de pessoas físicas ou realização de operações diretamente com o público (GUERRA, 2015: pp.1327-1329). Da mesma forma, a Ley de Ahorro y Crédito Popular (LACP) atribuiu às confederações, também sujeitas a autorização da CNBV, a responsabilidade de administrar os fondos de protección, dedicados a garantir os recursos das instituições a elas filiadas e de seus clientes. 
Os níveis de classificação das SOFIPOs servem como base também para a regulamentação prudencial a que estão sujeitas essas instituições. Dessa maneira, as sociedades financieras populares de nível I devem apresentar capital mínimo de cem mil UDIS para sua constituição. Para as SOFIPOs de nível II, a exigência aumenta para quinhentas mil UDIS, enquanto para as de nível III passa a ser de quatro milhões de UDIS. Finalmente, às sociedades financieras populares de nível IV o capital mínimo exigido é de vinte e dois milhões e quinhentas mil UDIS (Figura 34).

\begin{tabular}{|c|c|c|}
\hline & Volume de Ativos (UDIS) & Capital Mínimo (UDIS) \\
\hline Nível I & Até 15.000 .000 & 100.000 \\
\hline Nível II & $15.000 .000-50.000 .000$ & 500.000 \\
\hline Nível III & $50.000 .000-280.000 .000$ & 4.000 .000 \\
\hline Nível IV & Acima de 280.000 .000 & 22.500 .000 \\
\hline
\end{tabular}

Figura 34. SOFIPOs - Capital mínimo por nível operacional

Fonte: Disposiciones de Carácter General Aplicables a las Entidades de Ahorro y Crédito Popular, Organismos de Integración, Sociedades Financieras Comunitarias y Organismos de Integración Financiera Rural, a que se Refiere la Ley de Ahorro y Crédito Popular. D.O.F. 18/12/2006.

Igualmente, exigências de diversificação de riscos por operações tomam por base os níveis operacionais das SOFIPOs. As instituições pertencentes ao nível I possuem como limite máximo de concentração de risco, seja para pessoa física ou para pessoa jurídica, o equivalente a $7 \%$ de seu capital líquido. As sociedades financieras populares de nível II apresentam como limites de concentração 5\% de seu capital líquido para pessoas físicas e 7\% para pessoas jurídicas. Para as instituições de nível III, o financiamento a pessoas físicas fica restrito a 3\% de seu capital líquido, sendo de $7 \%$ para operações com pessoas jurídicas. SOFIPOs de nível IV apresentam os mesmos percentuais que as de nível III (Figura 35).

\begin{tabular}{|c|c|c|}
\hline & Volume de Ativos (UDIS) & $\begin{array}{c}\text { Concentração de Risco por } \\
\text { Capital Líquido }\end{array}$ \\
\hline Nível I & Até 15.000.000 & $7 \%$ \\
\hline Nível II & $15.000 .000-50.000 .000$ & $\begin{array}{c}5 \% \text { pessoas físicas/7\% pessoas } \\
\text { jurídicas }\end{array}$ \\
\hline Nível III & $50.000 .000-280.000 .000$ & $\begin{array}{c}3 \% \text { pessoas físicas/ 7\% pessoas } \\
\text { jurídicas }\end{array}$ \\
\hline
\end{tabular}




\begin{tabular}{|c|c|c|}
\hline Nível IV & Acima de 280.000 .000 & $\begin{array}{c}3 \% \text { pessoas físicas/ 7\% pessoas } \\
\text { jurídicas }\end{array}$ \\
\hline
\end{tabular}

Figura 35. SOFIPOs - Exigências de concentração de risco por nível operacional

Fonte: Disposiciones de Carácter General Aplicables a las Entidades de Ahorro y Crédito Popular, Organismos de Integración, Sociedades Financieras Comunitarias y Organismos de Integración Financiera Rural, a que se Refiere la Ley de Ahorro y Crédito Popular. D.O.F. 18/12/2006.

Por fim, as exigências de capitalização por riscos e de coeficiente de liquidez são dadas por percentuais semelhantes a todos os níveis, variando conforme seu volume de ativos ou passivos. No primeiro caso, correspondem a $8 \%$ da soma de ativos e outras operações, sendo ponderadas de acordo com o percentual aplicado pela classificação de risco das operações. Já no segundo, equivalem a ao menos $10 \%$ dos passivos de curto prazo (até trinta dias), devendo os recursos reservados para esse fim ser aplicados em depósitos à vista, títulos bancários ou governamentais com prazo semelhante ou inferior a um mês.

\subsubsection{SOFINCOS}

As sociedades financieras comunitarias (SOFINCOs), a exemplo das SOFIPOs, são entidades de microfinanças constituídas como sociedades anônimas de capital variável. Foram criadas a partir da reforma da Ley de Ahorro y Crédito Popular (LACP) realizada em 2009, tendo a primeira SOFINCO sido autorizada oficialmente apenas em $2013^{20}$.

Sua constituição depende de autorização prévia da Comisión Nacional Bancaria de Valores (CNBV) e de certificação concedida por uma federação, sendo esta também responsável pela supervisão auxiliar de SOFINCOs a ela filiadas. Dentre os principais objetivos deste modelo institucional está a incorporação de pequenos produtores agrícolas, de comunidades indígenas e de comunidades rurais marginalizadas ao sistema financeiro formal (ZARATE, 2010: p.47), o que se daria por intermédio da concessão de serviços de poupança e crédito voltados para atividades produtivas do setor rural. Sendo assim, as sociedades financieras comunitarias podem se unir voluntariamente

20 Sociedades Financieras Populares y Sociedades Financieras Comunitarias.Comisión Nacional Bancaria y de Valores. Em: http://www.cnbv.gob.mx/SECTORES-SUPERVISADOS/SECTORPOPULAR/Descripci\%C3\%B3n-del-sector/Paginas/Sociedades-Financieras-Populares.aspx Acesso: 10/07/2016. 
para formar os Organismos de Integración Financiera Rural, cujo funcionamento também deve ser autorizado pela CNBV, e que podem adotar qualquer natureza jurídica sem fins lucrativos, fornecendo serviços similares àqueles das SOFINCOs de atuação individual $^{21}$.

As SOFINCOs contam com capital social formado por ações, com participação mutual e igualitária, bem como com capital comunal integrado via aportes adicionais dos sócios, de outras instituições e do governo federal. Nesse sentido, pessoas jurídicas sem fins lucrativos podem adquirir até $50 \%$ de seu capital social. Essas instituições possuem estrutura de níveis e serviços semelhante àquela das sociedades financieras populares (SOFIPOs), compartilhando também as normas prudenciais a elas aplicadas.

Em seu nível básico, são integradas com dois milhões e quinhentas mil unidades de inversión, podendo oferecer serviços de poupança e crédito somente a seus sócios, sem a necessidade de autorização da CNBV. Superando esse volume de ativos, podem executar outras operações, como transferir dinheiro, receber fundos de terceiros, distribuir recursos de programas governamentais e financiar projetos produtivos (ZARATE, 2010: p.47).

\subsubsection{SOCAPs}

Sociedades cooperativas de ahorro y préstamo (SOCAPs) são intermediárias financeiras sem fins lucrativos, que fornecem serviços de poupança e de crédito para seus sócios ${ }^{22}$. Essa figura institucional foi criada pela Ley de Ahorro y Crédito Popular (LACP), de 2001, com o objetivo de aglutinar parte da vasta gama de instituições atuando na concessão de serviços financeiros populares. Entretanto, em agosto de 2009, sua regulação foi retirada do âmbito da LACP, sendo englobada pela Ley para Regular Actividades de las Sociedades Cooperativas de Ahorro y Préstamo (LRASCAP). Nesse novo quadro, passaram a ser reconhecidas como parte do setor social do sistema financeiro, não podendo apresentar atuação de caráter especulativo ou como intermediários financeiros com fins lucrativos. Além da supervisão da CNBV, as

\footnotetext{
${ }^{21}$ Federaciones. Comisión Nacional Bancaria y de Valores. Em: https://www.gob.mx/cnbv/acciones-yprogramas/federaciones Acesso: 10/12/2017.

22 Sector de Ahorro y Crédito Popular. Comisión Nacional Bancaria y de Valores. Em: https://www.gob.mx/cnbv/acciones-y-programas/sector-de-ahorro-y-credito-popular-48143 Acesso: $16 / 12 / 2017$
} 
SOCAPs são obrigadas a se registrar no Comité de Supervisión Auxiliar (CSA) do Fondo de Protección (FOCOOP), criado em 2009 e responsável por sua supervisão auxiliar $^{23}$.

De modo similar às sociedades financieras populares, as SOCAPs são divididas em níveis operacionais, de acordo com o volume de ativos que operam. A LRASCAP define como de nível operacional básico as instituições com ativos iguais ou inferiores a dois milhões e quinhentas mil unidades de inversión, sendo dispensadas de autorização para funcionamento e da supervisão por parte da CNBV e não contando com proteção de seguro de depósitos. Entre as atividades que são permitidas sob esse nível estão a captação de depósitos à vista, prazo ou poupança, a concessão de empréstimos, a recepção de créditos de entidades financeiras, organismos internacionais, instituições governamentais e de fideicomisos públicos e a distribuição de produtos e serviços de programas governamentais. As SOCAPs de nível básico que ultrapassam o respectivo limite máximo de ativos para atuar de forma não regulada podem continuar a desempenhar suas operações, embora sejam obrigadas a solicitar autorização para funcionar com outro nível operacional ao Comité de Supervisión Auxiliar do Fondo de Protección $^{24}$.

Por sua vez, as sociedades cooperativas de ahorro y préstamo com níveis operacionais de I a IV são aquelas com ativos superiores a dois milhões e quinhentas mil unidades de inversión e que devem obrigatoriamente apresentar autorização da CNBV para oferecer serviços de depósitos, poupança e crédito. Nesse sentido, estão submetidas à supervisão do Fondo de Protección, com a obrigação de apresentar relatórios mensais, trimestrais e anuais com suas informações financeiras.

As SOCAPs de nível I devem contar com um número mínimo de cem sócios, apresentando total de ativos de até dez milhões de unidades de inversión. Dentre os serviços que podem realizar estão captação de depósitos, realização de empréstimos, recepção de empréstimos de instituições financeira, fideicomisos públicos, órgãos

\footnotetext{
23 Sociedades Cooperativas de Ahorro y Préstamo. Comisión Nacional Bancaria y de Valores. Em: http://www.cnbv.gob.mx/SECTORES-SUPERVISADOS/SECTOR-POPULAR/Descripci\%C3\%B3ndel-sector/Paginas/Sociedades-Cooperativas-de-Ahorro-y-Pr\%C3\%A9stamo.aspx Acesso: 16/12/2017.

24 Integración y Autoridad Socap. Em: https://www.gob.mx/cnbv/acciones-y-programas/integracion-yautoridad-socap Acesso: 16/12/2017.
} 
governamentais e organismos internacionais, operação de cartões de débito, pagamento de programas governamentais a seus sócios, entre outros.

Sociedades cooperativas de ahorro y préstamo de níveis operacionais de II a IV devem apresentar ao menos duzentos sócios. As instituições de nível II apresentam limites de ativos entre dez milhões e cinquenta milhões de UDIS, podendo oferecer os mesmos serviços que aquelas de nível I, além de operações de factoring e serviços de caixa de seguros. Operações de nível III apresentam ativos entre cinquenta milhões e duzentos e cinquenta milhões de UDIs, podendo oferecer todos os serviços acima descritos somados a contratos de arrendamento com seus sócios e serviços de caixa e tesouraria. Finalmente, as SOCAPs de nível IV são aquelas com ativos acima dos duzentos e cinquenta milhões de UDIs, englobando todos os serviços das demais e podendo expedir cartões de crédito com base em abertura de conta corrente para seus sócios (Figura 36).

\begin{tabular}{|c|c|c|}
\hline & Volume de Ativos (UDIS) & Atividades \\
\hline Nível I & Até 10.000.000 & $\begin{array}{l}\text { Concessão de crédito, captação } \\
\text { de depósitos, emissão e operação } \\
\text { de cartões de débito, } \\
\text { transferências, concessão de } \\
\text { seguros, distribuição de recursos } \\
\text { de programas governamentais, } \\
\text { concessão de garantias, } \\
\text { recebimento de doações, entre } \\
\text { outros }\end{array}$ \\
\hline Nível II & $10.000 .000-50.000 .000$ & $\begin{array}{c}\text { Contratos de factoring, serviços } \\
\text { de caixa e seguros }\end{array}$ \\
\hline Nível III & $50.000 .000-250.000 .000$ & $\begin{array}{l}\text { Contratos de arrendamento, } \\
\text { serviços de caixa e tesouraria }\end{array}$ \\
\hline Nível IV & Acima de 250.000 .000 & $\begin{array}{l}\text { Expedir cartões de crédito } \\
\text { mediante abertura de conta } \\
\text { corrente de seus clientes, entre } \\
\text { outras }\end{array}$ \\
\hline
\end{tabular}

Figura 36. SOCAPs - Volume de ativos e atividades permitidas por nível operacional

Fonte: SHCP. Disposiciones de Carácter General Aplicables a las Actividades de las Sociedades Cooperativas de Ahorro y Préstamo. D.O.F. 04/06/2012. 
Da mesma forma, a regulamentação prudencial imposta às cooperativas de ahorro y préstamo é estabelecida de acordo com o nível operacional em que estão classificadas. No que diz respeito ao capital mínimo estabelecido, SOCAPs de nível I possuem exigência de cem mil UDIS para sua constituição. As instituições de nível II devem apresentar quinhentas mil UDIS de capital mínimo, enquanto as de nível III requerem quatro milhões de UDIS. Finalmente, as SOCAPs de nível IV são sujeitas a capital mínimo de vinte e dois milhões e quinhentas mil UDIS (Figura 37).

\begin{tabular}{|c|c|c|}
\hline & Volume de Ativos (UDIS) & Capital Mínimo (UDIS) \\
\hline Nível I & Até 10.000 .000 & 100.000 \\
\hline Nível II & $10.000 .000-50.000 .000$ & 500.000 \\
\hline Nível III & $50.000 .000-250.000 .000$ & 4.000 .000 \\
\hline Nível IV & Acima de 250.000.000 & 22.500 .000 \\
\hline
\end{tabular}

Figura 37. SOCAPs - Capital mínimo exigido por nível operacional

Fonte: SHCP. Disposiciones de Carácter General Aplicables a las Actividades de las Sociedades Cooperativas de Ahorro y Préstamo. D.O.F. 04/06/2012.

Disposições de diversificação de riscos de operações aplicáveis às SOCAPs seguem o mesmo padrão. Para as instituições de nível I, operações com indivíduos são limitadas a 7\% de seu capital líquido, enquanto os financiamentos a outras instituições, somados, não podem exceder $20 \%$ do capital líquido da SOCAP. Para aquelas dos níveis II e III, altera-se o limite para financiamento a indivíduos, respectivamente para $5 \%$ e $3 \%$, sendo este último semelhante ao das SOCAPs de nível IV. Para todos os níveis, operações de microcrédito produtivo realizadas com seus sócios ficam limitadas a doze mil UDIS para indivíduos e a vinte mil UDIS para grupos, obedecendo ao teto máximo de duas mil e quinhentas UDIS por sócio nesses casos (Figura 38)

\begin{tabular}{|c|c|c|}
\hline & Volume de Ativos (UDIS) & $\begin{array}{c}\text { Concentração de Risco por } \\
\text { Capital Líquido }\end{array}$ \\
\hline Nível I & Até 10.000 .000 & $\begin{array}{c}7 \% \text { sócios /20\% soma para } \\
\text { instituições }\end{array}$ \\
\hline Nível II & $10.000 .000-50.000 .000$ & $\begin{array}{c}5 \% \text { sócios/20\% soma para } \\
\text { instituições }\end{array}$ \\
\hline Nível III & $50.000 .000-250.000 .000$ & $\begin{array}{c}3 \% \text { sócios/20\% soma para } \\
\text { instituições }\end{array}$ \\
\hline
\end{tabular}




\begin{tabular}{|c|c|c|}
\hline Nível IV & Acima de 250.000 .000 & $\begin{array}{c}3 \% \text { sócios/20\% soma para } \\
\text { instituições }\end{array}$ \\
\hline
\end{tabular}

Figura 38. SOCAPs - Concentração de risco por capital líquido de acordo com o nível operacional Fonte: SHCP. Disposiciones de Carácter General Aplicables a las Actividades de las Sociedades Cooperativas de Ahorro y Préstamo. D.O.F. 04/06/2012.

Por fim, exigências de capitalização por riscos são definidas pelo cálculo de $8 \%$ do total da carteira de crédito, ponderado pelo percentual aplicado para operações de acordo com sua classificação de risco. Em termos de coeficiente de liquidez, deve ser garantida uma posição de ao menos $10 \%$ dos passivos de curto prazo, sendo os recursos aplicados em depósitos à vista, títulos governamentais ou bancários com vencimento em até trinta dias. Essas disposições prudenciais aplicam-se a todos os níveis de SOCAPs.

\subsubsection{SOFOMES}

Por sua vez, as sociedades financieras de objeto múltiple (SOFOMEs), foram criadas em meados de 2006, assumindo a forma de sociedades anônimas e mercantis e não necessitando de autorização para realizar operações de factoring, arrendamento financeiro e concessão de crédito (GUERRA, 2015: p.1326). Como entidades de objeto múltiplo, podem conceder crédito destinado a diferentes atividades, embora seja vedada a captação de recursos do público de maneira direta.

A regulação e supervisão dessas entidades financeiras pela $\mathrm{CNBV}$ ocorrem somente nos casos em que a SOFOME se financia via emissão de dívida inscrita no Registro Nacional de Valores (RNV), em que a instituição apresenta vínculos patrimoniais com instituições de crédito, uniones de crédito ou SOFIPOs, SOFINCOs e SOCAPs de níveis operacionais entre I e IV ou em que instituição solicita de forma voluntária a aprovação da CNBV para se tornar regulada. Nesse último cenário, exigese a subscrição de capital mínimo de dois milhões e quinhentas e oitenta e oito mil unidades de inversión, além de atuação comprovada como SOFOME por período contínuo de três anos e de que setenta por cento da renda por ela apresentada corresponda a seu objeto social.

De todo modo, SOFOMEs reguladas e não reguladas devem apresentar registro na Comisión Nacional para la Protección y Defensa de los Usuarios de Servicios 
Financieros (CONDUSEF) ${ }^{25}$, cujas atribuições envolvem a supervisão e, quando necessário, até mesmo o cancelamento do registro de SOFOMEs que descumpram suas disposições.

Sociedades financieras de objeto múltiple podem se agrupar em organizações próprias, dotadas da possibilidade de definir padrões de conduta e de operações para as instituições associadas. Tais organizações ficam obrigadas a reportar à CNBV quando tiverem conhecimento de violações legais de suas participantes, e suas normas autorregulatórias não devem entrar em desacordo com a legislação vigente.

Em termos de regulação prudencial, SOFOMEs com vínculos patrimoniais com instituições de crédito, sociedades cooperativas de ahorro y préstamo, sociedades financieras populares e sociedades financieras comunitarias, além de uniones de crédito, ficam sujeitas às normas estabelecidas a esses modelos institucionais em relação a exigência de capital, diversificação de riscos, qualificação da carteira de crédito, entre outras.

No que tange a concessão de financiamentos concedidos a indivíduos ou a conjunto de pessoas associadas, os limites máximos em termos do capital contábil das SOFOMEs são ajustados de acordo com o nível de capitalização dessas instituições. Para aquelas com nível de capitalização entre $8 \%$ e $9 \%$, o limite máximo para financiamentos será de 30\%. Para SOFOMEs com capitalização entre 9\% e 10\%, o limite máximo será de $38 \%$. Capitalização entre $10 \%$ e $12 \%$ possibilita financiamentos até o limite de $63 \%$ do capital contábil. Para aquelas com capitalização entre $12 \%$ e 15\%, o limite é elevado para $75 \%$. Finalmente, o limite para as sociedades financieras de objeto múltiple com capitalização acima de $15 \%$ é de $100 \%$ de seu capital contábil (Figura 39).

\begin{tabular}{|c|c|}
\hline Nível de Capitalização & $\begin{array}{c}\text { Limite de Financiamento - Percentual do } \\
\text { Capital Contábil }\end{array}$ \\
\hline $8 \%-9 \%$ & $30 \%$ \\
\hline $9 \%-10 \%$ & $38 \%$ \\
\hline $10 \%-12 \%$ & $63 \%$ \\
\hline $12 \%-15 \%$ & $75 \%$ \\
\hline Acima de $15 \%$ & $100 \%$ \\
\hline
\end{tabular}

Figura 39. SOFOMEs - Limites de financiamneto por nível de capitalização

${ }^{25} \mathrm{https}$ ///www.gob.mx/cnbv/acciones-y-programas/sociedades-financieras-de-objeto-multiple-sofomes 
Fonte: SHCP. Disposiciones de Carácter General Aplicabes a los Almacenes Generales de Depósito, Casas de Cambio, Uniones de Crédito y Sociedades Financieras de Objeto Múltiple Reguladas. D.O.F. 19/01/2009.

\subsubsection{SOFOLES}

As sociedades financieras de objeto limitado (SOFOLEs) eram instituições especializadas na concessão de crédito para atividades produtivas ou setores específicos da economia, atuando também na concessão de microcrédito a pequenas e médias empresas $^{26}$. A criação do modelo data de 1993, sob a égide da Ley de Instituciones de Crédito, como resultado direto das negociações do Acordo de Livre Comércio da América do Norte (NAFTA). Naquele contexto, o estabelecimento de intermediários financeiros de propósito único foi apontado como um dos mecanismos a serem adotados para concretizar a abertura do setor financeiro do país (GUERRA, 2015: p.1324).

As sociedades financieras de objeto limitado dependiam da autorização da Secretaría de Hacienda y Crédito Público (SHCP) e da Comisión Nacional Bancaria de Valores (CNBV) para funcionarem, estando sujeitas também a sua supervisão. Não podiam aceitar depósitos ou poupança do público de forma direta, o que tornava seu financiamento dependente de recursos próprios, de financiamentos dos bancos de desenvolvimento e/ou do mercado financeiro, via instrumentos inscritos no Registro Nacional de Valores (RNV) (GUERRA, 2015: pp.1324-1325).

Em meados de 2006, a reforma da Ley de Instituciones de Crédito acabou por determinar que operações de arrendamento financeiro e factoring deixariam de ser desempenhadas por instituições criadas exclusivamente para esses fins. Logo, definiu-se que as SOFOLEs teriam até a metade de 2013 para se converterem em SOFOMEs ou em bancos. Aquelas que mantivessem as atividades até essa data teriam suas autorizações de funcionamento automaticamente revogadas (MARGARITA, 2016: pp.93-94).

\subsubsection{Uniones de Crédito}

Uniones de crédito são intermediários financeiros não bancários, estruturados como sociedades anônimas e cuja atuação é regulada pela Ley de Uniones de Crédito

${ }^{26}$ SOFOLEs. Comisión Nacional Bancaria y de Valores. Em: http://www.cnbv.gob.mx/SECTORESSUPERVISADOS/OTROS-SUPERVISADOS/Descripci\%C3\%B3n-del-Sector/Paginas/SOFOLES.aspx Acesso: 10/07/2016. 
(LUC). Seu propósito principal é de facilitar o acesso a crédito e investimentos a seus sócios por intermédio de condições mais favoráveis do que aquelas disponíveis no mercado. Elas não contam com a participação ou subsídios governamentais, e seu capital é composto por aportes de seus próprios sócios, tanto pessoas físicas quanto pessoas jurídicas. São sujeitas à autorização e supervisão da Comisión Nacional Bancaria de Valores $(\mathrm{CNBV})^{27}$.

Dentre as disposições da LUC, está a definição de níveis de operação para as uniones de crédito, tomando como base o capital subscrito e de fato pago por essas instituições. Assim, o nível I é composto por aquelas com capital a partir de dois milhões de unidades de inversión. O nível II é formado por aquelas com capital a partir de três milhões de UDIS, enquanto o nível III corresponde àquelas com capital acima de cinco milhões de UDIS ${ }^{28}$.

Os serviços que podem ser concedidos pelas uniones de crédito variam de acordo com o nível em que estão classificadas, conforme indicado na Figura 40. Logo, enquanto a concessão de crédito e a captação de recursos são autorizadas a todos os níveis, operações de factoring e de arrendamento financeiro, bem como a concessão de financiamento a outras uniones de crédito, são permitidas somente àquelas de níveis II e III. Finalmente, a concessão de garantias é restrita ao nível III. A operação nos dois últimos níveis está sujeita à autorização da $\mathrm{CNBV}^{29}$.

\begin{tabular}{|c|c|c|}
\hline Nível & Exigência de Capital (UDIS) & Operações \\
\hline & 2.000 .000 & $\begin{array}{c}\text { Captação de recursos e } \\
\text { concessão de crédito para } \\
\text { sócios e operações mais } \\
\text { básicas }\end{array}$ \\
\hline Nível II & 3.000 .000 & $\begin{array}{c}\text { Factoring, arrendamento } \\
\text { financeiro, concessão de } \\
\end{array}$ \\
& financiamento a outras uniões \\
\hline
\end{tabular}

27 Sector - Uniones de Crédito. Comisión Nacional Bancaria y de Valores. Em: https://www.gob.mx/cnbv/acciones-y-programas/sector-uniones-de-credito Acesso: 11/07/2017.

28 Descripción del Sector - Uniones de Crédito. Comisión Nacional Bancaria y de Valores. Em: http://www.cnbv.gob.mx/SECTORES-SUPERVISADOS/UNIONES-DE-

CREDITO/Paginas/Descripci\%C3\%B3n-del-sector.aspxaspx Acesso: 11/07/2017.

29 Operaciones Permitidas a las Uniones de Crédito. https://www.gob.mx/cnbv/acciones-yprogramas/operaciones-permitidas-a-las-uniones-de-credito Acesso: 11/072017 


\begin{tabular}{|c|c|c|}
\hline & & de crédito \\
\hline Nível III & 5.000 .000 & Concessão de garantias \\
\hline
\end{tabular}

Figura 40. Uniones de Crédito - Exigências de capital e operações permitidas por nível Fonte: SHCP. Disposiciones de Carácter General Aplicabes a los Almacenes Generales de Depósito, Casas de Cambio, Uniones de Crédito y Sociedades Financieras de Objeto Múltiple Reguladas. D.O.F. 19/01/2009.

\subsection{Resultados}

Analisando a legislação mexicana acima discutida à luz das hipóteses previamente elencadas sobre os efeitos da regulação financeira sobre o setor de microfinanças, podemos traçar alguns dos efeitos esperados em termos de estrutura do setor, alcance e autossustentabilidade financeira das instituições que operam microcrédito no país.

Para os modelos institucionais do sector de ahorro y crédito popular aqui considerados, ou seja, sociedades financieras populares (SOFIPOs) e sociedades cooperativas de ahorro y préstamo (SOCAPs), espera-se que os níveis relativamente baixos de exigência de capital de entrada, estabelecidos em cem mil UDIS, resultariam em grande quantidade de instituições reguladas e de pequeno porte. Em consequência haveria competição elevada, com incentivos para a busca por clientes de maior renda. Exigências baixas também poderiam atrair instituições mais propensas a riscos, como parece ter ocorrido no caso da sociedade financiera popular Ficrea.

Por sua vez, a existência de estruturas regulatórias escalonadas para SOCAPs e SOFIPOs, ao estabelecer trajetórias claras para a possibilidade de prestação de serviços distintos e com maior potencial lucrativo dentro desses próprios modelos institucionais, estimularia um número relativamente significativo de instituições a buscar os níveis operacionais mais elevados. Entretanto, observa-se que o nível de capital mínimo exigido para esses modelos institucionais aumenta sensivelmente entre os níveis, em especial no nível III, com valor mínimo de quatro milhões de unidades de inversión, e no nível IV, com vinte e dois milhões e quinhentas mil UDIS. Tal fator poderia desencorajar planos de graduação de nível.

Em contrapartida, sociedades financieras de objeto múltiple (SOFOMEs) não possuem estrutura escalonada em níveis, mas apresentam exigência de capital mínimo de dois milhões e quinhentas e oitenta e oito mil unidades de inversión quando desejam se transformar de instituição não regulada para instituição regulada. Em comparação com a exigência mínima para os níveis iniciais de SOFIPOs e SOCAPs, trata-se de um 
valor muito mais elevado com potencial para dissuadir tentativas de transformação em SOFOMEs reguladas.

A possibilidade de sociedades financieras de objeto múltiple atuarem de forma não regulada, bastando sua inscrição em registro mantido pela CONDUSEF, enquanto SOFOMEs reguladas são submetidas à supervisão direta da CONDUSEF e da Comisión Nacional Bancaria de Valores, são outros incentivos para que SOFOMEs busquem evitar a regulação. Assim, antecipa-se um número reduzido de sociedades financieras de objeto múltiple reguladas.

Enfim, uniones de crédito possuem sua estrutura de regulação escalonada, com seus três níveis determinados de acordo com o capital subscrito. A exemplo do que ocorre nos modelos do sector de ahorro y crédito popular, o conjunto de operações permitidas é ampliado quanto mais elevado o nível da instituição. Dessa maneira, existiriam incentivos para a busca por graduação de nível por parte dessas instituições como forma de fornecer uma gama mais elevada de serviços, por vezes também mais lucrativos. Os valores mínimos de capital subscrito são relativamente elevados, totalizando dois milhões de UDIS para o primeiro nível, três milhões de unidades de inversión para o segundo nível e cinco milhões de UDIS para o último nível. Logo, prevê-se um modelo com número reduzido de instituições de grande porte. A Figura 41 sumariza os resultados esperados em termos de estrutura do setor mexicano de microfinanças:

\begin{tabular}{|c|c|c|}
\hline \multicolumn{3}{|c|}{ Estrutura do Setor de Microcrédito } \\
\hline Modelo Institucional & Regulação Encontrada & Efeito Esperado \\
\hline \multirow{3}{*}{ SOFIPOs } & $\begin{array}{l}\text { Baixo nível de exigência de } \\
\text { capital de entrada }\end{array}$ & $\begin{array}{l}\text { Grande quantidade de } \\
\text { instituições de pequeno porte }\end{array}$ \\
\hline & Estrutura regulatória escalonada & $\begin{array}{c}\text { Distribuição das instituições em } \\
\text { níveis operacionais mais } \\
\text { elevados }\end{array}$ \\
\hline & $\begin{array}{l}\text { Exigência de capital mínimo } \\
\text { aumentando entre níveis } \\
\text { operacionais }\end{array}$ & $\begin{array}{l}\text { Concentração em níveis } \\
\text { operacionais mais baixos }\end{array}$ \\
\hline \multirow[b]{2}{*}{ SOCAPs } & $\begin{array}{l}\text { Baixo nível de exigência de } \\
\text { capital de entrada }\end{array}$ & $\begin{array}{l}\text { Grande quantidade de } \\
\text { instituições de pequeno porte }\end{array}$ \\
\hline & Estrutura regulatória escalonada & $\begin{array}{c}\text { Distribuição das instituições em } \\
\text { níveis operacionais mais } \\
\text { elevados }\end{array}$ \\
\hline
\end{tabular}




\begin{tabular}{|c|c|c|}
\hline & $\begin{array}{c}\text { Exigência de capital mínimo } \\
\text { aumentando entre níveis } \\
\text { operacionais }\end{array}$ & $\begin{array}{c}\text { Concentração em níveis } \\
\text { operacionais mais baixos }\end{array}$ \\
\hline SOFOMEs & $\begin{array}{c}\text { Exigência elevada de capital } \\
\text { mínimo }\end{array}$ & $\begin{array}{c}\text { Número reduzido de instituições } \\
\text { de grande porte }\end{array}$ \\
\hline Uniones de Crédito & Exigência elevada de capital \\
mínimo & $\begin{array}{c}\text { Número reduzido de instituições } \\
\text { de grande porte }\end{array}$ \\
\hline
\end{tabular}

Figura 41. Resultados esperados em termos de estrutura do setor de microcrédito mexicano por tipo de regulação

Fonte: Elaboração própria a partir da legislação discutida

Em relação a limites de concentração de risco, uma possibilidade é que limitar valores para a realização de operações individuais resulte em maiores custos para as instituições, dado que, em termos comparativos, operações de crédito de maiores montantes possuem custos unitários menores do uma soma de diversas operações de crédito de pequena escala. Embora a autossustentabilidade financeira pudesse ser prejudicada, haveria incentivos para o alcance a um maior número de clientes.

No caso das SOFIPOs e SOCAPs, instituições do sector de ahorro y crédito popular, os limites de concentração de risco tornam-se mais restritivos conforme seu nível operacional, possivelmente desestimulando a busca pela graduação de nível. Logo, resultados esperados para as sociedades financieras populares e para as sociedades cooperativas de ahorro y préstamo são de menor autossustentabilidade financeira e maior alcance.

No caso das sociedades financieras de objeto múltiple (SOFOMEs), as restrições de financiamento por operação são reduzidas paulatinamente, de acordo com o índice de capitalização da instituição, até que seja atingida a possibilidade de realização de operação no valor de até $100 \%$ de seu capital contábil. Tal escalonamento poderia servir de estímulo para a busca por maior capitalização por parte das SOFOMEs. Nesse sentido, espera-se observar maior autossustentabilidade financeira e menor alcance no que diz respeito a este modelo institucional.

Exigências de capitalização por riscos para SOFIPOs e SOCAPs, estabelecidas em $8 \%$ da soma dos ativos e de outras operações com ponderação percentual aplicada de acordo com a classificação de risco de cada operação, resultariam em menores retornos para essas instituições, possivelmente prejudicando tanto a 
autossustentabilidade financeira quanto a amplitude do alcance apresentado por essas instituições. Os coeficientes de liquidez exigidos para as sociedades financieras populares e para as sociedades cooperativas de ahorro y préstamo, com aplicação de $10 \%$ do valor dos passivos de curto prazo em depósitos à vista, títulos bancários ou governamentais, apresentariam efeitos semelhantes. Tais implicações seriam ainda reforçadas pelos custos operacionais incorridos por essas instituições devido a seus esforços de adequação a normas prudenciais e às exigências de relatórios periódicos impostas pela supervisão (neste caso, também existentes para as SOFOMEs e para as uniones de crédito). Isso posto, espera-se menores autossustentabilidade financeira e alcance para as SOFIPOs e SOCAPs. A Figura 42 reúne os resultados esperados em termos de alcance e autossustentabilidade financeira:

\begin{tabular}{|c|c|c|}
\hline \multicolumn{3}{|c|}{ Alcance e Autossustentabilidade Financeira do Setor de Microcrédito } \\
\hline Modelo Institucional & Regulação Encontrada & Efeito Esperado \\
\hline \multirow{3}{*}{ SOFIPOs } & $\begin{array}{l}\text { Limites restritivos de } \\
\text { concentração de risco }\end{array}$ & $\begin{array}{c}\text { Menor autossustentabilidade } \\
\text { financeira e maior alcance }\end{array}$ \\
\hline & $\begin{array}{c}\text { Exigência de capitalização por } \\
\text { riscos }\end{array}$ & $\begin{array}{c}\text { Menor autossustentabilidade } \\
\text { financeira e menor alcance }\end{array}$ \\
\hline & $\begin{array}{c}\text { Exigências de coeficientes de } \\
\text { liquidez }\end{array}$ & $\begin{array}{c}\text { Menor autossustentabilidade } \\
\text { financeira e menor alcance }\end{array}$ \\
\hline \multirow{3}{*}{ SOCAPs } & $\begin{array}{l}\text { Limites restritivos de } \\
\text { concentração de risco }\end{array}$ & $\begin{array}{c}\text { Menor autossustentabilidade } \\
\text { financeira e maior alcance }\end{array}$ \\
\hline & $\begin{array}{c}\text { Exigência de capitalização por } \\
\text { riscos }\end{array}$ & $\begin{array}{l}\text { Menor autossustentabilidade } \\
\text { financeira e menor alcance }\end{array}$ \\
\hline & $\begin{array}{c}\text { Exigências de coeficientes de } \\
\text { liquidez }\end{array}$ & $\begin{array}{l}\text { Menor autossustentabilidade } \\
\text { financeira e menor alcance }\end{array}$ \\
\hline SOFOMEs & $\begin{array}{l}\text { Limites de concentração de risco } \\
\text { reduzidos conforme capitalização }\end{array}$ & $\begin{array}{l}\text { Maior autossustentabilidade } \\
\text { financeira e menor alcance }\end{array}$ \\
\hline
\end{tabular}

Figura 42. Resultados esperados em termos de alcance e autossustentabilidade financeira do setor de microcrédito mexicano por tipo de regulação

Fonte: Elaboração própria a partir da legislação discutida

\subsubsection{Análise Empírica}

Os dados empíricos de instituições que operam microfinanças no México foram levantados a partir dos Boletins Estatísticos divulgados pela Comisión Nacional 
Bancaria y de Valores (CNBV), possibilitando uma análise da evolução de cada modelo institucional ao longo do tempo e em relação às variáveis de alcance, sustentabilidade financeira e estrutura do setor em termos de número de instituições. Entretanto, tratamse de dados autorreportados que, embora contem com avaliação e parametrização da Comisión, apresentam certas inconsistências em aspectos como cumprimento de certas instituições da periodicidade exigida para reportar as informações.

Com exceção da Figura 43, todas aquelas envolvendo valores monetários foram deflacionadas utilizando-se o Índice nacional de precios al consumidor (INPC), sendo atualizadas de acordo com os valores reais correspondentes à última data registrada na série de dados.

\subsubsection{Estrutura do Setor}

Em relação ao tamanho relativo do setor de microcrédito no México, a Figura 43 indica um montante total de aproximadamente cento e cinco milhões de pesos de carteira de carteira de crédito, valor superior àquele apresentado por uniones de crédito, com pouco mais de quarenta e sete milhões de pesos. Em contrapartida, as SOFOMEs reguladas apresentam a terceira maior carteira de crédito, com cerca de trezentos e trinta e dois milhões de pesos. São os bancos múltiplos, porém, que apresentam a maior carteira de crédito, totalizando quatro bilhões e trezentos e setenta e seus milhões de pesos. É importante ressaltar, contudo, que os dados não fazem distinção entre operações de crédito tradicionais e operações de microcrédito.

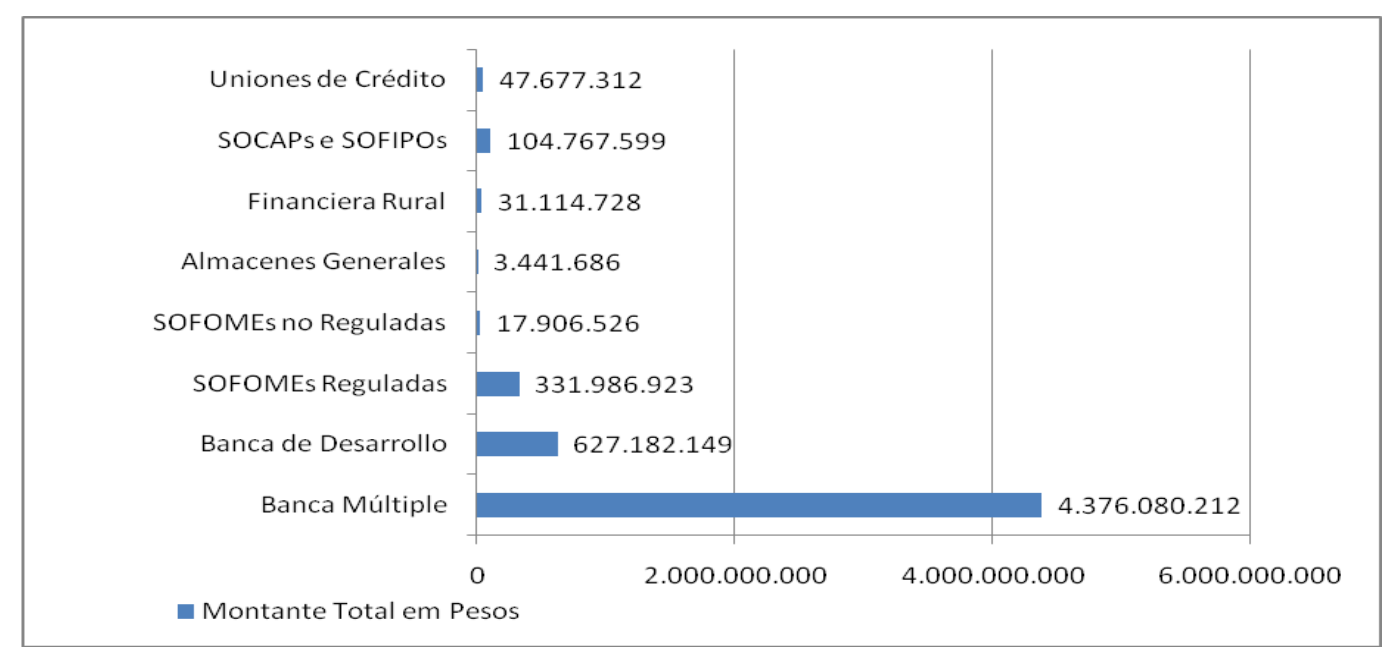

Figura 43. Valor total de carteira de crédito por modelo institucional - setembro de 2017 Fonte: CNBV (Comisión Nacional Bancaria y de Valores). Boletínes Estadísticos. 
No que diz respeito às sociedades financieras populares (SOFIPOs), a Figura 44 indica um aumento tímido no número de instituições entre 2009, ano em que foi realizada a reforma da Ley de Ahorro y Crédito Popular (LACP), e o ano de 2011. No entanto, após esse período, o total de SOFIPOs se estabilizou, ainda que nunca ultrapassando o patamar de quarenta e cinco.

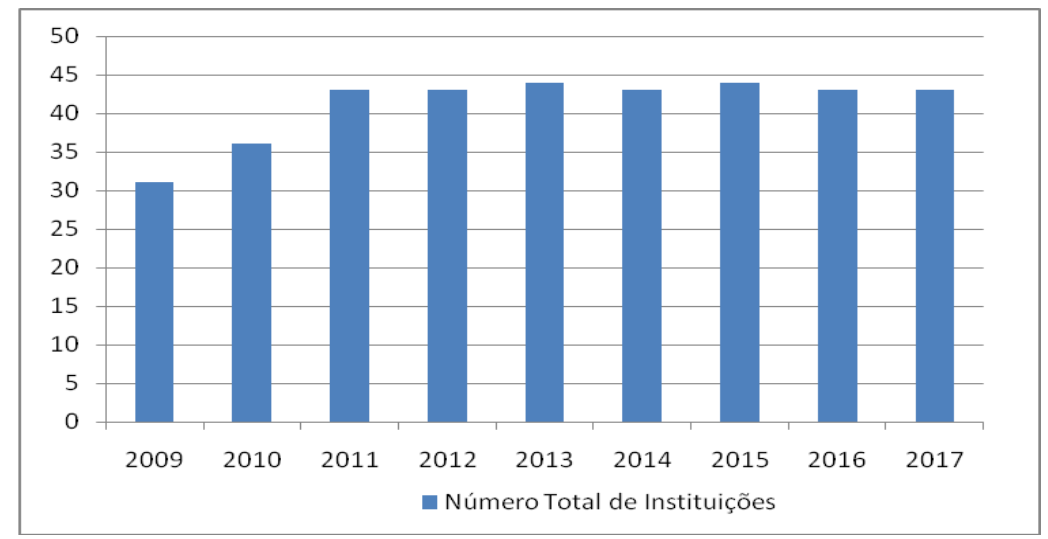

Figura 44. Evolução anual do número de SOFIPOs

Fonte: Elaboração própria a partir de Boletínes Estadísticos de Sociedades Financieras Populares. Em: http://portafoliodeinformacion.cnbv.gob.mx/eacp1/Paginas/boletines.aspx Acesso: 12/12/2017

Da mesma forma, a Figura 45 aponta para uma concentração significativa de SOFIPOs no nível operacional I, seguindo a tendência de aumento no número de instituições entre 2009 e 2010. O nível III apresentou a segunda maior concentração de superada, a partir de 2014, pelas sociedades financieras populares de nível II. Também a partir de 2014 surgiu uma única SOFIPO de nível IV, se mantendo até 2017.

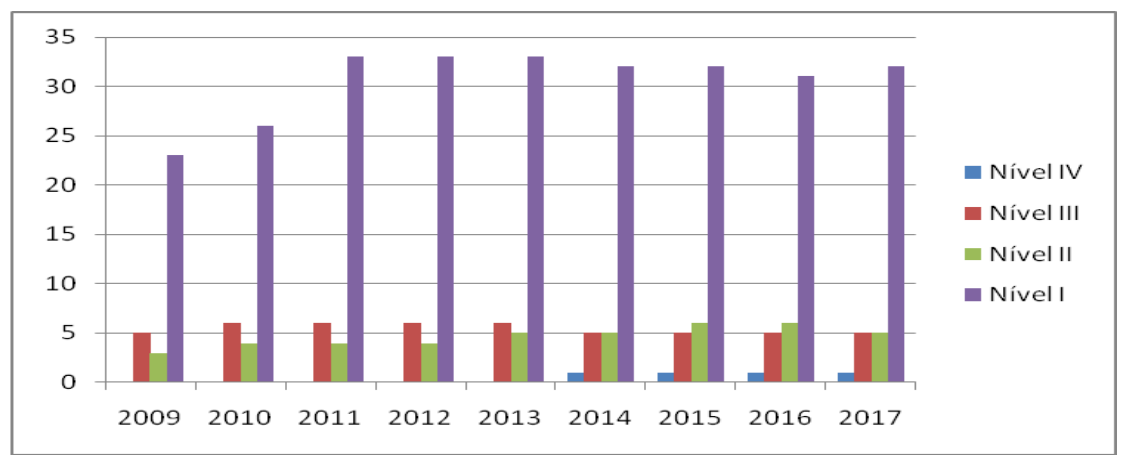

Figura 45. Evolução anual do número de SOFIPOs por nível operacional

Fonte: Elaboração própria a partir de Boletínes Estadísticos de Sociedades Financieras Populares. Em: http://portafoliodeinformacion.cnbv.gob.mx/eacp1/Paginas/boletines.aspx Acesso: 12/12/2017 
Como pode ser observado na Figura 46, em se tratando das sociedades cooperativas de ahorro y préstamo (SOCAPs), houve um crescimento sensível no total de instituições entre 2009, ano em que houve a reforma da LACP e foi promulgada a Ley para Regular las Actividades de las Sociedades Cooperativas de Ahorro y Préstamo (LRASCAP), e o ano de 2015, passando de quarenta e duas para cento e quarenta e seis. O ano de 2013 se destacou nesse sentido, com um aumento de quarenta e nove instituições. Em dezembro de 2017, foram registradas cento e cinquenta e três SOCAPs.

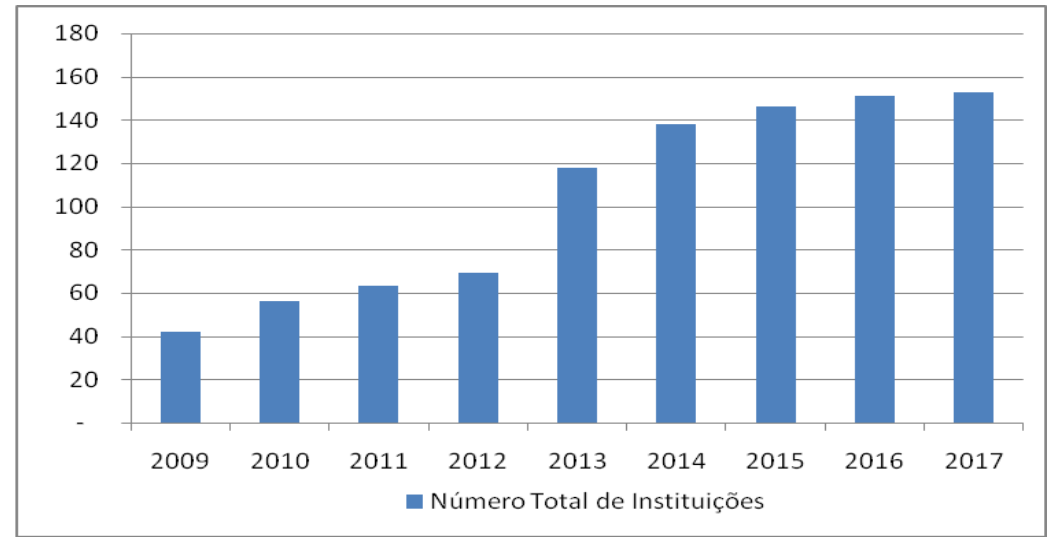

Figura 46. Evolução anual do número de SOCAPs

Fonte: Elaboração própria a partir de CNBV. Boletínes Estadísticos de Sociedades Cooperativas de Ahorro y Préstamo. Em: http://portafoliodeinformacion.cnbv.gob.mx/eacp1/Paginas/boletines.aspx Acesso: 15/12/2017

O padrão de evolução do número de SOCAPs mostra-se distinto do apresentado pelas sociedades financieras populares (SOFIPOs) também em relação à distribuição do número de instituições entre os diferentes níveis operacionais. Conforme apontado pela Figura 47, as sociedades cooperativas de ahorro y préstamo apresentaram uma divisão realmente mais equitativa entre níveis operacionais ao longo do tempo, exceção feita ao nível IV, com apenas uma instituição desde dezembro de 2013. É curioso notar que o nível I não deteve a maior concentração de instituições em nenhum dos anos, o que ocorreu para o nível III entre 2009 e 2012 e para o nível II entre 2013 e 2017. 


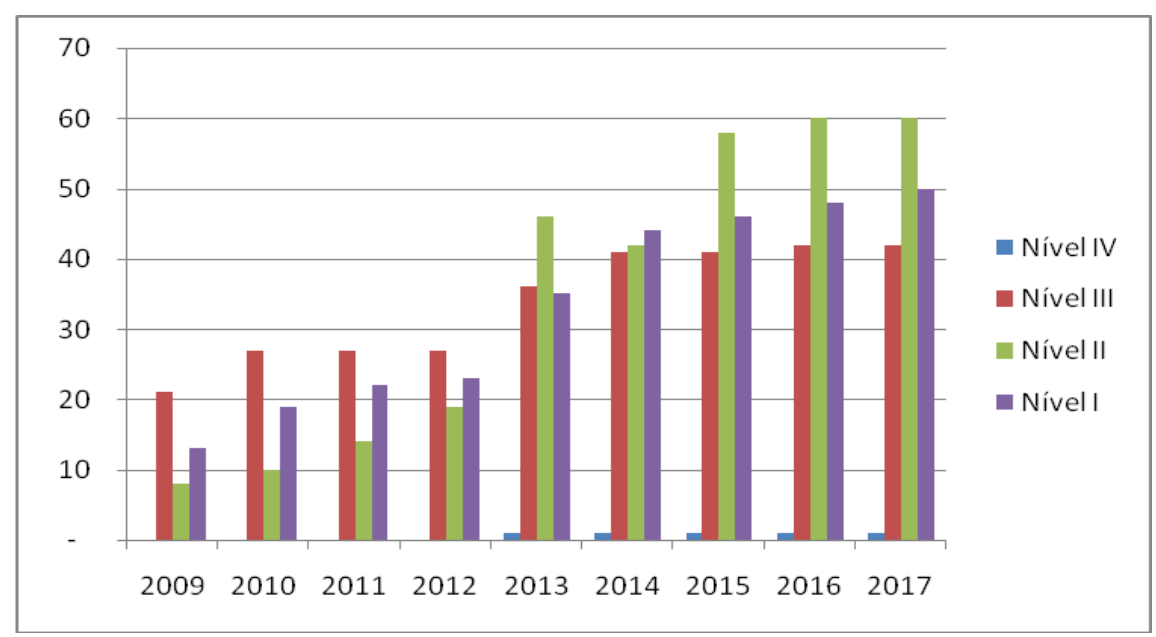

Figura 47. Evolução anual do número de SOCAPs por nível operacional

Fonte: Elaboração própria a partir de CNBV. Boletínes Estadísticos de Sociedades Cooperativas de Ahorro y Préstamo. Em: http://portafoliodeinformacion.cnbv.gob.mx/eacp1/Paginas/boletines.aspx Acesso: $15 / 12 / 2017$

No caso das sociedades financieras de objeto múltiple, a Figura 48 indica que o número de instituições reguladas sob esse modelo atingiu seu ápice em 2016, com um total de apenas trinta e cinco desde o início da série estatística disponibilizada pela CNBV.

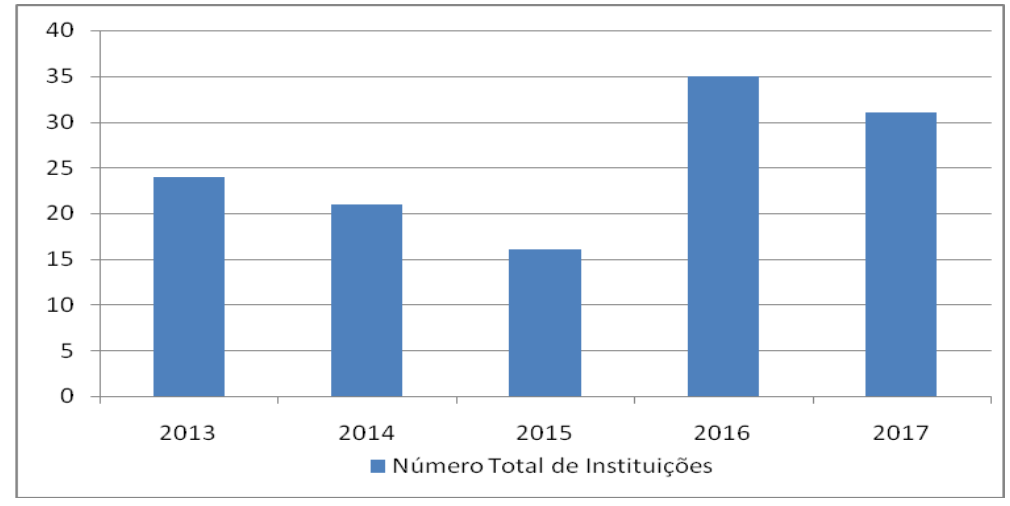

Figura 48. Evolução anual do número de SOFOMEs

Fonte: Elaboração própria a partir de CNBV. Boletínes Estadísticos de Sociedades Financieras de Objeto Múltiple, Entidades Reguladas. Em: http://portafoliodeinformacion.cnbv.gob.mx/SOFOLES/Paginas/bolestadis.aspx Acesso: 11/12/2017

Por fim, em relação às uniones de crédito, a Figura 49 aponta para uma tendência de declínio no total de instituições que reportaram à $\mathrm{CNBV}$ ao longo do tempo, número que caiu de cento e dezessete no ano de 2009 para oitenta e seis em 
2017. Entretanto, tal fato se deve mais em decorrência de problemas de envio de relatórios pela uniones de crédito à $\mathrm{CNBV}$.

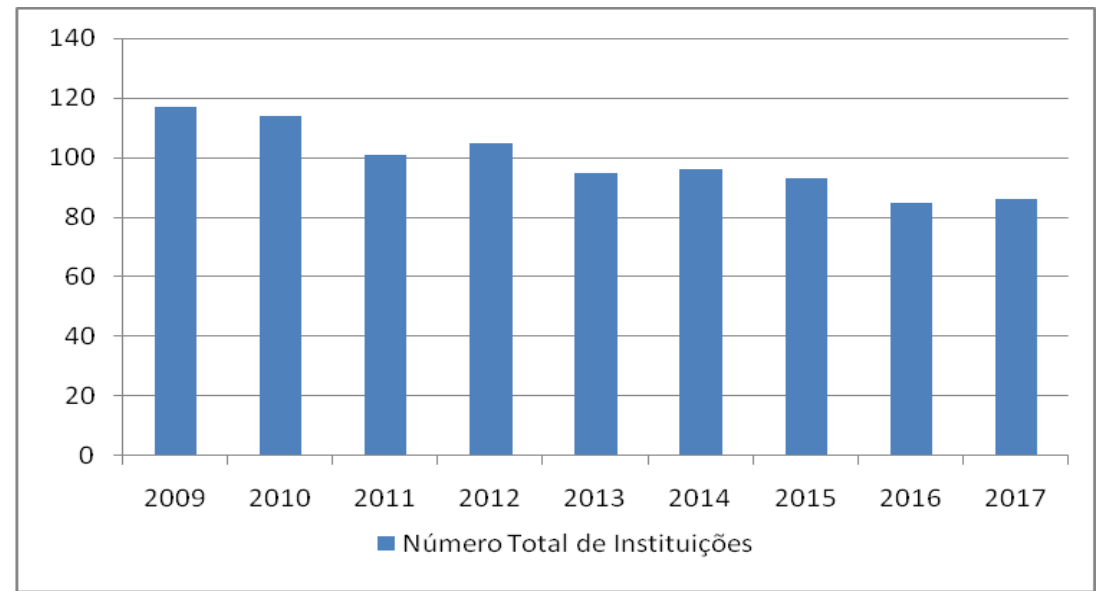

Figura 49. Evolução anual do número de Uniones de Crédito

Fonte: Elaboração própria a partir de CNBV. Boletínes Estadísticos de Uniones de Crédito. Em: http://portafoliodeinformacion.cnbv.gob.mx/oaacs1/Paginas/boletines_uc.aspx Acesso: 09/12/2017

Observamos, portanto, que os resultados esperados para as SOFIPOs em termos de um número substancial de instituições financeiras de pequeno porte não se comprovaram. O mesmo ocorreu com as expectativas de um total elevado significativo de sociedades financieras populares em níveis operacionais mais elevados, uma possível consequência das dificuldades de se angariar o capital necessário e o nível de ativos exigido para efetuar a transição.

Para as SOCAPs, por outro lado, a hipótese de um número elevado de instituições parece se comprovar, em especial a partir da promulgação da LRASCAP no ano de 2009. O padrão para esse modelo institucional mostra-se distinto também em relação aos efeitos da estrutura escalonada de regulação, com uma distribuição mais equitativa entre seus diferentes níveis. O nível IV aparece como exceção a essa tendência, um possível indicativo das altas exigências de capital e de ativos.

Conforme esperado, devido à exigência elevada de capital inicial e às possibilidades de atuação como instituições não reguladas, as sociedades financieras de objeto múltiple reguladas são pouco numerosas. Em contrapartida, os efeitos esperados não se comprovam para as uniones de crédito, com as altas exigências de capital mínimo não influenciando negativamente no número de instituições. 


\subsubsection{Alcance}

Acerca das sociedades financieras populares (SOFIPOs), a Figura 50 aponta um crescimento contínuo no número de clientes ao longo do tempo. De um total de aproximadamente um milhão e seiscentos e vinte mil atendidos em 2009, SOFIPOs reportaram cerca de dois milhões e setecentos e quarenta mil clientes em dezembro de 2013. Por fim, em dezembro de 2017, elas possuíam um total aproximado de três milhões e setecentos e sessenta e cinco mil clientes.

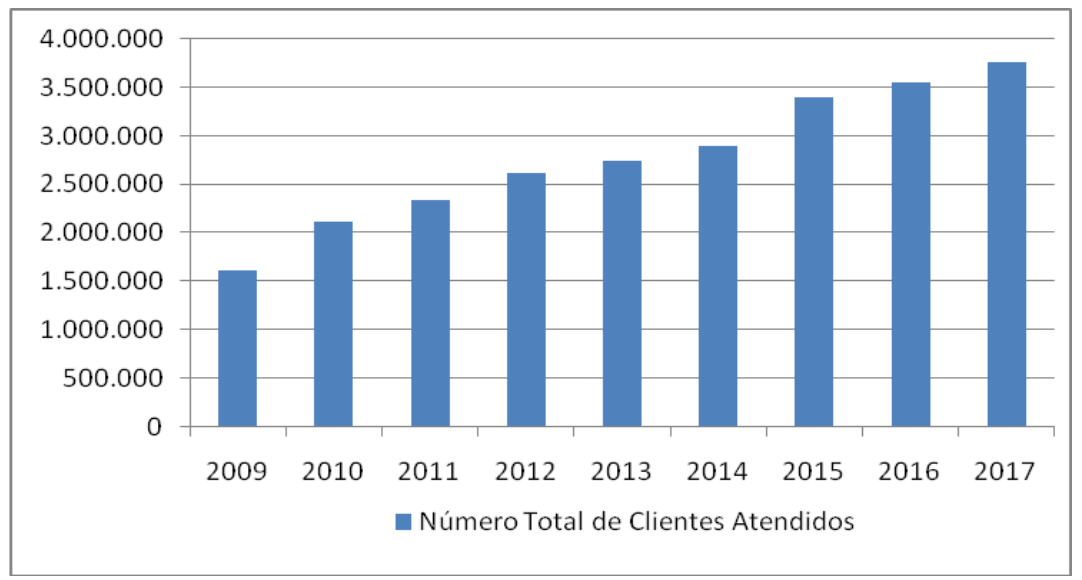

Figura 50. Evolução anual do número total de clientes atendidos por SOFIPOs

Fonte: Elaboração própria a partir de Boletínes Estadísticos de Sociedades Financieras Populares. Em: http://portafoliodeinformacion.cnbv.gob.mx/eacp1/Paginas/boletines.aspx Acesso: 12/12/2017

As sociedades cooperativas de ahorro y préstamo (SOCAPs) também apresentam um número relativamente elevado de clientes, com aumento ainda mais significativo no período para os quais existem dados disponíveis. O número de clientes, que girava em torno de dois milhões e oitocentos e sessenta mil em dezembro 2009, atingiu cerca de três milhões e setecentos e trinta e cinco mil já em dezembro de 2012. Em dezembro de 2013, foi reportado um total de quatro milhões e seiscentos e cinquenta e seis mil clientes atendidos, número que passou para seis milhões e cento e cinquenta mil em dezembro de 2017 (Figura 51). 


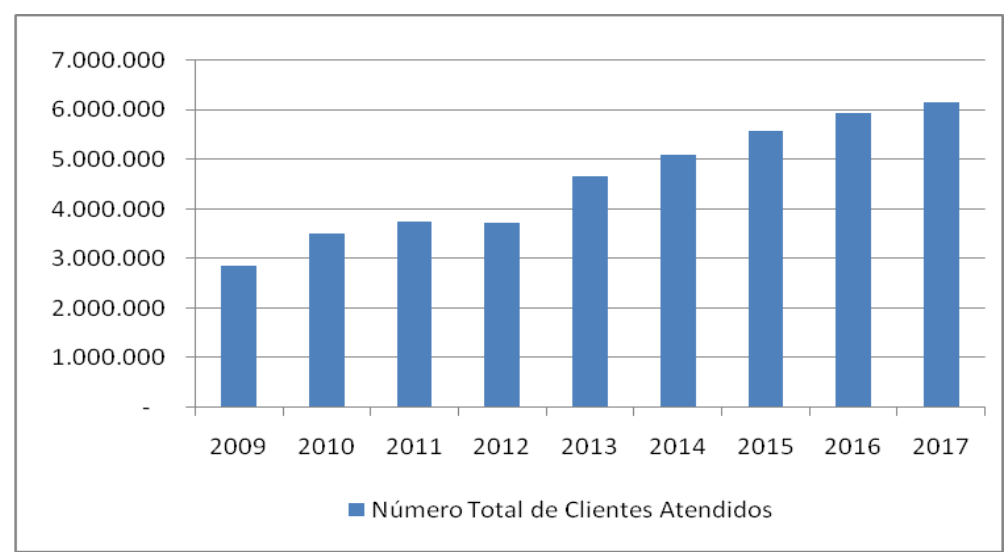

Figura 51. Evolução anual do número total de clientes atendidos por SOCAPs

Fonte: Elaboração própria a partir de CNBV. Boletínes Estadísticos de Sociedades Cooperativas de Ahorro y Préstamo. Em: http://portafoliodeinformacion.cnbv.gob.mx/eacp1/Paginas/boletines.aspx Acesso: 15/12/2017

Os resultados esperados para as SOFIPOs em termos de alcance parecem se comprovar em relação à regulação relativa a diversificação de risco, tendo em vista o grande crescimento no número de clientes entre 2009 e 2017. Por conseguinte, as expectativas de alcance reduzido derivadas de exigências de capitalização por riscos e por coeficiente de liquidez não se concretizaram. Tais efeitos são replicados no caso das SOCAPs, embora o aumento no número de clientes ao longo dos anos tenha sido significativamente maior para este modelo institucional.

\subsubsection{Autossustentabilidade Financeira}

No que tange a autossustentabilidade financeira das instituições, a CNBV disponibiliza dados acerca do Retorno sobre Ativos (ROA) apresentado pelas instituições. Tal indicador busca mensurar a eficiência com que a instituição consegue gerar lucros a partir dos ativos que tem disponíveis. Em geral, quanto maior o percentual apresentado, maior sua eficiência nesse quesito.

Destarte, a Figura 52 demonstra certa volatilidade no ROA reportado pelas sociedades financieras populares ao longo do tempo. Nota-se que o índice nunca atingiu a casa dos 1,5\%, embora tenha se aproximado nos anos de 2010 e, em especial, de 2017. Em compensação, mostrou-se negativo em 2009, 2013 e 2014 e, principalmente, em dezembro de 2011, quando chegou a $-1,22 \%$. 


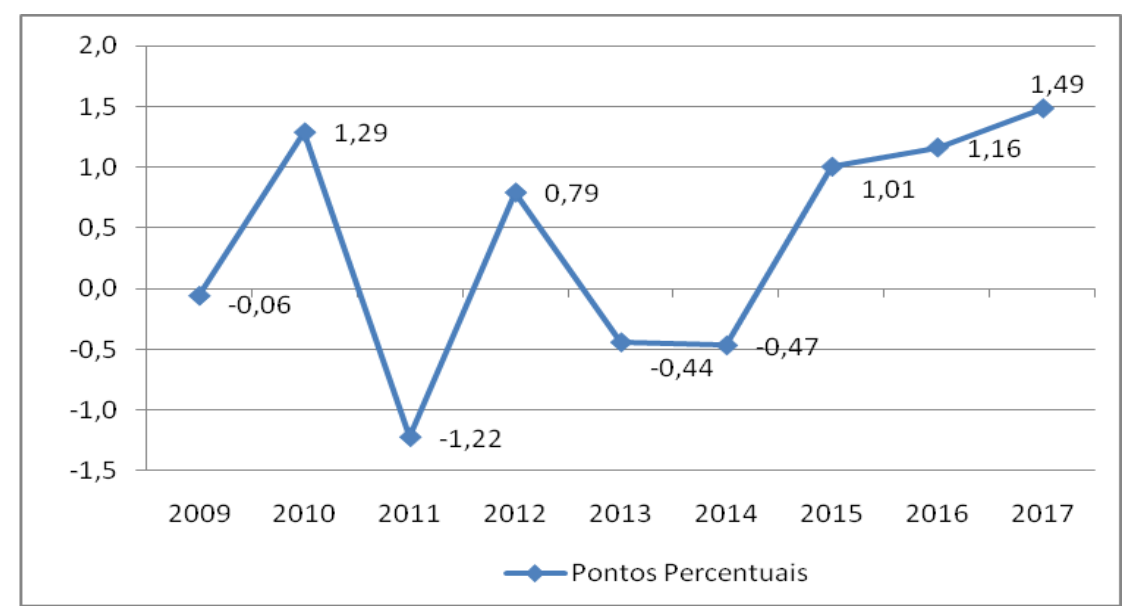

Figura 52. Evolução anual do retorno sobre ativos (ROA) das SOFIPOs

Fonte: Elaboração própria a partir de Boletínes Estadísticos de Sociedades Financieras Populares. Em: http://portafoliodeinformacion.cnbv.gob.mx/eacp1/Paginas/boletines.aspx Acesso: 12/12/2017

A Figura 53 demonstra que a taxa de retorno sobre ativos das sociedades cooperativas de ahorro y préstamo apresentou-se mais elevado do que no caso das SOFIPOs, aumentando de forma mais ou menos estável ao longo do período reportado. Enquanto seu valor mínimo foi atingido no ano de 2009, com ROA de $-0,98 \%$, o valor reportado passou para $0,81 \%$ já em 2010. Em dezembro de 2014, o ROA apresentado foi de $1,59 \%$, ultrapassando a barreira dos 2\% em 2016 e atingindo seu ápice em 2017 , com ROA de $2,4 \%$.

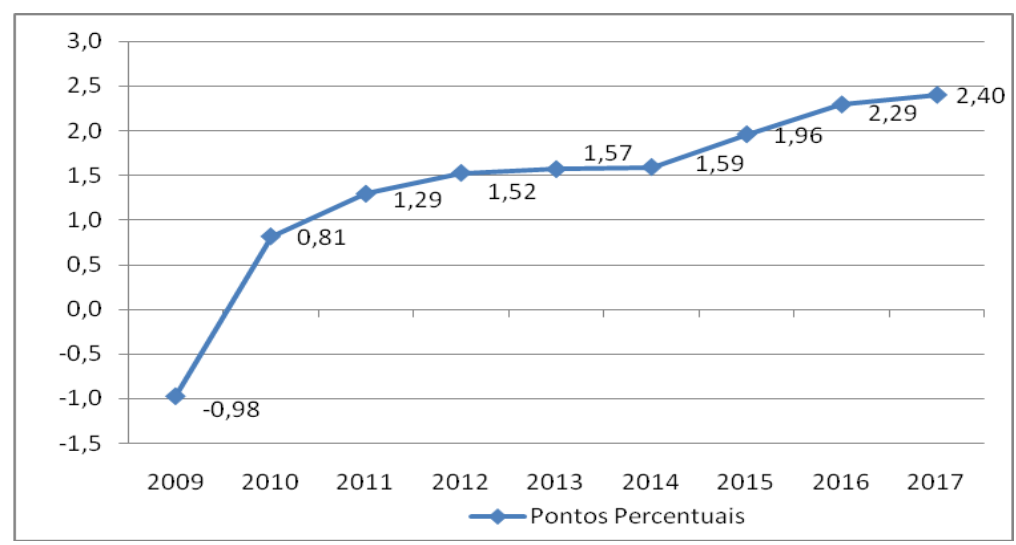

Figura 53. Evolução anual do retorno sobre ativos (ROA) das SOCAPs

Fonte: Elaboração própria a partir de CNBV. Boletínes Estadísticos de Sociedades Cooperativas de Ahorro y Préstamo. Em: http://portafoliodeinformacion.cnbv.gob.mx/eacp1/Paginas/boletines.aspx Acesso: $15 / 12 / 2017$ 
A Figura 54 aponta para um queda significativa no percentual de retorno sobre ativos para as SOFOMEs reportados para dezembro 2013 e dezembro 2015, passando de $2,47 \%$ para apenas $0,16 \%$. Apesar de uma brusca recuperação em 2016, com ROA reportado de 2,34\%, houve nova queda para 1,54\% em 2017.

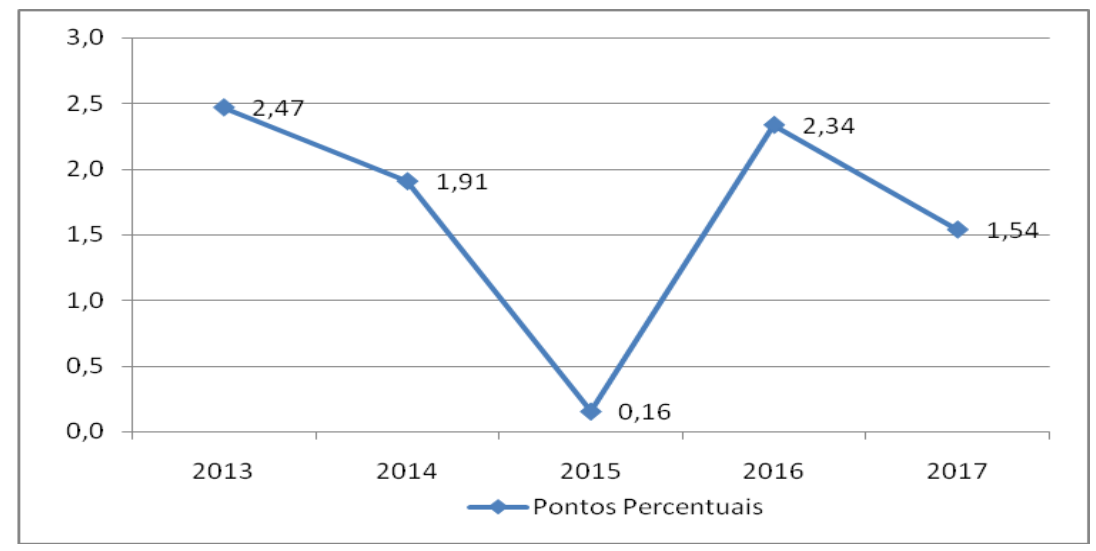

Figura 54. Evolução anual do retorno sobre ativos (ROA) das SOFOMEs

Fonte: Elaboração própria a partir de CNBV. Boletínes Estadísticos de Sociedades Financieras de Objeto Múltiple, Entidades Reguladas. Em: http://portafoliodeinformacion.cnbv.gob.mx/SOFOLES/Paginas/bolestadis.aspx Acesso: 11/12/2017

Assim, no caso das sociedades financieras populares, os dados empíricos parecem corroborar a hipótese de menor autossustentabilidade financeira em decorrência de limites de diversificação de riscos e de exigências de capitalização por riscos e de coficiente de liquidez. Porém, o oposto ocorre no caso das SOCAPs, cujo retorno sobre ativos reportado apresentou crescimento consistente, passando de uma taxa negativa de -0,98\% em 2009 para 2,4\% em dezembro de 2017.

Finalmente, as expectativas de maior autossustentabilidade financeira por parte das sociedades financieras de objeto múltiple (SOFOMEs) parecem se concretizar, a despeito de queda considerável no retorno sobre ativos apresentado no ano de 2015.

\section{Considerações Finais}

O microcrédito, em sua vertente moderna, foi constituído com o intuito de atender as necessidades de indivíduos excluídos dos mercados de crédito tradicionais devido a fatores como ausência de documentação, ausência de colateral, dificuldades geográficas de acesso a instituições financeiras formais e a ponderações acerca dos 
riscos e da indesejabilidade, muitas vezes considerados elevados pelos bancos, de se emprestar para indivíduos mais pobres.

Por meio de técnicas intensivas em trabalho e em informação, baseadas em avaliação de caráter, estimativas de fluxos de caixa, atuação no local de trabalho dos tomadores e estabelecimento de contratos de responsabilidade conjunta e de estrutura de incentivos para a adimplência, entidades pioneiras mostraram ser possível atender as necessidades de crédito dos excluídos dos mercados formais.

Ao longo das décadas, as concepções referentes ao microcrédito sofreram transformações significativas. Muitas instituições passaram a atuar no setor tendo em vista somente a obtenção de lucro, enquanto outras buscaram formas de conciliar objetivos financeiros e sociais, algumas com relativo sucesso. A partir da década de 1990, houve uma redução na dependência de doações por parte de diversos atores do setor, em paralelo à adoção de uma visão mais comercial, inclusive com o envolvimento de instituições como bancos comerciais em operações de microcrédito. Em contrapartida, muitas autoridades governamentais passaram a enxergar as microfinanças e os serviços por ela abarcados como ferramentas de desenvolvimento, capazes de proporcionar inclusão financeira e redução da pobreza.

Dadas as especificidades das operações de microcrédito, bem como as perspectivas para sua inclusão em estratégias e políticas públicas cujos objetivos são a promoção do desenvolvimento e a redução da pobreza, ganha importância a compreensão de como medidas de regulação e supervisão financeiras interferem no setor. Nesse sentido, a literatura especializada levanta hipóteses relativas aos efeitos de medidas regulatórias como adequação de capital, provisões contra inadimplência, exigências de capital de entrada e limites de juros, entre outras, sobre diferentes aspectos das instituições de microcrédito. São elencadas, dessa forma, quatro dimensões do setor de microcrédito, tidas como variáveis dependentes nesta análise. Tratam-se de sua estrutura em termos de número e de tipo de instituições, do alcance dessas instituições em relação ao total de clientes e a sua renda, da autossustentabilidade financeira apresentada pelas mesmas e, finalmente, da adimplência dos contratos de microcrédito.

No caso brasileiro, até os anos 1990, o setor de microcrédito encontrava-se pouco desenvolvido e sem qualquer tipo de regulação, com o predomínio da atuação de organizações sem fins lucrativos. A partir dos últimos anos da década, entretanto, o 
envolvimento do governo cresceu de forma significativa. Isso se deu tanto de forma direta, através da constituição do Programa Crediamigo do Banco do Nordeste do Brasil, e dos chamados Bancos do Povo, quanto de forma indireta, via debates no âmbito da Comunidade Solidária a respeito de quais seriam as melhores opções para o setor, inclusive como mecanismo de geração de renda.

Em consequência, foram constituídos novos modelos institucionais sob a forma de OSCIPs e de Sociedades de Crédito ao Microempreendedor, respectivamente sem e com fins lucrativos. Ao longo dos anos seguintes, uma série de medidas deu sequência a essas ações iniciais, remodelando o segmento de microcrédito brasileiro. Foram elas a imposição de exigibilidade de direcionamento de parcela dos depósitos à vista para operações de microcrédito, regulações no sentido de fomentar o crescimento e a atuação das cooperativas de crédito e, principalmente, o Programa de Microcrédito Produtivo Orientado.

Nesse processo, foram reformuladas as exigências de patrimônio líquido, de diversificação de riscos de limites de juros e de endividamento, entre outras, para as OSCIPs, SCMEPPs e mesmo para as cooperativas de crédito. Os resultados de tais alterações, no entanto, nem sempre foram os previstos pelas hipóteses levantadas na literatura. Para o caso brasileiro, aquelas que mostraram maior poder explicativo foram as referentes aos efeitos do alto patamar de exigência de patrimônio líquido, da flexibilização de restrições geográficas e populacionais de atuação, bem como previsões referentes a limites de juros. No entanto, mesmo para os resultados condizentes com as hipóteses elencadas, não é possível afirmar com absoluta certeza ter sido a medida regulatória adotada sua causa principal. Em alguns dos casos, isso se deve à percepção de descompassos entre os momentos em que foi adotada a norma regulatória e em que foram observados os resultados. Em termos mais gerais, adquire relevância a dificuldade de se controlar para outras variáveis explicativas.

No caso mexicano, as cajas populares atuaram por muitos anos sem qualquer tipo de regulação, consolidando-se como as principais fornecedoras de serviços de crédito e poupança no país. Seu crescimento se deu, até certo ponto, devido à ausência do setor bancário na concessão de tais serviços, dadas dificuldades enfrentadas nas décadas de 1980, em que o país se viu obrigado a decretar moratória e estatizou os bancos, e de 1990, em que o processo de reprivatização apresentou deficiências 
significativas, gerando concentração de propriedade bancária e contribuindo para uma nova crise econômica no país.

Assim, além das cajas populares, ao longo da década de 1990, multiplicaram-se outras instituições envolvidas nos setores de crédito e poupança, aproveitando a indisponibilidade de tais serviços para a maior parte da população e a ausência de regulação. Nesse contexto, surgiram também as primeiras iniciativas de microcrédito no país.

Foi somente a partir do ano de 2001 que o governo mexicano adotou medidas mais vigorosas no sentido de alterar essa situação. A promulgação da Ley de Ahorro e Crédito Popular (LACP) teve por objetivo unificar o conjunto de instituições que já concediam crédito de pequeno montante e ofereciam serviços de poupança em apenas dois modelos institucionais recém-criados, as sociedades financieras populares (SOFIPOs) e as sociedades cooperativas de ahorro y préstamo (SOCAPs).

Entretanto, surgiram empecilhos. Muitas das instituições abarcadas pela nova lei, em especial aquelas ligadas ao setor cooperativo, sentiram-se prejudicadas pela aplicação de uma única regulação, talhada para instituições com fins lucrativos, a modelos institucionais distintos. Nos anos subsequentes, a forte resistência encontrada resultou em inúmeros adiamentos na aplicação da LACP de forma completa, culminando em sua reforma no ano de 2009. Nesse novo cenário, as SOFIPOs tiveram seu marco regulatório mantido, passando este a ser aplicado também às novas sociedades financieras comunitarias (SOFINCOs). Em contrapartida, as SOCAPs passaram a ser reguladas pela Ley para Regular las Actividades de las Sociedades Cooperativas de Ahorro y Préstamo (LRASCAP).

Com essas e outras medidas regulatórias impostas pelo governo mexicano às instituições envolvidas com microcrédito no país, foram aplicadas uma série de medidas como exigências de diversificação e de capitalização por riscos, de coeficientes de liquidez, de capital de entrada, e de estruturação de modelos institucionais em níveis de operação. Tendo em vista as hipóteses elencadas na literatura, os resultados previstos nem sempre se concretizaram. No caso mexicano, mostraram certo poder explicativo medidas referentes a capital de entrada, diversificação de risco, coeficiente de liquidez e estrutura de níveis. Contudo, mesmo para os efeitos que estiveram de acordo com o previsto pela literatura, não existe a possibilidade de afirmar com absoluta certeza terem as medidas regulatórias consideradas variáveis explicativas sido sua causa principal. Em 
alguns casos, os resultados foram encontrados para um dos modelos institucionais analisados e não para outros, enquanto as dificuldades de se controlar para outras variáveis explicativas se mantiveram sempre presentes.

A regulação e a supervisão financeiras não são aplicáveis no vácuo, estando sujeitas a acontecimentos políticos, econômicos e sociais que certamente influem nos resultados finais das políticas adotadas. Desse modo, a ausência do setor bancário na concessão de crédito para a maior parte da população mexicana ao longo das décadas de 1980 e de 1990, com o setor público não sendo capaz de suprir a totalidade da demanda, certamente influiu na formação de um conjunto de instituições de pequeno porte e de cunho privado atuando no setor de microcrédito do país. Já no caso brasileiro, o crédito nunca se mostrou totalmente indisponível, mesmo em meio a crises. Apesar dos esforços governamentais em estimular a participação de instituições privadas na concessão de microcrédito, o setor público, especialmente na figura do Programa Crediamigo do Banco do Nordeste do Brasil, continua correspondendo a uma porção significativa do setor. O modelo de SCMEPPs, em especial, apresentou pouco desenvolvimento mesmo com a reformulação conduzida nos anos de 2007 e de 2008.

Assim, tanto no caso brasileiro quanto no mexicano, os tipos de regulação considerados variáveis dependentes pela literatura discutida mostraram poder explicativo limitado diante dos resultados encontrados na análise empírica. Obviamente não foi possível estabelecer qualquer tipo de relação causal, e mesmo a correlação verificada entre algumas das variáveis mostrou-se até certo ponto frágil, tendo em vista as dificuldades de se controlar para variáveis explicativas alternativas, em sua maioria fora do escopo desta pesquisa. Conclui-se, portanto, que a regulação e a supervisão financeiras são apenas dois dos fatores que influenciam na estrutura, no alcance, na autossustentabilidade financeira e na adimplência de portfólio no âmbito das microfinanças. Resta como desafio a construção de pontes entre a literatura aqui discutida e aquela que olha para outros elementos capazes de influenciar as microfinanças.

\section{Referências}

AHLIN, C; LIN, J; MAIO, M. Where Does Microfinance Flourish? Microfinance Institution Performance in Macroeconomic Context. Journal of Development Economics 95(2), 2011. pp.105-120. 
ALVES, J; AGUIAR, L; MROSS, C; PEREIRA, A. Massificação das Microfinanças no Brasil - Análise e Proposições. In: DODL, A; FELTRIM, L; VENTURA, E. (Eds). Perspectivas e Desafios para Inclusão Financeira no Brasil: Visão de Diferentes Atores. Brasília: Banco Central do Brasil, 2009. pp.83-98.

ALVES, S; SOARES, M. Microfinanças: democratização do crédito no Brasil, a atuação do Banco Central. 3 ed. rev. e ampliada. Brasília: BCB, 2006. 91p.

ARAÚJO, T; LIMA, R. Microcrédito Ontem e Hoje. In: CACCIAMALI, M. C; MATOS, F; MACAMBIRA, J. (Orgs). A Atividade e a Política de Microcrédito no Brasil. Fortaleza: Instituto de Desenvolvimento do Trabalho, USP, 2014. pp.35-53.

ARMENDÁRIZ, B; MORDUCH, J. The Economics of Microfinance. Cambridge, MIT Press. $2^{\text {a }}$ ed., 2010. 468p.

ARUN, T. Regulating for Development: The Case of Microfinance. The Quarterly Review of Economics and Finance 45, 2005. pp. 346-357.

ASSUMPÇÃO, C; CARDOSO, M; DARZÉ, A; FIORI, A; GOLDMARK, L. Entendendo a História das Microfinanças. In: ROCHA, A; MELLO, R (orgs). $O$ Desafio das Microfinanças. Rio de Janeiro: Mauad, 2004. pp. 9-139.

BACEN. Panorama do Microcrédito. Série Cidadania Financeira - Estudos sobre Educação, Proteção e Inclusão. Edição nº1. Jul. 2015, 41p.

BACEN. Atualização Mensal de Dados sobre Evolução do Sistema Financeiro. Disponível em: http://www.bcb.gov.br/?SFNATUALMES Acesso em: 21/11/2017.

BARONE, F; SADER, E. Acesso ao Crédito no Brasil: Evolução e Perspectivas. Revista de Administração Pública 42(6). Rio de Janeiro, 2008. pp.1249-1267. 
BARONE, F. ZOUAIN, D. Excertos sobre Política Pública de Acesso ao Crédito como Ferramenta de Combate à Pobreza e Inclusão Social: o Microcrédito na Era FHC. Revista de Administração Pública 41(2). Rio de Janeiro, 2007. pp. 369-380.

BAUCHET, J; MORDUCH, J. Selective Knowledge: Reporting Biases in Microfinance Data. Perspectives on Global Development and Technology 9, 2010. pp. 240-269.

BERENBACH, S; CHURCHILL, C. Regulation and Supervision of Microfinance Institutions - Experience from Latin America, Asia and Africa. USAID, Washington, 1997. $77 \mathrm{p}$.

BERGER, Marguerite. The Latin American Model of Microfinance. In: BERGER, M; GOLDMARK, L.; MILLER-SANABRIA, T. (Eds). An Inside View of Latin American Microfinance. Nova Iorque: Inter-American Development Bank, 2006. p.1-36.

BRASIL. Ministério do Trabalho e do Emprego. PNMPO - informações gerenciais do Programa Nacional de Microcrédito Produtivo Orientado. Disponível em: http://portalfat.mte.gov.br/programas-e-acoes-2/programa-nacional-do-microcreditoprodutivo-orientado-pnmpo/sistema-de-informacoes-do-pnmpo/ Acesso: 11/11/2017.

BRASIL. Lei nº 9.790, de 23 de março de 1999. D.O.U., 24/03/1999.

BRASIL. Medida Provisória nº. 802, de 27 de setembro de 2017. D.O.U., 28/09/2017.

BRASIL. Resolução no 3.109, de 24 de julho de 2003. D.O.U. 25/07/2003.

BRASIL. Banco Central do Brasil. Resolução no . 4.000, de 25 de agosto de 2011. D.O.U., 26/08/2011.

BRASIL. Banco Central do Brasil. Resolução nº 4.152, de 30 de outubro de 2012. D.O.U., 31/10/2012. 
CACCIAMALI, Maria; CHAHAD, José Paulo; TATEI, Fábio. Microfinanças e Política Pública na América Latina. Cadernos PROLAM/USP 8(1), 2008. pp.149-172.

CERVANTES, M; MONTOYA, M. The Bright and Dark Side of Microfinance. Centro Asia Pacífico, Working Paper Series, 2014. 36p.

CHOWDHURY, Anis. Microfinance as a Poverty Reduction Tool - A Critical Assessment DESA Working Paper ST/ESA/2009/DWP/89, 2009. 13p.

CHRISTEN, R. Commercialization and Mission Drift. The Transformation of Microfinance in Latin America. Washington, DC, CGAP, Occasional Paper (95), 2001. $24 \mathrm{p}$.

CHRISTEN, R. Microfinance in Latin America. Washington, DC, IDB. Seminar on Microfinance in China and Latin America, 2012. 29p.

CHRISTEN, R; LYMAN, T; ROSENBERG, R. Microfinance Consensus Guidelines: Guiding Principles on Regulation and Supervision of Microfinance. Washington, DC,CGAP/World Bank, 2003. 33p.

CHRISTEN, R. ROSENBERG, R. The Rush to Regulate: Legal Frameworks for Microfinance. CGAP Occasional Paper, no. 4.Washington, DC: CGAP, 2000. 24p.

COELHO, M.; PRANDINI, E. Programa Nacional de Microcrédito Produtivo e Orientado: Conquistas e Desafios. In: DODL, A; FELTRIM, L; VENTURA, E. (Eds). Perspectivas e Desafios para Inclusão Financeira no Brasil: Visão de Diferentes Atores. Brasília: Banco Central do Brasil, 2009. 254 p.

CONSTANZI, R. Microcrédito no Âmbito das Políticas Públicas de Trabalho e Renda. IPEA, Boletim de Mercado de Trabalho - Conjuntura e Análise 19, 2002. pp.21-25.

COSTA, F. Microcrédito no Brasil. IE/UNICAMP Texto para Discussão nº175, 2010. $29 \mathrm{p}$. 
COTLER, P. The Microfinance Sectors in Peru and in Mexico: Why have they followed different paths? IBERO, Ciudad de México. Documento de Trabajo, n.3 2011. 27p.

CNBV. Boletínes Estadísticos de Sociedades Cooperativas de Ahorro y Crédito. Em: http://portafoliodeinformacion.cnbv.gob.mx/eacp1/Paginas/boletines.aspx $\quad$ Acesso: $15 / 12 / 2017$

CNBV. Boletínes Estadísticos de Sociedades Financieras de Objeto Múltiple, Entidades Reguladas.

Em: http://portafoliodeinformacion.cnbv.gob.mx/SOFOLES/Paginas/bolestadis.aspx Acesso: $11 / 12 / 2017$

CNBV Boletínes Estadísticos de Sociedades Financieras Populares. Em: http://portafoliodeinformacion.cnbv.gob.mx/eacp1/Paginas/boletines.aspx Acesso: $12 / 12 / 2017$

CNBV. Boletínes Estadísticos de Uniones de Crédito. Em: http://portafoliodeinformacion.cnbv.gob.mx/oaacs1/Paginas/boletines_uc.aspx Acesso: $09 / 12 / 2017$

CUASQUER, H; MALDONADO, R. Microfinanzas y Microcrédito en Latinoamérica. Estudios de Caso: Colombia, Ecuador, El Salvador, México y Paraguay. Documentos de Discusión 2. Centro de Estudios Monetarios Latinoamericanos (ARBC), 2011. 48p.

CUEVAS, C. Enabling Environment and Microfinance Institutions: Lessons from Latin America. Journal of International Development 8(2), 1996. pp.195-209.

CULL, R; DEMIRGUÇ-KUNT, A. MORDUCH, J. Does Regulatory Supervision Curtail Microfinance Profitability and Outreach. The Wold Bank. Policy Research Working Paper 4748, 2009. 39 p. 
CULL, R; DEMIRGUÇ-KUNT, A. MORDUCH, J. Microfinance Trade-Offs: Regulation, Competition and Financing. In: ARMENDÁRIZ, B; LABIE, M. (Eds). The Handbook of Microfinance. Singapura: World Scientific Publishing Co. Pte. Ltd., 2011. pp. 153-155.

FELTRIM, L. Em Prol de um Sistema Financeiro Cada Vez Mais Inclusivo e Socialmente Justo. In: CACCIAMALI, M. C; MATOS, F; MACAMBIRA, J. (Orgs). A Atividade e a Política de Microcrédito no Brasil. Fortaleza: Instituto de Desenvolvimento do Trabalho, USP, 2014. pp.139-147.

FERNANDO, N. Micro Success Story? Transformation of Nongovernment Organizations into Regulated Financial Institutions. Asia Development Bank, Regional and Sustainable Development Department, 2004. 42p.

GALLARDO, J. A Framework for Regulating Microfinance Institutions: The Experience in Ghana and the Philippines. World Bank, 2001. 36p.

GALLARDO, J. Rural and Microfinance Institutions: Regulatory and Supervisory Issues. In: Financial Sector Assessment: A Handbook. Washington: World Bank, 2005. 460 p.

GARCIA, C. O Desenho do Programa Crediamigo do Banco do Nordeste. Fortaleza, Banco do Nordeste do Brasil. Série BNB Teses e Dissertações, 2010. 165p.

GÓIS, L; SILVA, R. As Diferentes Metodologias de Microcrédito no Mundo e no Brasil. Revista Tecnologia de Crédito Serasa, 2007. pp.11-30.

GREMAUD, A; TONETO JR., R. Microcrédito e o Financiamento Rural: Recomendações de Desenho e Gestão a partir da Experiência Mundial. Planejamento e Políticas Públicas 25, 2002. pp.89-104.

GUINNANE, T. The Early German Credit Cooperatives and Microfinance Organizations Today: Similarities and Differences. In: ARMENDÁRIZ, B; LABIE, M. 
(Eds). The Handbook of Microfinance. Singapura: World Scientific Publishing Co. Pte. Ltd., 2011. pp. 173-201.

GUTIÉRREZ-NIETO, B; MOLINERO, C. SERRANO-CINCA, C. Social and Financial Efficiency of Microfinance Institutions. In: ARMENDÁRIZ, B; LABIE, M. (Eds). The Handbook of Microfinance. Singapura: World Scientific Publishing Co. Pte. Ltd., 2011. pp. 397-418.

HARTARSKA, V. Governance and Performance of Microfinance Institutions in Central and Eastern Europe and the Newly Independent States. World Development 33 (10), 2005. pp. 1627-1643.

HARTARSKA, V; NADOLNYAK, D. Do Regulated Microfinance Institutions Achieve Better Sustainability and Outreach? Cross-Country Evidence. Applied Economics 39(10-12), 2007. pp. 1207-1222.

HELMS, B. Access for all. Building Inclusive Financial Systems. Washington: CGAP, World Bank., 2006. 170p.

HELMS, B. REILLE, X. Interest Rate Ceilings and Microfinance: The Story so Far. CGAP Occasional Paper 9.Washington, DC: CGAP, 2004. 19p.

HERMES, N; MEESTERS, A. The Performance of Microfinance Institutions: Do Macro Conditions Matter?. In: ARMENDÁRIZ, B; LABIE, M. (Eds). The Handbook of Microfinance. Singapura: World Scientific Publishing Co. Pte. Ltd., 2011. pp.173-201.

HERMES, N; LENSINK, R; MEESTERS, A. Financial Development and the Efficiency of Microfinance Institutions. 2009. 29p. Disponível em: https://ssrn.com/abstract $=1396202$

HERMES, N; LENSINK, R; MEESTERS, A. Outreach and the Efficiency of Microfinance Institutions. World Development 39(6), 2011. pp. 938-948. 
HERNANDEZ, C. ¿De verdad están las instituciones de microfinanzas dando atención a los pobres? in Pérez Lechuga, Venegas Martínez y Martínez Sánchez. Modelos para la toma de decisiones en la Ingeniería Económica y Financiera: Un enfoque estocástico, Centro e Investigación Avanzado en Finanzas de la Universidad Autónoma del Estado de Hidalgo. 2014. 29p.

HERRERA, J. Cooperativas de ahorro y préstamo en México: De la ausencia al exceso de regulación. MBS, jul. 2012, (2): pp.67-86.

JANSSON, T; WENNER, M. Financial Regulation and its Significance for Microfinance in Latin America and the Caribbean. 1998. 51p. Disponível em: SSRN: https://ssrn.com/abstract=102523

LUTZENKIRCHEN, C; SPEYER, B; WEISTROFFER, C, Microfinance in Evolution: an Industry between Crisis and Advancement. Deutsche Bank Research, 2012. 18p.

MARTINEZ, H.E. Situación Actual del Sistema de Ahorro y Crédito Popular en México. Revista Latinoamericana de Economía, Vol.39, n.152. 2008. p. 167.

MARULANDA CONSULTORES; DAI MÉXICO. Estudio Microfinanzas en México. 2011. 58p.

MENDOZA, R; VICK, B. From Revolution to Evolution: Charting the Main Features of Microfinance Perspectives on Global Development and Technology 9, 2010. pp. 545580.

MERSLAND, R; STROM, R. Performance and Tradeoffs in Microfinance Organisations - Does Ownership Matter? Journal of International Development 20, 2008. pp. 598-612.

MERSLAND, R; STROM, R. Performance and Governance in Microfinance Institutions. Journal of Banking and Finance 33, 2009. pp. 662-669. 
MIGUEL, A. Política de Microcrédito no Governo Lula: a constituição de um mercado de microfinanças via política pública. In: 35 Encontro Anual da ANPOCS, 2011, Caxambu. $35^{\circ}$ Encontro Anual da ANPOCS, 2011. 22p.

MIRANDA, R. Desarrollo del sector microfinanciero en México: indicadores profundidad y amplitud 1996-2012. Revista Mexicana de Ciencias Agrícolas, Vol 6 (01), 2015. pp. 19-31.

MONZONI, M. Impacto em Renda do Microcrédito. Tese de Doutorado em Administração Pública e Governo apresentada à FGV/Escola de Administração de Empresas de São Paulo. São Paulo, FGV, 2006. 194p.

MUCIÑO, M. Cooperativas de Ahorro y Crédito en México. Boletín de la Asociación Internacional de Derecho Cooperativo, n.49. Bilbao, 2015. pp. 49-63

NERI, Marcelo Caetano. Microcrédito: O Mistério Nordestino e o Grameen Brasileiro - Perfil e Performance dos Clientes do Crediamigo. Rio de Janeiro: FGV, 2008. 375p.

NETO, R. Sociedades de Crédito ao Microempreendedor e à Empresa de Pequeno Porte: História e Perspectiva. In: DODL, A; FELTRIM, L; VENTURA, E. (Eds). Perspectivas e Desafios para Inclusão Financeira no Brasil: Visão de Diferentes Atores. Brasília: Banco Central do Brasil, 2009. pp.133-147.

NICHTER, S; GOLDMARK, L; FIORI, A. Understanding Microfinance in the Brazilian Context. Rio de Janeiro, Programa de Desenvolvimento Institucional, BNDES. 2002. 59p.

OLIVARES-POLANCO, F. Commercializing Microfinance and Deepening Outreach? Empirical Evidence from Latin America. Journal of Microfinance / ESR Review 7 (2), 2005. pp. 47-69. 
OLSEN, T. New Actor in Microfinance Lending: The Role of Regulation and Competition in Latin America. Perspectives on Global Development and Technology 9, 2010. pp. 500-519.

PEREIRA, A. Programa Nacional de Microcrédito Produtivo Orientado - (PNMPO): Descrição, Resultados e Perspectivas. Banco Central do Brasil; Programa Nacional de Microcrédito Produtivo Orientado - MTE, 2007. 21p.

PEREZ-SOTO, F. Las Sociedades de Ahorr y Crédito Popular en México. In: F. Rérez, E. Figueroa, L. Godínez (eds.) Matemáticas Aplicadas. Handbook T-I. -CEECORFAN, Texcoco de Mora-México, 2016. pp.145-156

RIBEIRO, C; CARVALHO, C.E. Do Microcrédito às Microfinanças - Desempenho Financeiro, Dependência de Subsídios e Fontes de Financiamento. São Paulo, Editora PUCSP EDUC, 2006. 210p.

ROODMAN, David. Think Again - Microfinance. Foreign Policy, Fev. 2012. Disponível em: http://foreignpolicy.com/2012/02/01/think-again-microfinance/ Acesso em 05/08/2017.

ROSALES, Ramón. Regulation and Supervision of Microcredit in Latin America. In: BERGER, M; GOLDMARK, L.; MILLER-SANABRIA, T. (Eds). An Inside View of Latin American Microfinance. Nova Iorque: Inter-American Development Bank, 2006. pp. 109-143.

ROSENBERG, R. Reflections on the Compartamos Initial Public Offering: A Case Study on Interest Rates and Profits. Washington, CGAP/World Bank, Focus Note $\mathrm{n}^{\mathbf{0}} \mathbf{4 2}$, 2007. 20p.

SANTOS, C.A. O Microcrédito e a Formalização de Micronegócios: Desafios e Perspectivas no Brasil. In: CACCIAMALI, M. C; MATOS, F; MACAMBIRA, J. (Orgs). A Atividade e a Política de Microcrédito no Brasil. Fortaleza: Instituto de Desenvolvimento do Trabalho, USP, 2014. pp.125-138. 
SHCP. Disposiciones de Carácter General Aplicables a las Actividades de las Sociedades Cooperativas de Ahorro y Préstamo. D.O.F. 04/06/2012.

SHCP. Disposiciones de Carácter General Aplicables a las Entidades de Ahorro y Crédito Popular, Organismos de Integración, Sociedades Financieras Comunitarias y Organismos de Integración Financiera Rural, a que se Refiere la Ley de Ahorro y Crédito Popular. D.O.F. 18/12/2006.

SHCP. Disposiciones de Carácter General Aplicabes a los Almacenes Generales de Depósito, Casas de Cambio, Uniones de Crédito y Sociedades Financieras de Objeto Múltiple Reguladas. D.O.F. 19/01/2009.

STIGLER, G. The economic theory of regulation, Bell Journal of Economics and Management Science 2, 1971. pp. 3-21.

TCHAKOUTE-TCHUIGOUA, H. Is There a Difference in Performance by the Legal Status of Microfinance Institutions?. The Quarterly Review of Economics and Finance 50, 2010. pp. 436-442.

TRUJILLO, V. Microfinanzas em América Latina y el Caribe: el sector en cifras 2013. Washington, DC: Fondo Multilateral de Inversiones, 2013. 20p.

VANROOSE, A. Differences in the Development of the Latin American Microfinance Market: Identifying Reasons. Investment, Management and Financial Innovations 7(3), 2010. pp.41-53.

VANROOSE, A; D'ESPALLIER, B. Microfinance and financial sector development. Université Libre de Bruxelles. CEB Working Paper 9(40), 2009. 40p.

ZARATE, M. Las microfinanzas en México, um acercamiento. Ciencia Administrativa, 2010-1. pp.47-53. 